Historic, archived document

Do not assume content reflects current scientific knowledge, policies, or practices. 

U. S. DEPARTMENT OF AGRICULTURE, BUREAU OF ENTOMOLOGY - BULLETIN No. 70.

L. O. HOWARD, Entomologist and Chief of Bureau.

\title{
REPORT OF THE MEETING
}

\author{
OF
}

\section{INSPECTORS OF APIARIES,}

SAN ANTONIO, TEX., NOVEIBER 12, 1906.

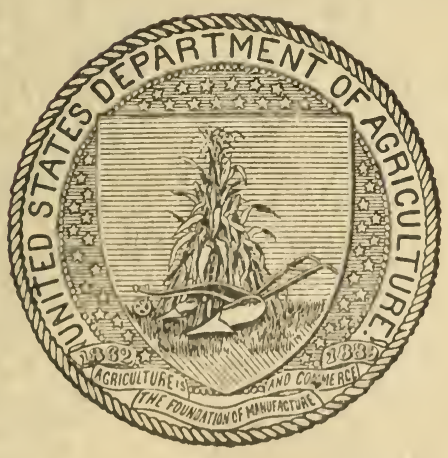

WASHINGTON:

GOV ERNMENT PIINING OFFICE.

1907 . 




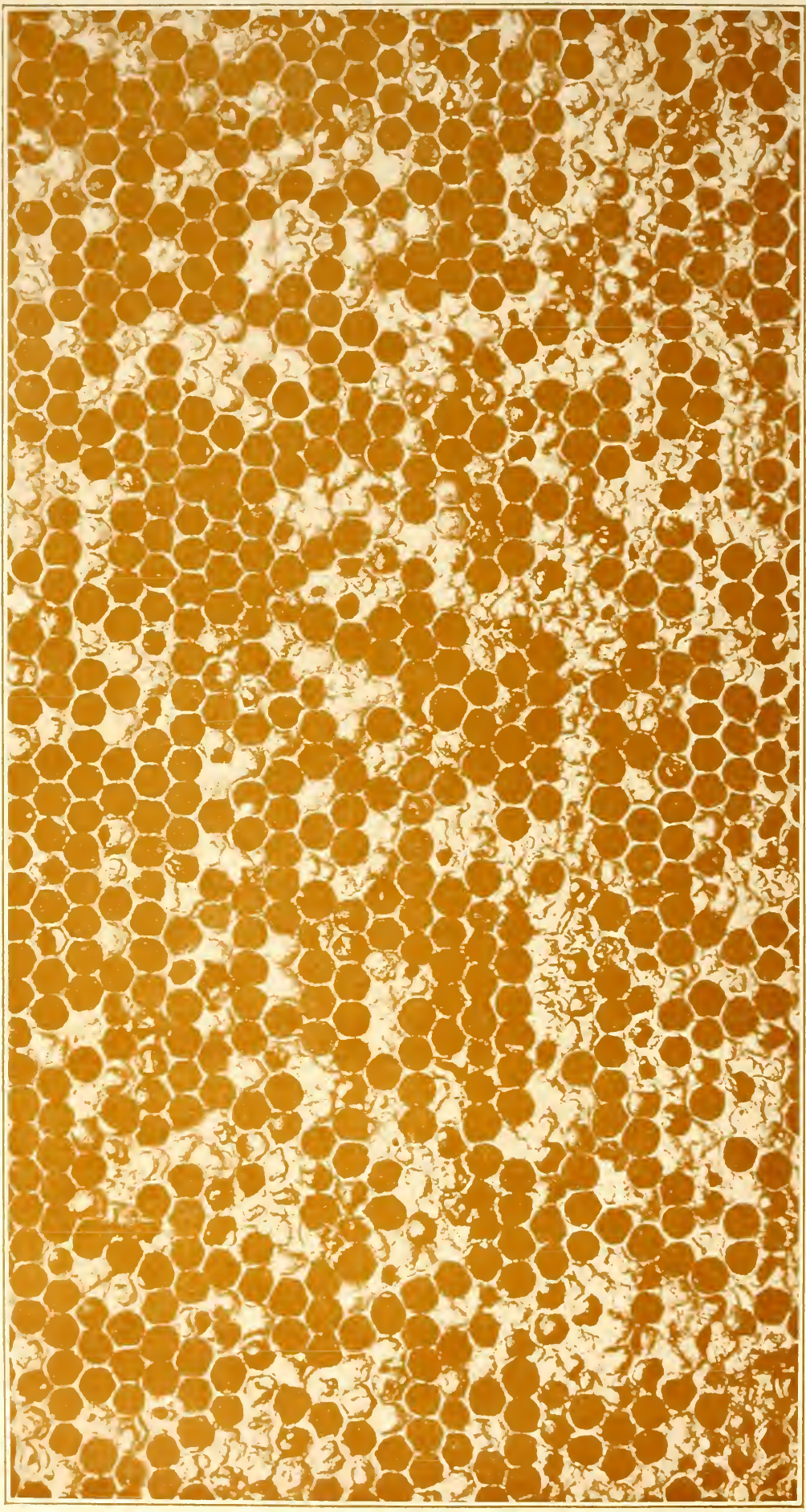




\title{
U. S. DEPARTMENT OF AGRICULTURE,
} BUREAU OF ENTOMOLOGY - BULLETIN No. 70.

L. O. HOWARD, Entomologist and Chief of Bureau.

\section{REPORT OF THE MEETING}

\author{
$\mathrm{OF}$
}

\section{INSPECTORS OF APIARIES,}

SAN ANTONIO, TEX., NOVEMBER 1:, 1906.

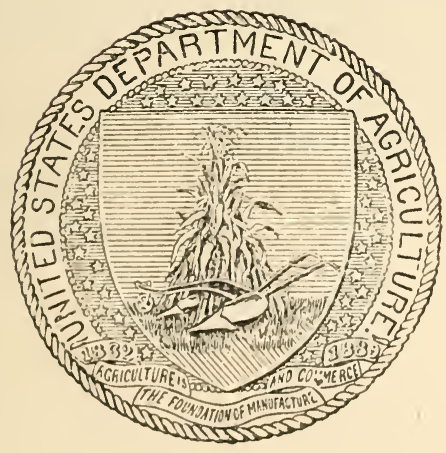

WASHINGTON:

GOVERNAENT IRINTING OFFICE. 


\section{BLREAL OF ENTOMOLOGY.}

L. O. Howard, Entomologist and C'hicf of Bureau.

C. L. Marlatt. Entomologist and Acting Chief in absener of chief.

R. S. C'liftox. ('hief C'lerk.

F. H. Chittexdex, in charge of breeding experiments.

A. D. Hopkixs, in charge of forest insect inestigations.

W. D. Huxter, in charge of cotton boll weeril investigations.

F. MI. WeBster. in charge of cereal and forage-plant insect inrestigatiuns.

A. L. Quantance, in charge of deciduons-fruit insect incestigations.

I. M. Rogers, in rharge of gipsy and broun-tail moth arork.

A. W. Morril.t. engaged in white fly inrestigations.

E. S. G. Tites, in charge of gipsy moth laboratory.

C. J. Gillass, engaged in silli incestigations.

R. I'. C'urrie, assistant in charge of editorial work.

Mabel Colcond, librarian.

\section{A picultural iniestigations.}

E. F. Phillips, in charge.

(i. F. White, rexpert in bacteriology.

J. M. Raxkix, in charge of apricultural station, Chior, Cal.

F. G. Fox, assistant in apiary.

I. N. Gates, rollaborator. Woreester. Mass.

JESSIE L. MARKS, apicultural clerti. 


\title{
LETTIR ()E: TR ANSWITTAI.
}

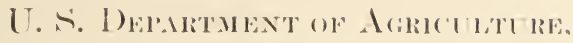

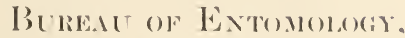

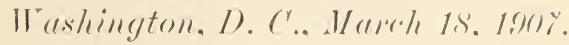

Sir: I have the honor to transmit the manuseript of the proceeding of a meeting of inspertors of appiaries held in Fan Antonio. 'Tex., November 12, 1906. The meeting together and conference of the persons interested in the eradication of the discases which are sureh a drawback to apiculture can not fail to bring ont many pointe of importance. In such a meeting the subject is presented in a way which is not possible in articles written for jonruals devoted to bee kepping or for publication in other forms. There is no oroanization of in-pectors and no funds are available by which these proceeding may be published. and since this necting was to a large extent the result of the efforts of members of the Burean of Entomologra and sincer these men took such an active part in the meeting. it would seenis fitting that the proceedings be issued as a publication of the I0epart-

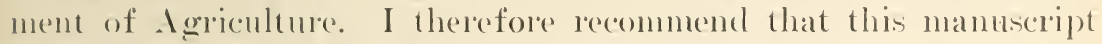
be publisherl as Bulletin No. 70 of this Burau.

liespectully.

L. (). II()W:IR!),

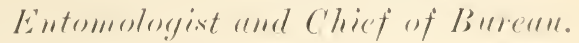

HoH. J.1.M WIIsox.

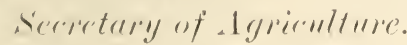





\section{PRI:I:ICE.}

The meeting of inspectors of appiaries was held on the Monclay following the elose of the National Bee Keepers Ascociation convention. Norember 12. 1906, at san Intonio, Tex., as a result of a call issued by Mr. N. E. France, inspector of aptaries for Wiseonsin, Mr. W\%. Hutchinson. inspector of apiaries for Michigan, and the writer.

The object of this meeting was to get together for consultation the men interested in the eradieation and control of bee diseases. The closer cooperation of these men in their work can result only in good to apiculture and is greatly to be desired. Inspectors are chowen from among the practical bee men of the county or state and the majority of them are familiar with their work on entering the service. They also accumulate a vast amount of information concerning diseases, most of which never reaches the bee jommals or gains publicity in any way. I meeting of these men brings out many points which would otherwise remain unknown.

The meeting at San Antonio was most interesting and valuable, and since much that was said there has never been published it seems decirable to issue the proceedings of the meeting in the form of a bulletin to add to the knowledge of the bee-keeping public on bee diseases.

At the clowe of the meeting the writer was asked by the inspectors present to prepare a list of questions based on the laws now in force for the control of hee diseases. This list was prepared at once and a copy sent to each of the inspectors whose name and address conld be obtained. At the same time the prestions were taken up for detailed examination, and rarions perons were consulted on points of importance which arise. This work is not yet complete. for it has assmmed proportions which were entirely mexpected at the beginning. It was originally intended that this discussion of the laws should be inserted as an appendix to the present report, but this would only delay the present publication. This aspeet of the subject may therefore be submitted for future publication as soon as it can be prepared. It is very important that the best posibible wording be weed in a law to control bee diseases. The bee keepers of several states which do not have such laws are at present interested in this subject. 
In the preparation of the manuscript for publication it was necessary to rewrite the articles by Doctor White and the present writer because the mamner of presentation of these subjects in a meeting is not suited for publication. It was aloo necersary to edit the discussions, for the senographic report was inacenate in numeroms places. It is believed. howerer. that even if the exact words of each perton are not recorded. the meaning is the same as was intended to be conreyed. In certain places it has seemed desirable to enlarge somewhat on certain thing, which were said by the writer. This bulletin therefore can not be called a verbatim report, but it represents neverthele-the proceedings of the meeting.

It is hoped that similar meetings may be held in the future.

E. F. Phillims. In cherege of 1 priculture. 


\section{CONTEXTS.}

PAPERS.

The Bacteriology of liee Diseases

(i. F. While

Page.

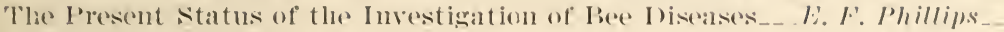
Apiary Inspertion in New York State ('has. stematt American Fonl Brood on the Pacific coast The IIstory of Hee-I)isease Inspertion in Wisconsin _. 1. F. France

Symptoms of bee diseases

Geographlical distribntion

('ompan rison of diseases.-.

Infertion in loney._._._.

Infection of larvie

Barteria in yueens

" Black brood"

Infection carried to Howers

Vitality of spores

Inblications on bee diseases

Fxistence of Amerian fonl brood and European foul brood in the same (colony

(ieographical distribution of American foul brood

Effect of elimate on virulence

Association of inspectors of apiaries

Treatment for bee diseases

Effect of requeening on disease

Medic:ation _-

Expense of treatment ...

boiling honey from diseased colonies.

\section{IILUSTRATION.}

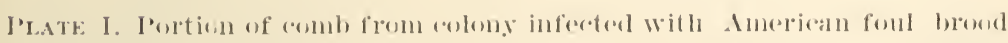





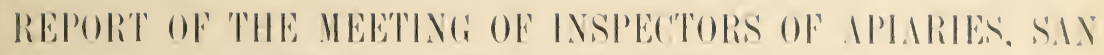 ANTONIO, TEX., NOVEMBER 1:, i!nti.}

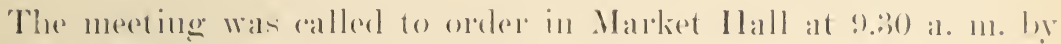
!)r. E. F. Phillips. of the Burean of Eutomologer. Department of

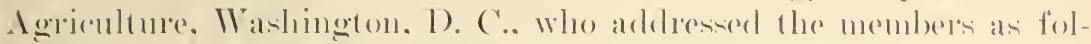
lows:

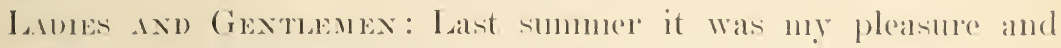
privilege to visit a eonsiderable number of the men at work on beedisease inspection throughout the United States. Ifter talking with them and going with them on inspection trip)s, it became evident that there is a great deal yet to be done in regard to the making of better methods of inspection in work against bee diseases. entirely apart from the seientific aspect of the subject.

On the 30 of last August Mr. X. E. France, inspector of apiaries for Wrisconsin, who is attending this meeting, and Mr. Wr. Z. Hutchinson. the inspector of apiaries for Michigan, and myself met in Milwankee, Wis.. to talk over certain plans for making bee-clisease in-pecion more effective. A cirgular letter. addresised to the persons now atede as inspectors in the varions connties and states of the fuited States. Was drawn 11 p. sngegest ing that they meet in some place this fall to take np) the work of bringing about more nuformity in the methods employed. The meeting of to-day is the result of that rirenlar letter.

There are sereral things in work against bee diseases that are not at all rear to the bee-disease inspector's and other's interested in the subject. and we wish to take some of them up for discrlscion to-day. We have with us I)r. (x. F. White, of the Burean of Animal !nclustry. U. . Department of A griculture. Washingtem, I). ('.. who has made a most thorongh scientific sturly of the cantse of hee discases. and we thall first ask him to give his demonstrations and the result of his worle. After he finishes I shall myelf attempt to smmmarize the investigations of bee diseases which have previonsly been made by different men. It is perhaps well to talie nu the scientific atspect of this work first in order to make this cleare, and hater we shall take up the methods of inspection and treatment and the form of desirable laws rontrolling bee diseases. 
It would perhaps be well for the inspectors of apiaries in the Inited states to be organized in some way so that there might be greater uniformity in the work and more harmonious cooperation. In lintlialo several vears ago such an association was organized. At that time Mr. France, Mrr. Hutchinson, and sereral others met together and organized an association of bee inspectors of the Inited sitates and Canada, but they had only an organization meeting and have nerer met since. Such an organization is desirable, but perhap: not all of those that would care to take part in the association are present.

1)octor White will now give us a demonstration on the brood diseases of bees. a subject on which he has made exhaustive studies.

\section{THE BACTERIOLOGY OF BEE DISEASES. ${ }^{a}$}

Isy (‥ F. WHITE. I'll. D.,

of the I. s. Isepurtuent of Alyriculture.

The object of this paper is to discuss briefly the science of bacteriology as it is used in the study of bee diseases and to give a summary of the results of my work on these diseased conditions.

In our discussion of bacteriology, or the science which deals with bacteria, it may be well to consider the subject under the following hea dings: (1) The nature of bacteria; (2) their distribution; (3) the methods for studying them, and $(t)$ the results of their activity.

THE NATURE OF BACTERIA.

Bacteria are considered by some scientists to be a form of life lower than either animals or plants, but by the majority of authorthey are looked upon as plants, and we shall so consider them at this time without going into a detailed discussion of the arguments in favor of such a view. Bacteria, often referred to as germs. microbes. or parasites, are, then, very small plants, so small indeed that they must be magnified foo diameter's or more before they can be seen.

a At the merting of the inspertors of apiaries Doctor White gave a demonstration of the work which he has done on the brood diseases of bees. showing. in illustration of his adhess, slides and cultures of the val'ious bacterial under consideration. In view of this fact the stenggraphice report of his address is not wear on all points, since the demonstrations are larking. It has, therefore. seremed best for Inoctor White to write the article here published, giving a fminlar disemssion of this plase of the work which would be intelligrible without the demenstration. The substance of his remarls is all included in this paper exerent the part pertaining to the work of other bacteriologists, which is dwelt (on at some lenertle in the article leerein published on "The I'resent status of riec I isease Investigation." This methed of liandling the subject in a published report will milke the subject much clearer to those who did not attend the meeting at San Antonio,-E. F. P. 


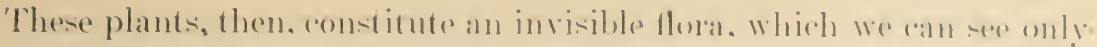
by the ste of a microscope of very high matrifye power. The morphologry, or the structure. including form and sime is primcipally

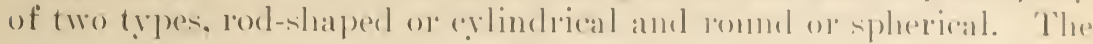
size of bacteria varies. Those which are roct-shaper manally meastre

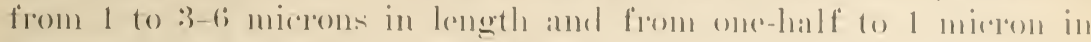
diameter. I mieron is the min of measme for very small objects and is equivalent to 25000 of an inch. For examples if a single bate-

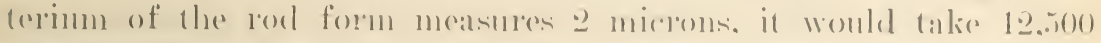

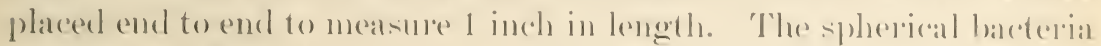
or coced have about the same diametere as the rod-shapeel ones.

Bacteria giow or multiply after a mamner callect fission: that is. after increasing in size they berone conetrieter in the midelle. which constrietion finally serers the rod completely, and we then hat we two bareteria where there was hut one before. Conder favolable anditions for growth. each bacterium clivides by fiscion erery twenty minntes. or, in other workts, gives rise to three generations in one hour. sureh being their marvelous late of incerase, a little calculation will denonstrate that countless millions may be formed in a short time moncles favorable conditions, which are proper temperature, moisture, fool in correct proportions, and the absence of much light. The temperatture most favorable for the growth of a species of bacteria which is able to produce a diseased conclition in animals is approximately the temperature of the animal which is affected by such species. Moisture is universally necessary. 'The food inust not be too encentrated. Light inhibits the growth of bacteria. I)irect sunlight is bactericidal; that is, it kills bacteria.

Many species produce spores when the conditions are not favolable for the multiplication of bacteria. There are small bodies formed in the bacteria (probably nerer more than one in a single batcterimm) which are somewhat comparable to the grain in wheat and rolm. These spores constitute a resting stage and usually also a very resistant stage. for high temperature and strong disinfectant solutions are necessary to kill them. It is these spores which probably make the control of the bee diseases nore difficult. When the spores a gain gain acces to a suitable "soil." for example, the body of an animal. they" germinate and a new growth takes place as before.

Many species of hacteria have the power to move when they are in a liquid medimm. while other's do not. This ability to move is due to

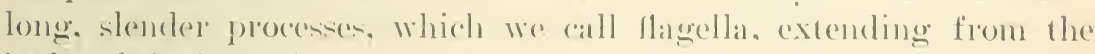
body of the bacterimm.

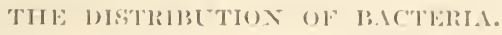

Bacteria are very widely distributed. Everyone is familiar with the very wide distribution of the higher members of the plant king- 
dom, as the trees. shruh.. flower's, and grasses. and we may for convenience refere to the plants as the visible flora. There is also an invisible flora. marle up of the plants we can not see except with the aid of the miscrope. This flora inchudes the very minute plants referred to as hacteria, and also the yeasts and some fungi. The distinct species of plants which belong to the invisible flora outnumber hy far those which are visible to the naked eye. These microseopic plants are found upon the surface of the animal body and along the digestive tract: they are found in the soil, in the food we eat, and in the water and milk we drink, but are not found within the normal tissues of animals and higher plants.

\section{IIOW B.ICTERIA ARE STTDIED.}

The morphology or' structure of bacteria is studied with the aid of a microcope of high magnification. Since the number of distinct species of bacteria is so extremely large, and since the shapes assumed by them are so few, it is obvious that many different kinds must look alike mater the microscope. This is a point of considerable value in connection with bee-disease work. since in some cases attempts have been made by the use of the microscope alone to determine what species of bacteria was causing certain diseased conditions. With our present knowledge it is not possible to make a positive diagnosis of these diseases with the microscope alone. With the microscope we are able to determine ustually only the genus to which any bacterium belongs. If we are trying to identify Bacillus alcei, for example, we are able with the microscope alone to say only that it is a Bacillus. since it is seen to be a straight rod. Some otlier means is necessary to determine the species (atrei) to which it belongs. For this purpose we use artificial media or ". soils" in which pure cultures of the hacteriat are inoculated or planted.

The media in common use are boullon and sugar-free bouillon. gelatin. agar, and sugar-free bouillon to which has been added small amounts of various sugars known in chemistry as glucose. lactose. saccharose, maltose, and levulose. In addition to these media. use is made of potato. milk. and milk to which litmus has been added. so that the reaction-whether atcid. alkaline. or nentral-may be noted. The bouillon is prepared from beef juice to which some peptone and salt are atcled. Fugar-free bouillon is similar, except that the muscle - matr has been remored. Gelatin is made from pure sheets of gedatin somewhat similar to that used in cooking. to which bonillon is adkext. 'The bonillon aftores the food for the bacteria or other' small plants. while the gelatin liecps the medium solid at ordinary tempera-

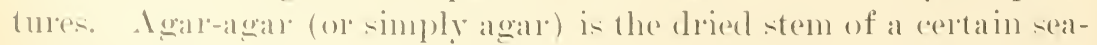
weed which liquefies on heating: to this is added boullon, as in the 


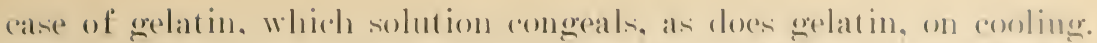

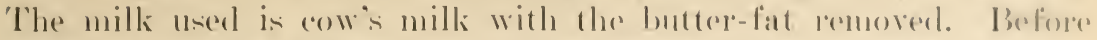
using, all these merlia alre sterilized by heat to kill all bacteria or fungi which might be perent.

Having prepared these soils in this way. before the ineroulation of them the bacteria must be obtained in pure culture. by pure culture is meant the growth of ons species only in a medimm. Finele a collture is obtained by diluting a small guantity of the material. (2. e.. decayed larvas, containing the bacteria with a relatively latge amomut of liquefied agar, and then pouring it into a shallow sterile grass hox (Petri dish). In this way we get only a few hacterial sattered thromghont a thin layer of the medimm. Eated hacterimm then begins to grow, and after a fow hours it has produced a large mumber, which, heing massed together, we are able to see with the naked eye. This mass of bacteria, having been produced from ono individual, constitutes a colony, and such a colony can contain but one sjecies, therefore we speak of it as pure. Pure cultures are them mate by inoculations from such a colony. The next step is to identfy this species which we now have isolated from all other' species. To do this we inoculate a few or all of the differential meclia mentioned above. Ifter inoculating and growing the bacteria in these diflerent media or soils at about the body temperature for a day or longer we observe the effect mpon the rarions media produced by the growth of the bacteria and the appearance of the growth in or npon these media. All these phenomena and appearances we speak of as cultural characters. Having obtained in this way the cultural characters of a species of bacteria, we are able to classify it by comparing these cultural characters with the cultural characters of known species.

To illustrate this, let us take for example Bacillus coli commumis, found normally in the intestine of man and many animals, including the intestine of the athlt bee. Barrillus alvei. found in European fonl hrood, and Bacillus lareer. found in American foul inood. Bacillus coli commenmis by its growth in bouillon anuses the latter to become heavily clomeded: Bacillus aleci makes it feobly chomeded; while Bacillus larea does not grow at all in this soil and the bonillon remains clear. In gelatin barillus coli ammunis garows very well and does not liquefy the medium hy its growth; Bareillus al erei garows very slowly and only ferbly and liquefies the gelatin: while burillus

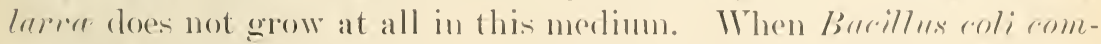
memis is planted on potato it produces a bowni-h erowth; Barillus alief on this medium produces a lemon-yollow growth, and Barit-

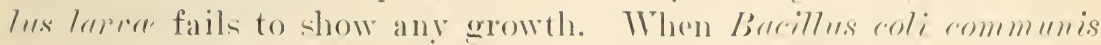
is planted in milk there follows a rapid somping of the milk and a firm coagulation of the casein; Bacillus aldei produces a soft coagu- 
lum which is follower by a sow diege-tion or lipuefaction of the

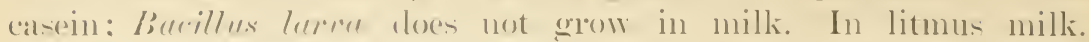

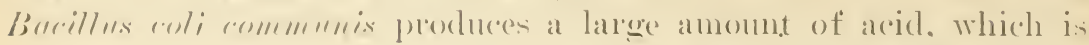

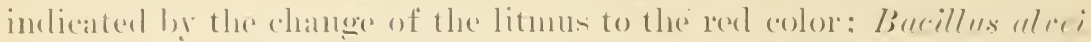

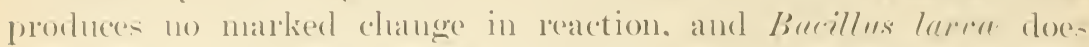
not grow in this medimm. In the bouillons to which the sugars,

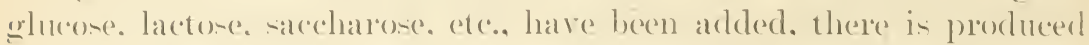

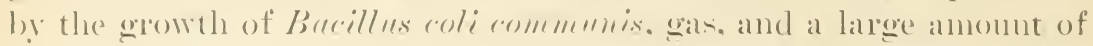
alcid: Bucillus aleci does not produce was and only a small amoment of acid by its growth in the media containing sngar's. While Bucillus laner does not grow when planted in these " soils." (I shall speak later of a medium upon which Bberillus larea will grow.)

It is by these differences which we observe in the growth upon the various media and the effect produced upon the different media by the growth of the bacteria that we are able to determine one species of bateria from another.

THE IRELLTS OF THE AC"TIVTY OF B.IC"TERIA.

In the consideration of this question it is convenient to divide the bacterial flora into two groups-nonpathogenic. or those which do not produce disease, and pathogenice, or those which do produce diseatese. some of the nompathogenic bacteria are economically rery important as scarenger's. The bodies of dead animals and plants are largely bronght to decar by them. The flavors of butter, cheere, and wineare thought to be inproved by the growth of bateria or other microorganisms-the fungi and the yeasts. Others of these micro-organisms ruin the food, causing the somring of milk, the spoiling of fruit. ete. Many discases in man and animals are known to be callsed by bacteria, as tuberculosis, diphtheria. glander's, and ąnthrax.

I wish now to speak briefly of how bacteriology has been used in the study of bee diseases. and to smmmarize the results which have heen obtained. For a more detailed aceount your are referred to a billetin ismed by the Bureau of Entomology of the United stateDepartment of Agriculture-Technical serien. No. 1t, " The IBateria of the Apiary. with special Reference to Bee Diseases," issued Norember (i. 19)ot.

From what has been sald one would naturally infer that in every apiary. whether di-eased or not, there are on the hives. combs. and bere a large number of bacteria that are perfectly harmless. If one in trying to tius in a diseased appiary the species of bacteria which is the probable cause of the trouble. what is the method of procedure? silppere there were two herds of attle on adjoining farms and the attle on one fandm were dying while the-e on the other remained well. If' it were-nepeeterl that come plant which the cattle were eat ing wasthe 
canse of death. Hatmally the plant womlel be selected which wa. found on the farm where the animals were sirele and which was mot found on the farm where the animals enmainsel well. This is exactly the kind of reasoming used when we are losking for the bacteria which ale cansing the diseases amomeg hees. 'This meres-

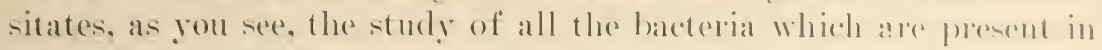
any apiary, whether eliseased or not, as well as those in diseased apiaries.

It the time we began the work on bee diseases, in .Jume. 1!)(t). the disorelers which were causing the greatest tromble were kinown to

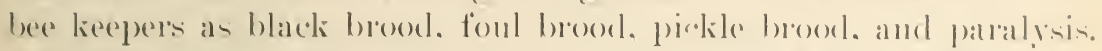
Ifter the study of a larege number of samples of hood aflectod ly disease which was being alled black hood and the finding of Bareillus alrei in all of them, it is very clear that this discases is the same as that investigated by Cheyne in 1ss.) and alled hy him

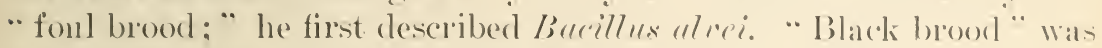
a name given by I)r. William R. IIowaled, of Fort Worth, 'Tex.e to a disease which he thought existed in New York state, and he deseriber as its cause Bucillus milii. After a careful seareh in Nerre lork siate for a disease containing Bucillus milii we were mable to find it, and there seems to be no ground for the rlescription of a new disease. What has been called hlack brood hy Doctor Howarel is olvionsly the type of foul hrood which we now distinguista as Emopean fonl boorl.

In the decaring lave and dried seales fommel in the cells in the disease which was receiving the name of foul hrood there were seen by the use of the microscope a very large number of the spoles of barteria, and in the larvas in the early stage of the disease there were observed bacteria in the rod form. When these spores were planted upon the media or soils which have been explained andier in this paper, they would not grow. It became necessary, then, to devise a soil in which the growth eould be obtained. Ifter a $111 m$ mer of 111 successful attempts, a medimm or soil was made from houlthy bee larve in which the spores would germinate and the batederia wombl

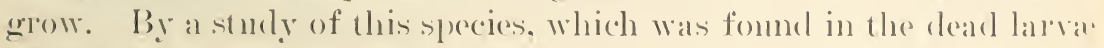
of this disease and which was not found in the healthy apiary, it was

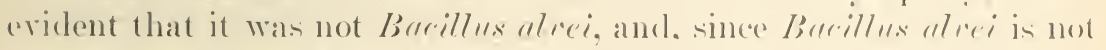
present at all. we know that this discase is not the fonl hrood which Cheyne had reported in his work in 185.). vince it is not this type of foul brood. what could it be! By calefully leviewing all the work which had been done by others.the oonclusion was inevitable that this diseased condition had not been described properly flom a bacterial standpoint as a disease separate and distinct fiom the fonl hrood of Cheyne, but that the mistalie had been made for a long time of alling two different and distinct diseases which aflected the brood of bere: by one name. 'This condition Was reported to the New Iork vilate 


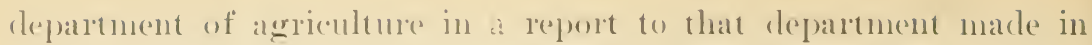
Jamuary, 190:). and another in Jamuar. 1!104. In the latter report this andition. for want of definite information. Was reforered to as

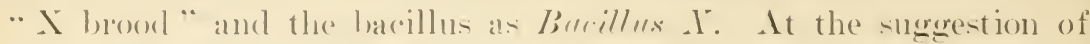
I)r. F. F. Phillips. of the Bureatr of Entomolory. Inited sitates I) partment of Igriculture. it was thought best for very good reasoms to retain the nime foul hroot in the name of arah disease and add a qualifying wored to designate the difference between the two

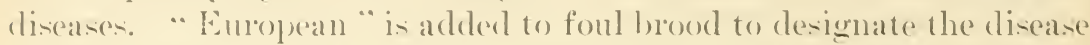

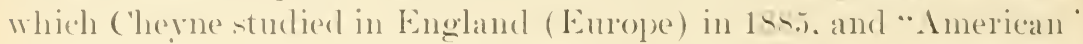
is added to the foul hroorl which was first -tudied in the frited states (America). Wo distinguish. then. European foul horod and American foul brood. Both of these di-eases of the broorl of hees seem to he found in Enrope as well as America. It must therefore le rementbered that these names do not put any stigma on either comntry. Europe or America. but. on the contrary. Europe is thereby given the credit of having first studied the European foul brood and America for having first studied American foul brond.

In a study of the so-called " pickle brood " we are mable to surergest from a bacteriological standpoint any cause for the disease. I -tudy has been made of the bacteria found upon the healthy adult bee and those found in the intestime and also the bacteria found upon and within the adult bees suffering with palsy or paralysis. but so far no sngogestion can be made from a bacteriological standpoint as to the ("aluse of this disorder of the adult bee.

To conclude. I shall read. with your permi-sion, the summary of the work reported in the bulletin referred to above.

The results of the stuly of the baterial foumel 11 rmally in the apiary may be bricefly :mmarized as f: llow:

(1) The temperatule of the hive alphoximates that of waru-blnoded animils.

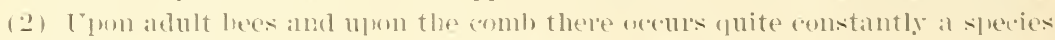

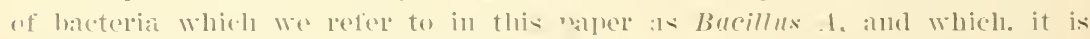

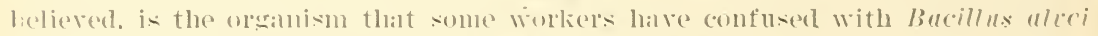
which is mirersilly present in Enoperan foul brond.

(:3) There cerours very a nstantly in the pollen and intestine of adult bees a

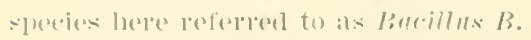

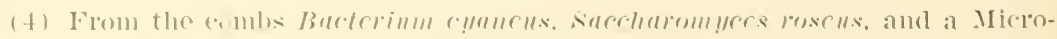

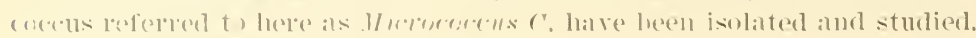

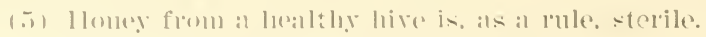

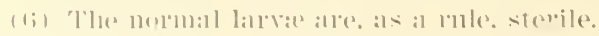

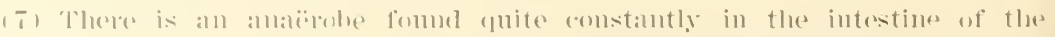

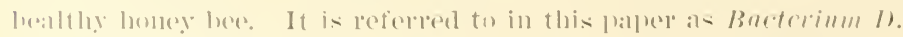

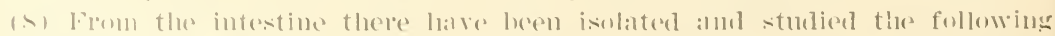

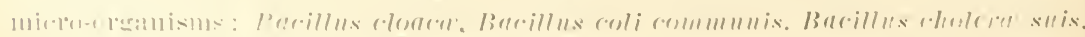




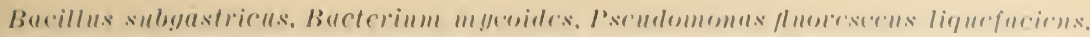

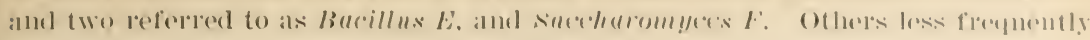
present have been isolaterl, lut not stmelierl.

(!) In two samples of brood with muknown disease there was fomml a sine ies of geast plant here referred to as sureharum!nese $G$.

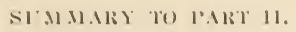

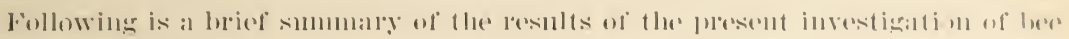
diserases:

(1) There ale a mumber of diseased comditions which afferet the aptiary.

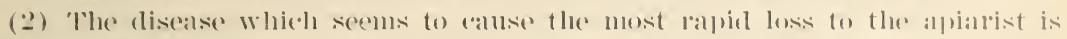

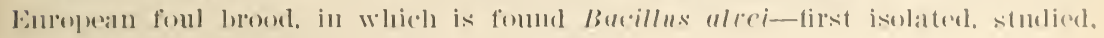
:mel named by cheshire and ('heyne in 185.).

(3) The distribution of Bacillus alrei in the inferted hive is as follows:

(a) The greatest number of infecting germs are fomm in the bodies of alead iarvir.

(b) The pollen stored in the cells of the foni-hrood combs contains many of these infecting orginisms.

(r) The honey stored in brood combs inferted with this disease lats been found to contain a few batilli of this species.

(d) The surface of combs, frames, and hives may be contaminated.

(c) The wings. head, legs, thorax, aldomen, and intestinal contents of adult bees were found to be contaminated with Bacillus alroi.

(f) Bucillus ulrei may alpear in cultures midle from the ovary of queeni from European foul-brood colonies, but the presence of this speries surgests contamination from the body of the queen while the cultures are being marte incl lias no special significance.

(4) The disease which seems to be most widlespread in the Cunited states wo have called American foul brood, and the organism which has heen fomm constantly present in the disease we have alled Bucillus Iarm. 'This disorelere was thought hy many in this combly and other countries as well to be the foul brood desiribed by Cheshire and ('heyne, hut such is not the case.

(.) From the nature of American foul bood it is thought that the organism has a similar distribution to that of Bacillus alcei.

(i) It appeals that European foul hrood was erroneously called "New Fork leee discass" or "black hoorl" by Dr. William li. IJoward in 19000.

(7) There is a diseased condition affecting the brood of bees whith is being (alled by the bee keepers " pickle hrood." No conchusion can he drawn from the investigation so far as to the cause of the disease.

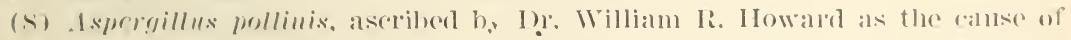
pirkle brood. has not been fomnd in this investigation and is not helieverd by the antlor to have any etiological relation to the so-called "plickle lunod."

(9) I'alsy or paralysis is a diseased condition of the adult bees. No cont(alusion eam ret be drawn as to its amse.

(11) Formaldehyde gals as ordinarily used in the appiaries is insuflicient to insure complete disinfection.

conemestons.

In a paragraph the author wishes, if possible, to present the status of the loee

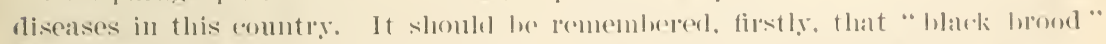

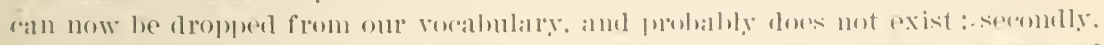
that the term " foul hrool " was heing alplied to two distinct discases. One of these diseases we now refer to as Emropean foml brood, beramise it first received

$305+7-N i), 70-07 x-2$ 
a scientific study from a European investigator. We refer to the other disease as American foul brood, because it was first studied scientifically in Anerica. There is one more disorder in the brood of bees which las attracted considerable ittention-the so-called "pickle brood." There are, then, these three principal discases: European foul brood, Anerican foul hrood, and the so-called "pickle brood."

Doctor Primurs. We surely have all been glad to listen to Doctor White in his most interesting account of his work. It will be well at this time to ask him any questions concerning this work which may have come to mind. Before opening this subject for discussion I wish to say that after this discussion I shall take up in detail the works which Doctor White has criticized. Consequently, if you have no objection, we will hold over until later any discussion of these papers.

Mr. C. P. Dadaxt. As I understand it, there exist these two bacilli (Bacillus alvei and Bacillus larve) and also Bacillus mesentericus vulgatus. Have you samples of all three of the bacilli?

Doctor White. Yes, sir; that (pointing to slides) is Bacillus larve; that (showing cultures) is the Bacillus alvei, and the next, Bacillus mesentericus. There are a number of varieties of Bucillus mesentericus, and vulgatus is one of them.

SYMPTOMS OF BEE DISEASES.

Mr. Dadant. Will you please give us a description of the two diseases-that is, of the conditions arising when Bacillus lareer and Bacillus alvei are present in the combs?

Doctor White. I should like to ask Doctor Phillips to answer that question.

Doctor Primlips. I shall simply quote from Doctor Whites bulletin. There was issued from the Bureau of Entomology some time ago a small circular, Circular No. 79, entitled " The Brood Diseases of Bees," and in this circular was included a description of the two diseases which Doctor White has been studying. Doctor White was kind enough to quote in his bulletin from Circular No. 79. and I shall read the descriptions.

AMERICAN FOLL BROOD.

American foul brood (often called simply "foul brood") is distributed through all parts of the United states, and from the srmptoms published in European journals and texts one is led to helieve that it is also the prevalent brood disease in Europe. Although it is foumd in almest all sections of the Inited states. there are many localities entirely free from disease of any kind.

The adult hees of an infected colong are usually rather inative and do little toward aleaning out infected material. When the larval are first affected, they turn to a light chocolate color, and in the advanced stages of decaly they becone darlier. resembling roasted coffee in color. Isually the larve are attacked at albout the time of capping. and most of the cells containing infected larva are 


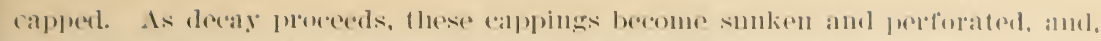

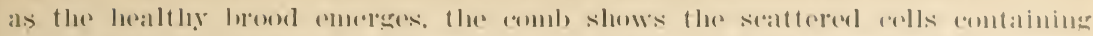

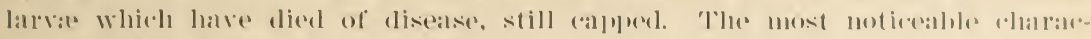

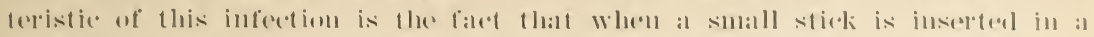

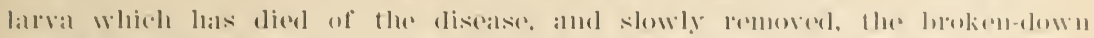

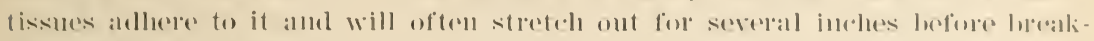

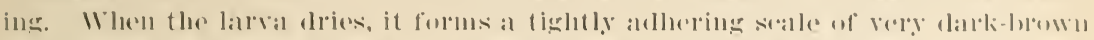

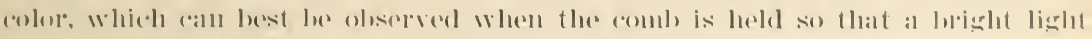

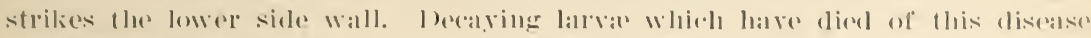

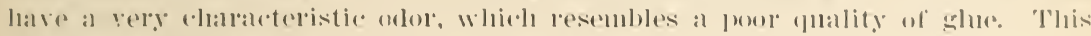

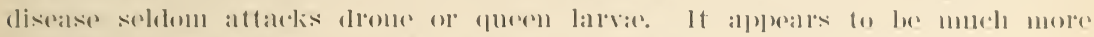
virulent in the western part of the linted states than in the last.

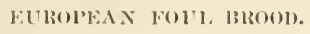

Einropean foul brood (often ealled "black brood") is not neally as widespreal in the Enited states as is Anerian foul brood. but in certain palts of the comntry it has ransed enormons losses. It is steadily on the increase and is eonstantly beins reported from new localities. It is therefore desirable that leer lierpers lee on the wateh for it.

Adult lees in inferted colonies ale not very active, but do suceped in reaning ont some of the dried seales. This disease attaldes larvae earlier than does Ameritan foul brood. and a comparatively small pereentage of the diseased

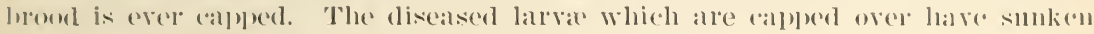
and perforated applings. The larva when first attacked show a small rellow spot on the body near the head and move measily in the cell. When deatle worms, they tum rellow, then brown, and finally almost black. Decaying larvar whirh have died of this disease do not usually stretrh out in a lomg thread when a small stick is inserted and slowly removed. Occasionally there is a rery slight "ropiness," but this is never rery marked. The thoroughly dried larvat form irregular soales which are not strongly adherent to the lower side wall of the coll. There is very little odor from dearing larva which have died from this disease, and when an odor is noticeable it is not the "glue-pot "ocor of the Imerican foul brood. but more nearly resembles that of somred dead brood. This disease attacks drone and queen larve very soon after the colong is inferterl. It is as a rule much more infectious than American foul brood and spreals more rapidly. On the other hand. it sometimes happens that the disease will disappear of its own areord, a thing which the anthor nover linew to ocene in armulne ease of Amerian foul broorl. European foul brood is most destruntive during the siring ald early summer, often almost disaplearing in late simmer and autumn.

(FEORATPIICAL, I)ISTRIBUTION.

Ml: Fraxe (Wisconsin). When I was with Doctor Phillips and Inspector Intchinson in Michigan studying the difference between American and Enropean foul hrood. it ocromerl to me that it was posible to bring together at this time specimons of diseased brood from different localities. In my own rity (Platterille. Mis.) I fomel samples of diseased eomb and had resolved them for this mesting. hut

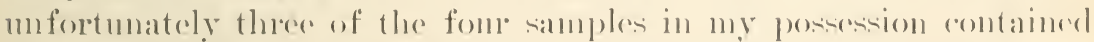
moth larvar, and it was imposible to tell anything about the disease. The only one that I -till have is now in my grip.

Mr. I).nnxt. There were those simples from? 
Mr. Fisice. Fom Michigran.

I) octor l'unlus. ()ur first acemate knowledge of Enropean foul hroed in the Inited States was the epidemic in New York State, and most bee keepers still look on the disease as -till being confined to that state. IIowerer, European foul hrood is now found in Sew Iork, Verment, Masialnusetts, Comnecticut, New Jersey. Pemmsylrania.

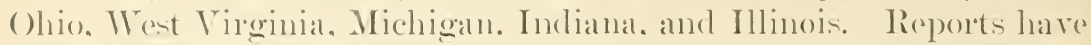
been received at the Pincan of Entomologr from all those states. The di-ealice is rapidly going west.

(OMPARISON ()F UISEASES.

Mr. Mrlana Itomare (Texas). Which of the two diseases is consiclered worse, the Anerican or the European foul brood?

Dortor Prumburs. That is a point which was simply suggested in the dereriptions just read. European foul brood spreads more rapidly than the other, but at the same time it will at times absolutely disappear of its own accord. which is something that the American foul brood seems not to do. We have these two factors over asainst each other: and I should as soon try to eradicate one disease as the other. Is far as loss is concerned there seeme to be rerre little differ('nce.

Mr. .J. Q. Amron. (Illinois). How many specimens have heen sent to the Bureau of Entomologr from Illinois?

Doctor Phillaps. Two. I believe.

Mre. surtir. I was in correspondence with some of the persons having this disease among their bees, and I adrised them to send samples to yoll.

\section{INFECTION IN HONEY.}

irr. R. A. Holekayp (Misomi). Hare the bacteria of hoth disaares been found in honer from infected hives?

Doctor Iritr. We believe that the infecting agent may be present in honey in each case. since the experience of the bee keeper has been that the infection of a healthy colony has followed the feecling of honey from hives affected by either disease.

\section{INFECTION OF L.IRV.T.}

Mr. A. IT. Anderenox (Utah). How does the larva become infected?

I)octor P'hulars. The manner ly which this is brought about is not all entirely certain, but the facts would tend to show that it is through foreling on inferted material.

I)octol Trute. It would appear that internally the contamination

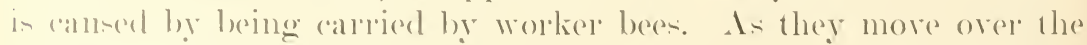

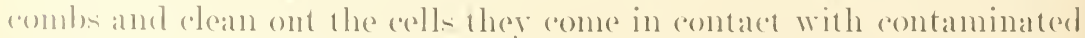

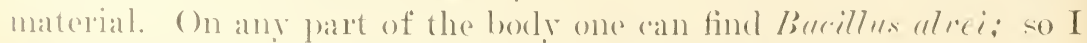
shall leare it to you, as you ale mole convel'sant with bees. 


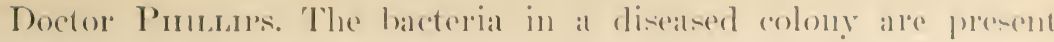

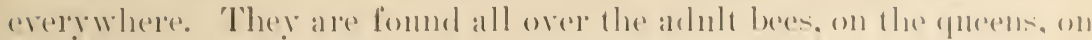

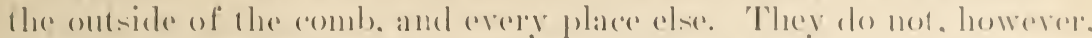

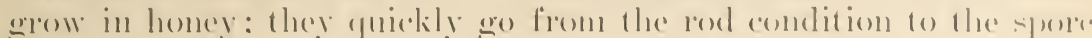
condition and remain in the latter condition indeffuitely when in honey. Aceording to the statement just made, it would seem that as bee from an inferted hive wonld always arry discase. The fact is. howerere that if the bees have been away from this infertion for some time they will not transmit the disease. Give them at new deam hive with no food. so that all the honey is nsed up from the inside of the body. The infection from the ont side dees not seem to spread the discase if no brood is reared for a fow days.

Mr. Sintru. I believe that the reason why the bee boes the infection is becalue a certain time clapses before the comb is drawn out and roung larvar are present which are large enough to become infected. But i know this fact: If you shake bees from a diseased (olony onto combs that contain healthy larva, you might as well leave the larrat. for disease at once appears. I have tried that.

\section{AC"TERIA IN QUEENS.}

Mr. D.m.xT. In either ase have the bodies of queens been inspected?

Doctor Wrinte. The bodies of queens have been inspected, and while the internal organs contained these organisms, the ovaries seldom do, and where Barillus alvee is found in the ovary, or in our cultures mate from the ovary, they occur very seldom, and the probability is that they get there through contamination in making the cultures rather than from being found in the ovary itself. The ovaries are very small and one must work with instruments that are sufficiently larege to handle. It is almost impossible to take coltures from the ovary and not get contamination from the outside.

\section{" BLACK BR(O)1),}

Mr. II. II. Root (O)hio). I thomght I understood Doctor Wrhite to saly that the disase called black brood has not been fonmed in Now York.

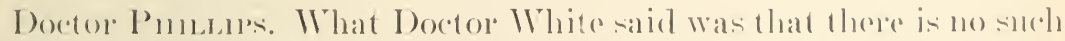
thing as black breod. The name black hrood was a blumeler.

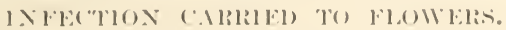

Mr. Smotu. Then if. as you saly. the contamination is always flesent on the arbult bees from diseatsed colonies. why is it not pressible to arry it to the hlosioms and leave it on the polleng so that the next bee visiting the same flower womld arrergerms to its hive?

Doctor Prmans. It is, of course posible, but highly improbable. 
VITALITY OF MPORES.

Mr. Fraxce. As to the chration of this bacilles in the spore form. how long can it remain in honey and still have vitality to grow moler proper conclitions?

Doctor Pruntris. I have never determined any limit. It is known that rery old honey from an infected hive will transmit discase to a rolony.

Mr. Fruxck. In my state (Misconsin) we had an experience bearing on this point where combs contained American foul brood. The bees had died. learing the combs containing dead dried-np larva. and the owner, anxious to start in bees again, put the hives away in the granary, ant four years afterwards hived bees on them and Imerican fonl brood started anew.

Mr. I). H. Coggshatl ( $\mathrm{N}$. Y.). When honey was shipped from Cuba several years ago and scattered all orer the United States. if it was left where bees from this country could get to it, the disease was certainly scattered broadcast.

\title{
PUBLICATIONS ON BEE DISEASES.
}

Doctor Prillips. I desire at this time to annonnce the publication of three pamphlets on bee diseases issued by the Bureau of Entomology. Circular No. 79, "The Brood Diseases of Bees," was issued three or four weeks ago. I have just this morning received copies of a paper by Doctor White. Technical Series, No. 1t. entitled. " The Bacteria of the Apiary, with special Reference to Bee Diseases." This was issued on November 6, and was received here this morning. I have also a pamphlet here from the Burean of Entomology containing all the laws in force relative to bee-disease inspection. This is a reprint from Bulletin No. 61. " The Laws in Force Igainst Injurious Insects and Foul Brood in the United states." A recent oreler of the secretary of Agriculture has put a stop to the free distribution of bulletins, but they can be purchased from the superintendent of I)oemments. Government Printing (Ofice. Washington, I). (". The price of 'Technical series. No. 14, is 10 cents.

The following paper was then read hy Doctor Phillips:

\section{THE PRESENT STATUS OF THE INVESTIGATION OF BEE DISEASES.}

\author{
lig. L. F. I'Huldur. I'h l).. \\ of the I. S. leputment of terriculture.
}

I wish to take up two or three phases of this work about which I)octor White has been speaking. and to add some additional points. In regard to the history of the inventigation of bee diseanes prior to 1ssi. I an do no better than to quote the historical resumé eontained 
in a paper by Prof. F'. C. Harrison, entitled "Foul Brood of Bees," published as Bulletin 11.2 of the Ontario Agricultural College:

In all frobaloility the first definite reference to foul hrood is ly . Aristotle (Historia Animalimm. Book IX. (h. 2- T), who mentions an inertuess whirls scimes the bees and causes a bad smell in the hive. Ile also suggests that beres are liable to beeome diseased when the flowers on which they work ar. attacked by blight. Bee dysentery ats well as foul brood rauses a bal odor; but in the former discase the spotting and consequent smell are nsually outside the hive.

Columellat (De Re Rustical. Book IX, ch. 13) mentions a hee pestilence and an ammal distemper which seizes the bees in spring. I'ling (Natural llistory. Book XI, (h, 19, A. I), 7!) writes of a disease of bres, but as he uses the same term as Aristotlo he has probably eopied it from the latter anthor.

Schirach (Histoire des Abeilles, (h. III, p. 5(i, hal llaye, 1771), in 1769, w:1s the first writer to mame the discalse "foul brool." Ile salys:

It is dangerous and a most destructive disorder to the bees, a genuine plague when the complaint has reached al certain stage. The caluse can he attributed to two sources: (1) The putrid (or talinted) food with which the bees ferd the larvar for lack of having better. (2) By the mistake of the queen bee in misplacing the larvie in their cells. head upside down. In this position the young bee. unable to get out of its prison, dies and rots away.

Further, schirach clearly distinguishes between foul brood and ehilled brood, and mentions the fact that putrefaction follows the death of the brood from frost, lut in this case " it is only an accident and not a disease."

The remedy schirach recommended was to remove all diseased combs from the inferted hives and to keep the bees fasting for two days, after which they are furnished with other cakes of wax and a suitable remedy given, "as a little hot water mixed with honey, nutmeg, and saffron, or a s.rup composed of equal parts of sugar and wine seasoned with mutmeg." Thus, as cowan (Journal of the Royal Agricultural Society, Vol. VI, Part IV, 1895) remarks: "Wr hat given us nearly one hundred and thirty years ago a method of eure almost identical with what is by some claimed as new to-day."

Tessier (Lincyclopedic Methodique, Abeille, 1) 32, 1765) about the same time as shinirch salgs that when the larve die in their cells it rauses an infortion in the hive which makes the bees sick. It is then necessilry to drive away or sometimes move the bees from the hive. and to take care to fumigate the infected hive if it is going to be used again. It is necessary, in order to aroid the same incomvenience, to take out the parts of the comb that may be moulded by reason of the dampess. Duchet (culture des dheilles, p. 315, Verey, 1771). who wrote on bees in 1771, does mot mention any disease that "an le certified as foul brood, but he deseribes bee dysentery.

Della Rocea (Trate (omplet sur les dbeilles, Vol. III, p. 261. Partis, 1790), vicaire-general of sira, an island in the Levant, relates with much detail the listory of an epidente of fonl hrood, which alused great destrurtion in the

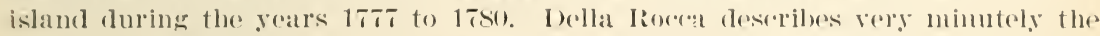
symptoms, destruction, and mistakes that were made in attempting to combat the disease. He says:

The disealse manifests its presence by defects in the combs filled with brood. and which only contain a putrid mass; instead of the bers pupar there is only rottemess in the colls, which, howevel, heing rapperl. always meserve a healthy appearance. If these cells are broken open, a hlackish liquid flows out. which spreads the infeetion through the hive. This disease only manifests itself in colls which contain a neally matne larva or a capped one. The bers themselves remain in gond health, and work with the same activity, but their mumbers decrease daily. This disease. howrere, was not so general in a hive 
but that il small portion escaped. Some new hees emerered lut in too small

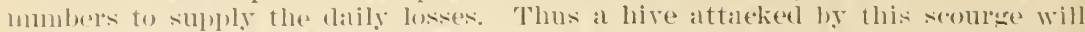

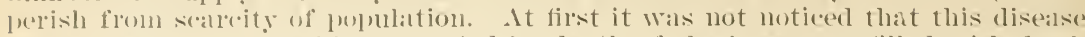

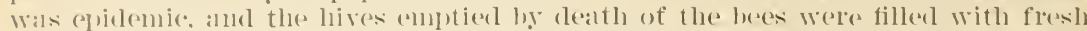

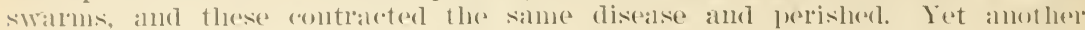
mistake was nolde. The remalus of the hives that were lost were talien into the strests of the town to expose them to the sum in orelel to extratet all the wax.

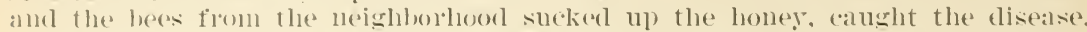
ancl communicated it to other lives. and all, without exception, perisher in al short time. The epidemic having reathed the island spleat ererywere. and the moltality anone the bees was genelal, either from eating inforterl homey. or from stopling up the infected combs, or from the bees nomrishing their brom (1) infecterl honey.

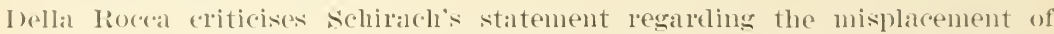
the lanvar hy the queen as a caluse of the disease, hecaluse "everghody knows that the queen has nothing else to do but deposit egas. These are then (ared for and nourished by the bees; and when the larva is nearly ready to (.hanges inte the pupa, the bees close the cell, and every position which is griven the latral

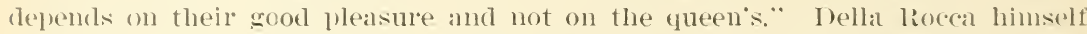
thinks that "some pestilential blight had without doubt corrupted the guality of the honey and the dust from the anthers," and recommencls " lourning everything without pity, as there is no other resource when the disease is well established, as the pest is without doubt the most terrible in the natural history uf bees."

Neither Wildman ('Treatise on the Management of Bees, London, 1796). Kers (Ancient beemasters Farewell. London, 1790, Woolvidge), Needham (lipussels Memoirs, Vol. II, 17so. Rhein). Reaumur (Memoirs pour servir a l'llistoiro Naturelle des Insectes. T. T., 1). 17:34), and othel authors about the same time (latter end of the eighteenth century) mention this disease.

Beran (The Ioney Bee, London, 1827) names the disease " pestilence," and also quotes Schirach's name, "foul brood," and says regarding it that the "pestilence has been attributed to the residence of dead larvie in the cells. from a careless deposition of ora by the queen. * * * It has also been attributed to cold and bad mursing; that is, feeding with unwholesome food."

Nothing further of note appears in bee literature till the rear 1sto, when Doctor Le'uckhart (Bienen Zeitung, Eichstalt, 1Sto, 1). 20.3) writes that he was formerly of the opinion that foul brood was causerl ly the same fungus (Panhixtophyton oratmm) which is noticed in a disease of the sillworm. but now, after observation and experiment, is quite rertain that the discase is ansed ly neitler regetable nor animal parasite. He also notes that the trom "foul brour" is applied to a number of diseases affecting loes.

Molitor Muhlfeld (Bienen Zeitung. Eichstadt, 1s(s, ). 9.্) recognizes two forms, one contagious and the other not contagions. and thinks that the only"

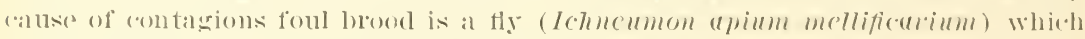
lays its exess on the young landiat of the bee.

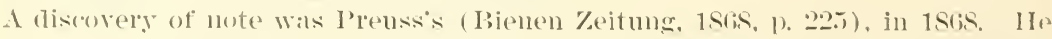
rontladicts Mululfeld's statement about the fly, and states that foul-brood reells

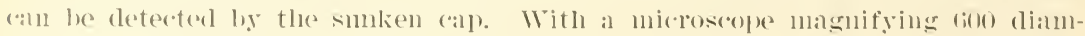

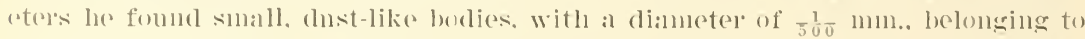

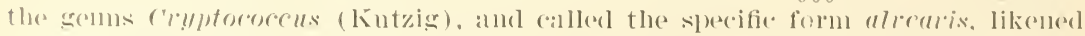
it to the fermentation fungus (

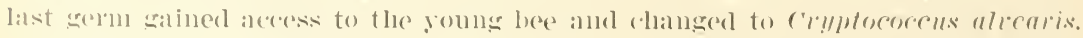

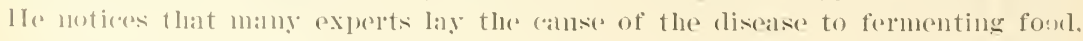
hut the lanvar ale easily antaminated by the fermentation fungus, which is

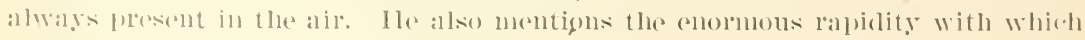




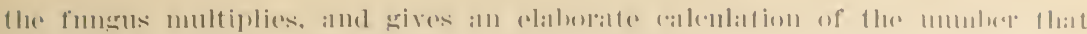

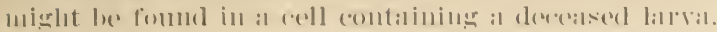

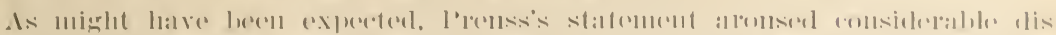

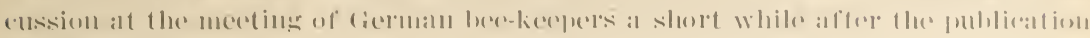
uf his palpere.

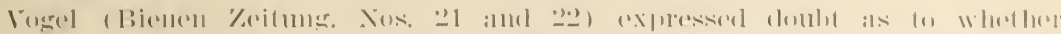

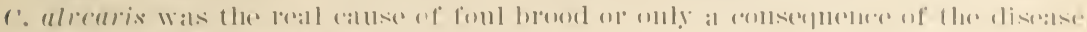

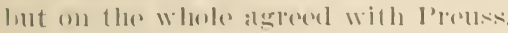

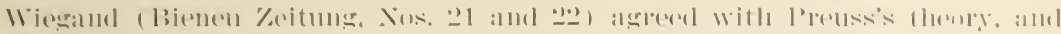

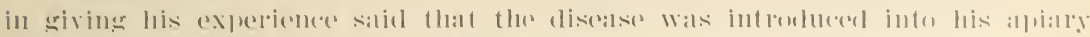

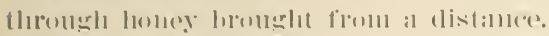

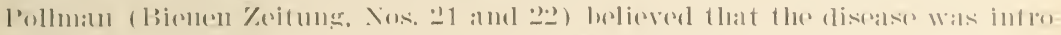

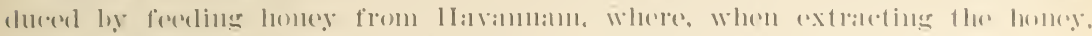

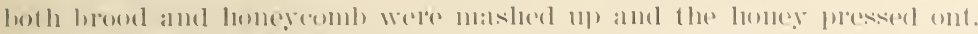

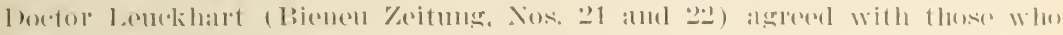

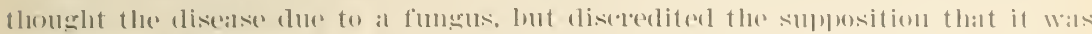

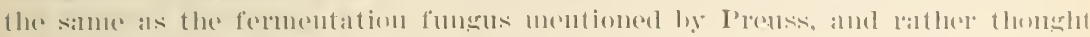
it was rebited to the silkworme fungus and that most of the hood diserases

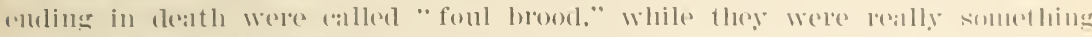

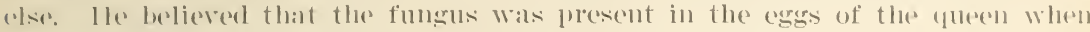
lil icl.

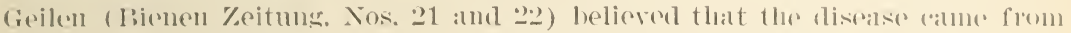
the putrefying remains of animal boties upon which the bes alighterl.

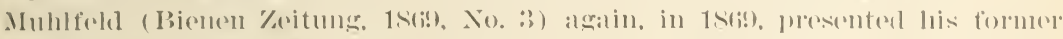
views and also those of I'reuss and galve dirertions for manitaning the health

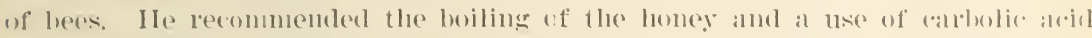
in the strength of $1: 100$, or permanganate of potatsh 1 : :300, als disinfortants.

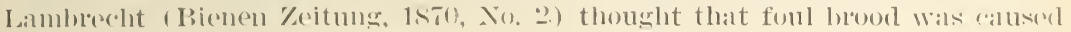
ly fermentation of the bee breal.

Ilallier (Bienen \%eitume. 1570. No. 丷) considered it no sperific diseatse, but

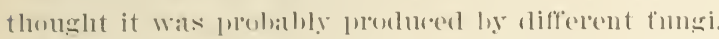

Cormallial (Bienen \%eitung. 1sio, No. i) proved contrary to the above and

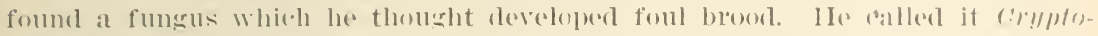

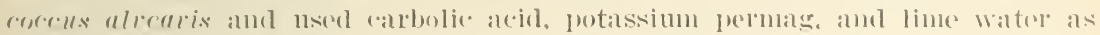
disinferetints:

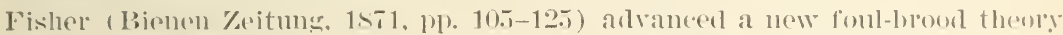
in 1sit, whirh somewhat follows the view of Liebse regatheng the silliwom

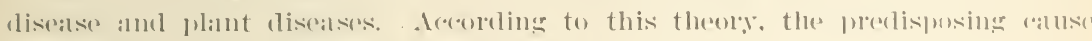

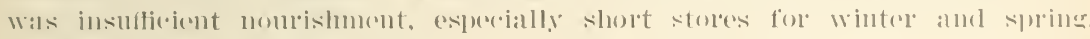

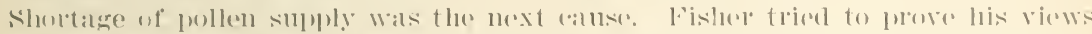

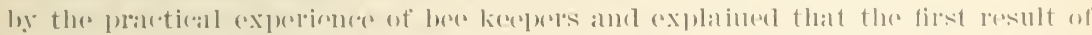

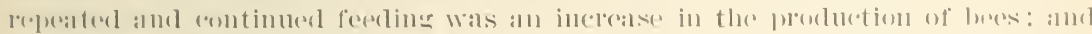

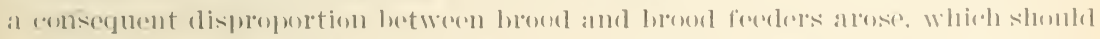

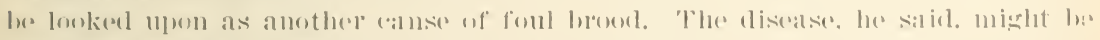

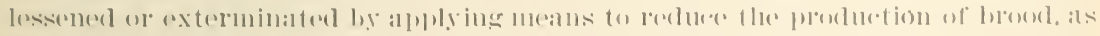

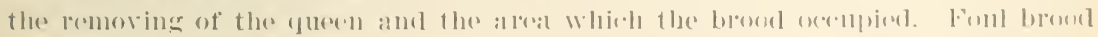

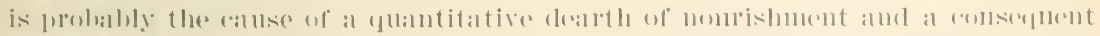

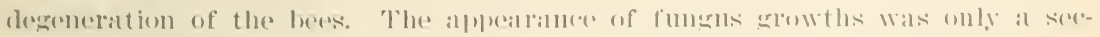
ondiary matter.

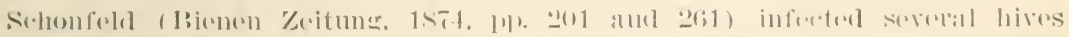

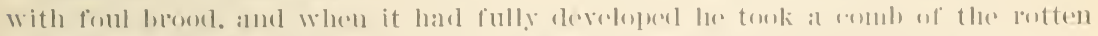

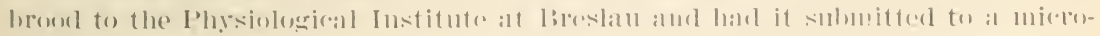

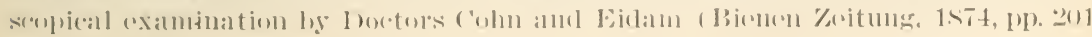


and 261). This examination showed that in erery dead larva and in each foul browd and, whether the contents were yet white and fluid or brown, tenacious, and rops, there were to be found long wal bodies, which Irenss called "nicrororei." ('lose to and ammeng them, cohn was the first to find. with the most powerful of the fire nicresenges that were used, a countless number of slender pale rocks, joined togethere, and whieh he at once identified as barteria of the semus burillus. The length of a single rod was about f micromillimeters, but many of then were two and three jointed, so that these foul brood bacteria microsenpinally resembled the anthrax bacteria, though of course they were different physologieally and in the mamner in which they acted as ferments.

It is not surprising when we remember the state of bacteriologieal knowledge in 1570, that I'reuss should have mistaken microcoeci for the spores of a bacillus.

In 185.5 the first investigation which merited close attention was publisher in the Journal of the Royal Microscopical society, entitled * The Pathogenic History and History under Cultivation of a New Bacillus (B. alcei). the Cause of a Disease of the Hive Bee Hitherto Known as Foul Brood," by Frank R. Cheshire. F. R. M. S.. F. I. S.. and IT. Matson Cheyne, M. B., F. R. C. S. One point is here to be especially noticed, there were two authors of this paper. 'The paper was divided into Part I, Pathogenic History, by Mr. Cheshire, and Part II, History Under Cultivation, by Mr. Cheyne, and with the latter part Mr. Cheshire had nothing whatever to do. Bee keepers are generally giving Mr. Cheshire the credit for this work, but it is clear that Mr. Cherne, the man who did the bacteriological work, should be the one to get the credit. The description of the disease. contained in Part I, is as follows:

The nuture of foul brood as a germ disease.-If a comb he remored from near the center of a healthy hive during the summer months its cells will nolmally be filled with eggs. larve, and pupie in every stage of development. 'The egrs as left by the oripositor of the queen or mother adhere commonly by the end to the base of the cells they oceuly, and favored by the high temperafure constantly maintaned within the hive. the creminal vesicle at about three days matures into a larva ready for hatching. These eggs I have shown as liabe to the disease eren before they leave the body of the nother. hut most careful midorosopic examination is needful to mike this aplatrent and of which I shall speak presently more particularly). On the contrary, the larve which are constantly fod hy the workers. so change in appealince soon after infection that a prateticed eye at once detects the presence of the disease. Whilst lealthy their boxlies are of a beatutiful pearly whiteness, lying. at first floating. in the abundant pahulum the nurses are ever realy to supply. As they grow they conrl themselves at the bottem of the cells until they become too strait for their ocrupants. which now adrance to the head to be in readiness for the rocoen spiming, which follows upon the close of the eating stage. When the disease strikes the larve they move uneasily in their cells. and of ten then pressent the dorsall surface to its mouth. * * * so that mere posture is no insuffirent evidence of an unhealthy condition. The color changes to yellow, passine

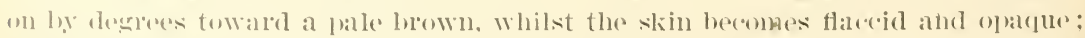
death som arens, when the hody, now shrunken ly exaporation, lies on the lower side of the aell. increatsing in depth of tone, until in a few days nothing 


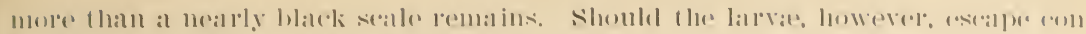

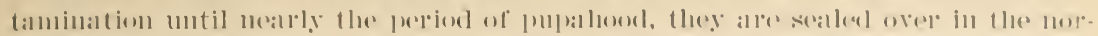

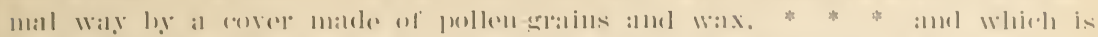

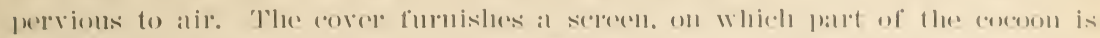

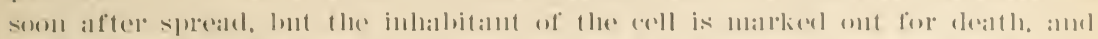
befoles very lomer the (alp) jmIIt

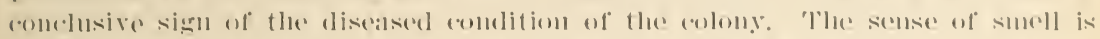
also

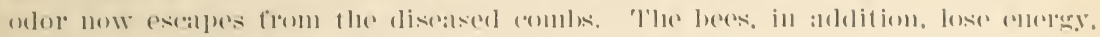

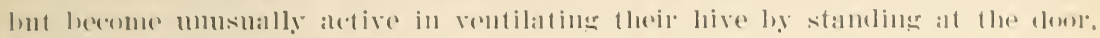
leads toward home, and tlapping their wings persistently so that a strome ont-

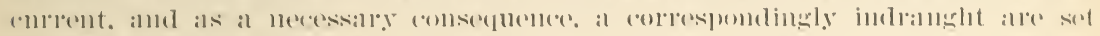

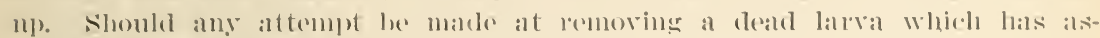

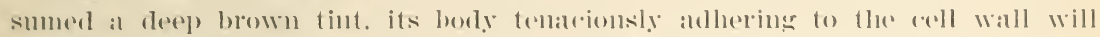

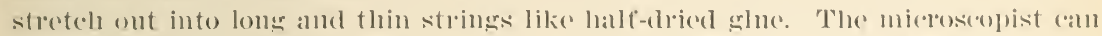

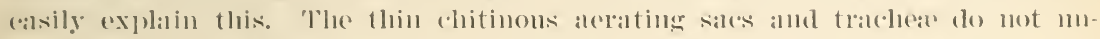

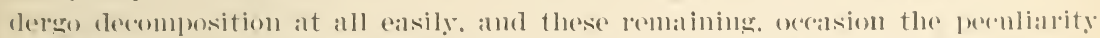

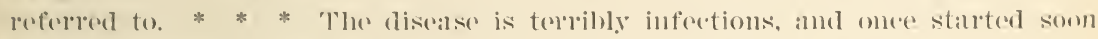

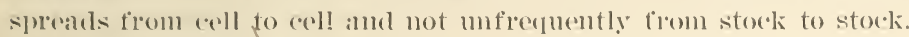

Mr. Cheshire was doubtless quite familiar with the disease of the hrood and this description of the symptoms, we may assume. Was not made from any one case, but from his entire experience. At.that time two diseases of the brood were not recognized. We are justified in concluding that both diseases existed in England at that time. as they do now, and doubtless Mr. Cheshire had seen both withont realizing that he was dealing with two distinct maladies. In this description he speaks of the disease as attacking brood at rarions times, for he says: ". Should the larva, however, escape contamination until nearly the period of pupahood," ete. Ilis dencription before that sentence applies as well to what we now (all European foul brood as to American foml brood, while the latter description, expecially where lae speaks of the odor and ropiness, is modouldedly drawn from experience with what we now all American foul bood. There i.s, at any rate. erenud for the supposition that Mr. Cheshire was dealing with two discases.

In the case of Mr. Cherne. however. the case was entirely different. He was probably not familial with the brood clisease frem practical experience. He also probably dicl all his work from one specimen. for

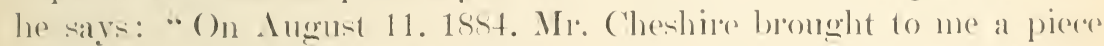
of comb containing larrer affected with foul bood, with which I performed the following experiments." In deveribing this specimen he says: "These laprar were dearle of a rellowish colole and almost liquide." This deseription certainly applies as well to European foul

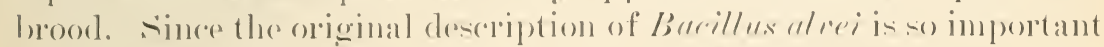
in this work, it may be well to fuote entire Mre. ("hernes part of this paper. This is practically mavailable to bee kerperts since it is con- 
tained in a jommal to which few bee keepers can have access. It is is follow:

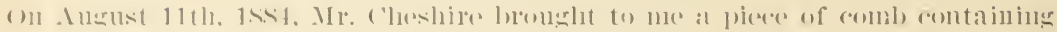

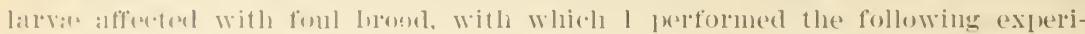
ments: sederting adls which were closed. hut which Mr. ('heshire thought eon-

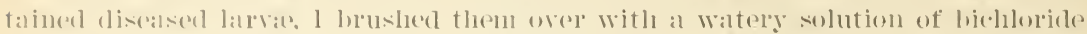

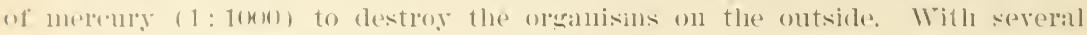

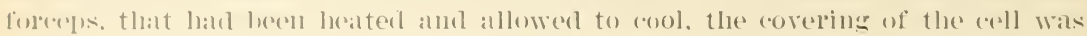

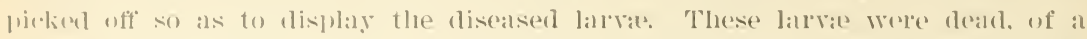
rellowish aolor. and alunost liquin. and on examination afterwards their juices were fomml to rontatin mumerous noving batcilli. By means of a leated platinum wire, tubes of meat infusion rendereal solis ly gelatin (10 lee rent), or lỵ Jillanese isinglass, were inoculaterl from sereral of these larve and kept at al

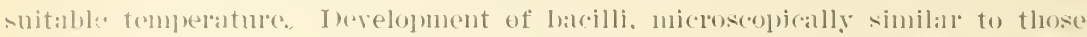

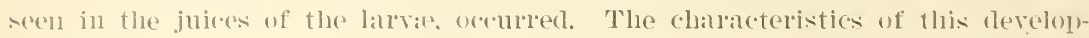
ment will he presently described. Furtler, in the tubes, kept at the lody temperature. there was not only a development of bacilli but also of spores.

These bacilli, as seen in the larval juices, measure about $\frac{1}{000}$ inch in length and 205 , inch in hreadth. They are rounded or slightly tapering at their ends and uften liave a clear space near one end. In the juices of the larve during life they apparently do not produce spores, althoush after deatli spores aboumb.

In the cultivation in the peptonized meat infusion, rendered solis by agalr-agan. the harilli vary consiterably in size, their arerage length being $=1 . \overline{0}$ inch, some being as small as $\frac{1}{10}$ inch and others as large as $\frac{1}{500}$ inch. When they have attained the latter size, division of the rod seems to begin. They are always somewhat printed at their ends. Their average breadth is $\frac{1}{30000}$ inch, varying from $\frac{1}{35000}$ to 11

The spores are largish oval bodies, averaging in length $\frac{1}{1} \frac{1}{0} 0 \overline{0}$ inch (varying from

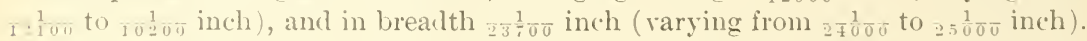

In the agalr-agar material the spores are generally arranged side by side in long lows, and in old cultivations only a few bacilli ean be seen, some forming spores. some without any inditation of spores. That these small hareilli can

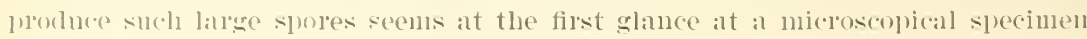
almost inconcrivalule. lunt I laive been able to trace on the one hand the derelopment of the spores in the rods, and on the other the slurouting of the spores into andult balcilli. This an be done in the following very simple mamer:

Talke a mumber of eliss slides, eatch liating a moderate-sized cell hollowed

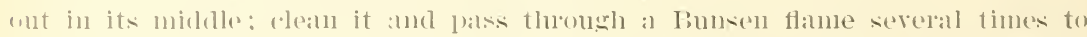

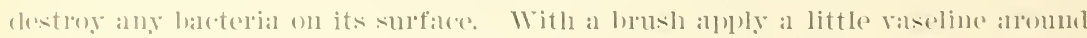

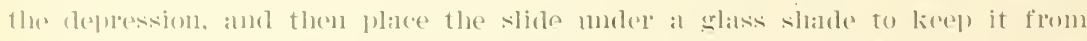

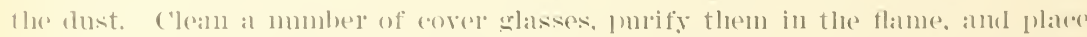

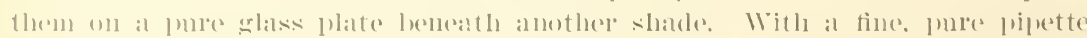

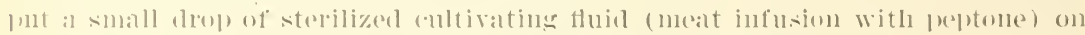

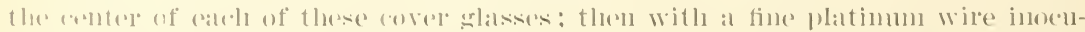

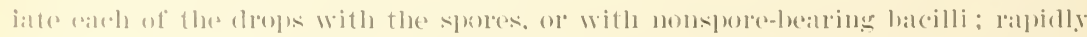

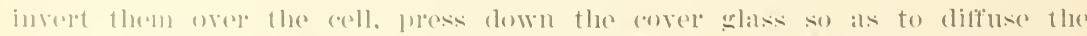

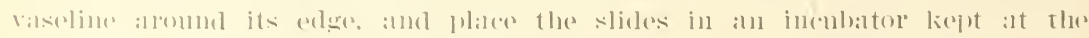
tomperatme of the body. These slides are removed at afferent intervals of

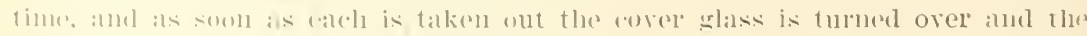

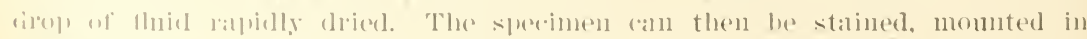

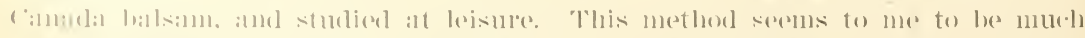

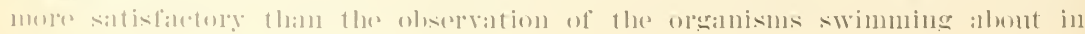




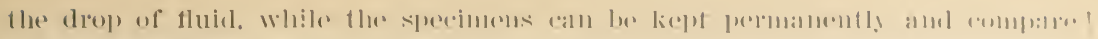
with (116: allotllel.

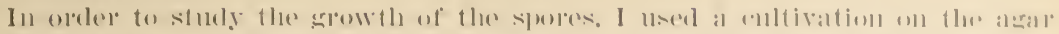

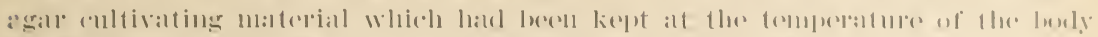

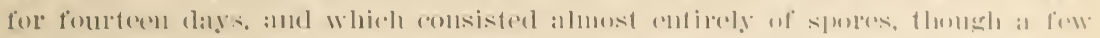

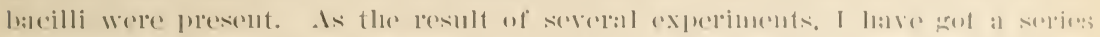

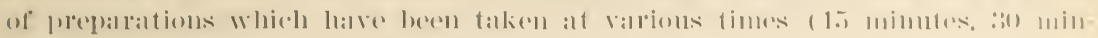

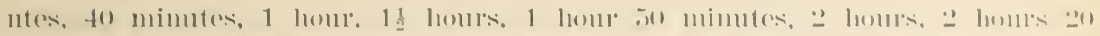

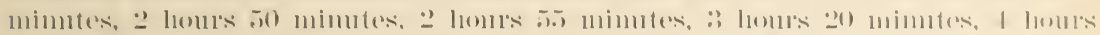

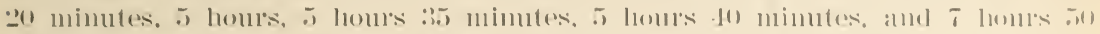

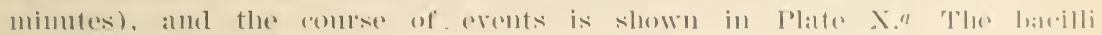

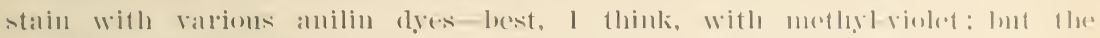

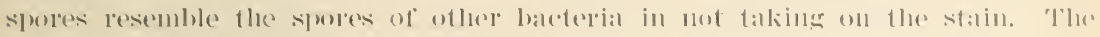

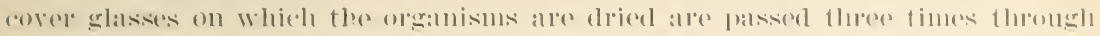

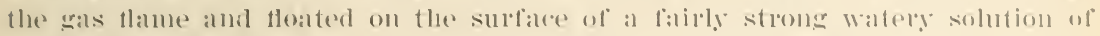

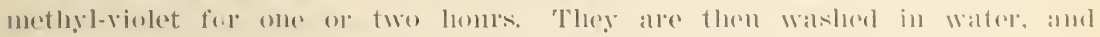

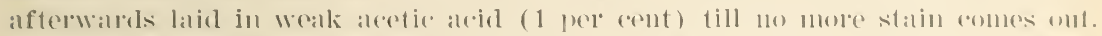

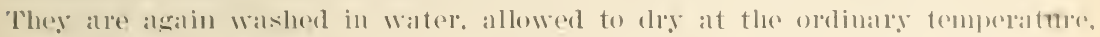

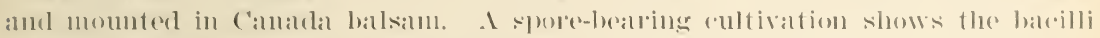
stained violet and the spores unstained, with the exeeption of theil ontline. which is of a faint violet colole. In most eases no tratee of the lose in which

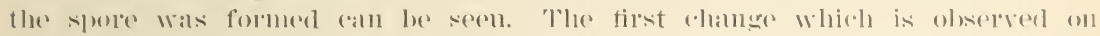
enltivation is that in many rases the outline of the lool in whiels the spole was formed heromes fantly visible. This eall be seen in 15 minutes, and is, 1 think, simply due to swelling by the fluid, as it is also evident to some extont in the ease of spores soaked in water for the same lengtle of time. In form half an hour to an hour it is evident that the bateilli which were present in the original natrial a lo berimning to nultiply, and a considelable number of lock are $110 \mathrm{w}$ seen containing spores. It is evident that tlese spores ale newly formerl, as extremely fow bacilli eontaining spores wele seen in the original material, wheleas in the propalations taken from a half houl to all hom a eonsiderable number are present. That some of the rods. insteat of growing

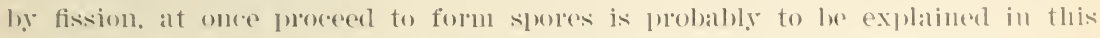
way. When the eultivation was removed from the incubator. some balcilli wele growing ly fissin. some were folming spoles. and some had passed into al state learly to form spoles. The first go on growing by fission, the last complete theil spore-formation. Which was arresterl lọ remosal from the wallu temprial-

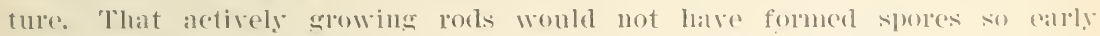

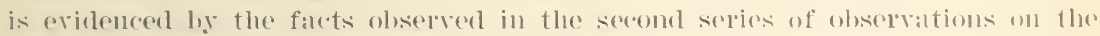
formation of spoles. The next thing that is olserverl is that several of the spoles take on the stain, and ale as inteusely violet as tle alult lobeilli. The

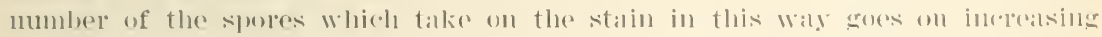
as time passes. till in about four homs almost all the slubes stalin violot. lu

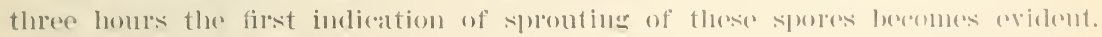

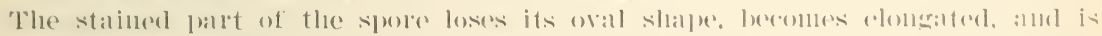

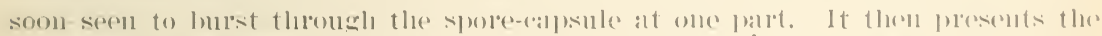

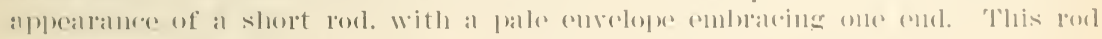

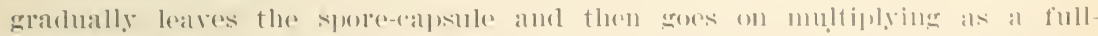

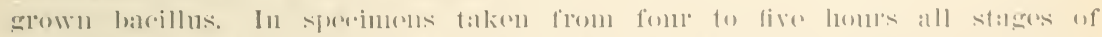

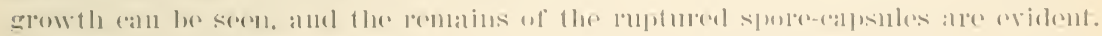

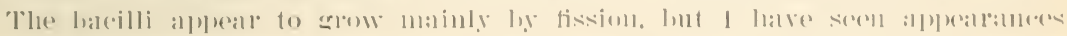




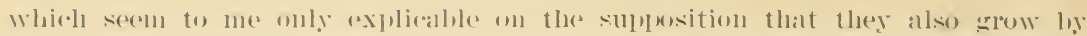

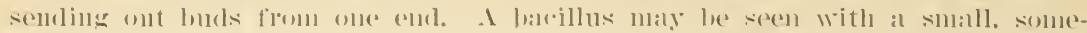

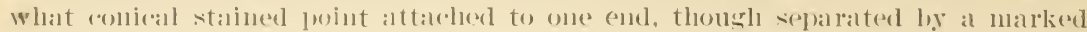

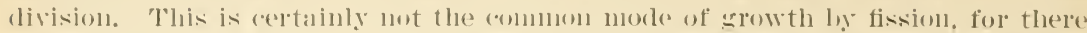
the rod serems to divide into two jeretty epual halses. while here we halve hut a

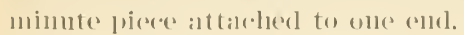

The mode of formation ot slumes maly be trateed in at similar malner to that

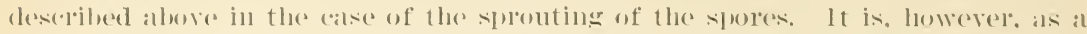

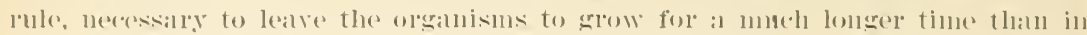

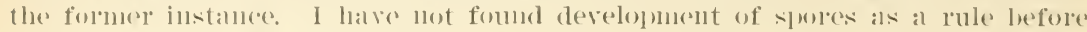
twenty-three houls, hut this depends very much. alplatrently. on the antount of Huid that wals present and the mumber of bieilli introduced at the time at inorenlation. The first thing noticeable is that the rod logeris to swell and beromes spindle sliapert. 'The swelling. Which semerally affects the midelle of the rod. may in some ases be most marked toward one end. inceases in size. and the center of the swelling grablually ceases to talie on tlee stalis. 'The ('ap)sule of the spore is apparently also formed within the rod. and is not merely the outer part of the rod. In three or four hours the rod is seen to have almost or completely disappeared, leaving the spore lying free or within the faint outline of the original hacillus. It seems to me that the view that spore formation ocrurs when the food is aretting exhausted is correct, for the time at which this anjenrance is found depends greatly on the drop placed on the cover glases, and I latre found in one experiment that in one specimen, after twenty-three hours. most of the rods were forming spores, while in another specinen where the droll was much laleer there was no trace of spore formation after twenty-eisht homis. I have here described the results of my earlier and rourler attempts to study the formation of spores. I have, however. now improved the metlud in the following way. As I have just now shown, the period at which spores ale first seen seems to depend mainly on the amount of fluid used and the number of hacilli introduced. and as in the above method. both thene factors vary in each case, one can not get a regular series of preparations showing the different stages at different times. In studying the sprouting of spores tlese amount of fluid and the number of spores does not matter. for if sufficient nutriment is present and a proper temperature is maintained the spores must sprout. and probably they always take about the same length of time. The difficulty of ohtaining a series of specimens illustrating spore formation is easily olviated in the following mammer. Take a pure flask containing a small quantity of sterilized infuxion and inoculate it from a cultivation containing only balcilli. l'lace it in the inculator for two or three hours so that the bateilli may incerease somewhat in mumber and diffuse themselves thloush the ligaid. Thus the cultivating material eontalls bateilli prettr efually diffused throush it, and if after

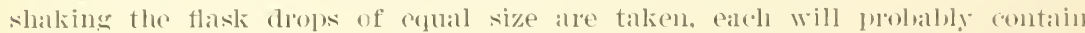
alout the silme number of bareilli. The minutest quantity of fluid ain easily be ohtained ly meatns of a syluge having a fine serew on its piston and a lange

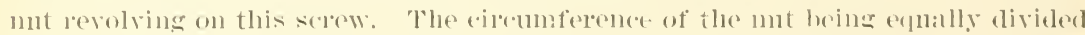

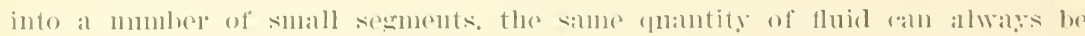

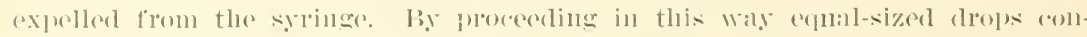

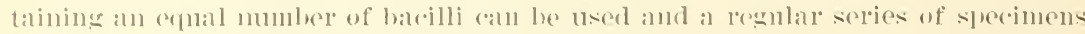

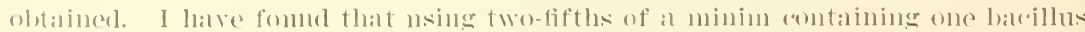

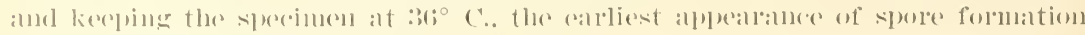

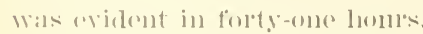

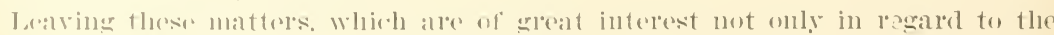
Burillus almi. but to all spore-bearing hareteria. and which I have therofore 


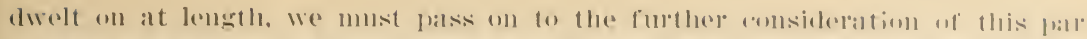
ticular organisur. The tirst point to be determined in investigating its relattoul

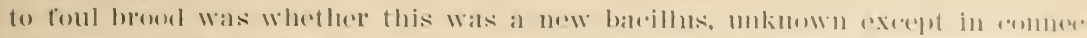

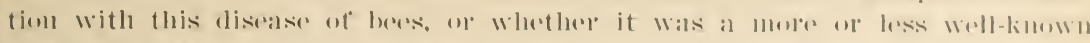

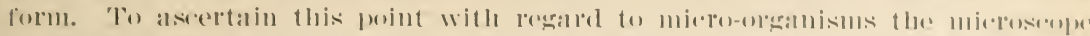

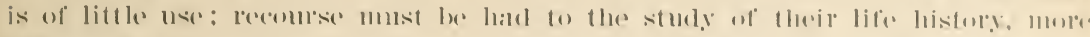

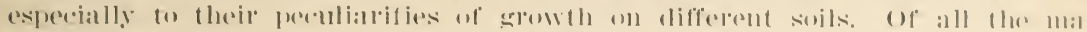

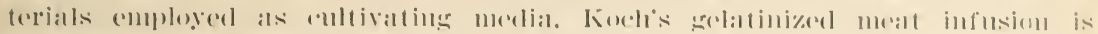
the most useful for purposes of diagmosis. This is ampused of an infusion

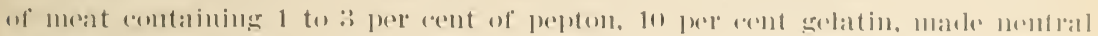
by atobonate of sodal, and thomenghly sterilized. This material wats filst in trodured with the view of having a highly mutritive solid allel at the sillue

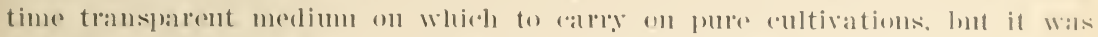
soon foumb that owing to the remalrably diverse wals in which different micro-orgatnisms grew in it, it comlel lie used as a means of diagnosis of the kind of orgatlism, a means more certatin than ally ofher which we at present possess. For purposes of diagnosis, as well as with the riew of alrying ou more cultivations, this material is used in three ways. While the material is still fluid a small portion is poured into a number of pure tubes plusered with cotton wool, sterilized, and allowed to solidify. A finc platimm wire, heated in al thame and allowed to eool. is dipped into the matlerial comtaninger the bareterium in question. and then, after the removal of the atton-wonl phus, is rapidly plunged down through the gelatin to the bottom of the tube and then withdrawn. The plug is reinserted and the tube kept at a temperature suitable for the development of most forms of barteria, hut not high enomgh to melt the gelatin. If growth takes plare at this temperatme it oxems oither (n) the surface around the point of entrance of the needle, or along the needle track. or in both places. and the appearance of the growth varies remallably. according to the different sperjes of miero-orginisms studied. The serond wily is to liquefy and pour out a little of the gelatinized material on mierosenpe slicles or on larger plates of glass which lave been strerilized by heat. These plates are placed in glass vessels containing moist blotting paper to prevent drying of the gelatin and to protect them from the dust. After the gelatin las solidified the purified platinum necolle rlatred with the bateteria is dratw rapialy over the surface of the gelatin. Bareteria ale sown along the track,

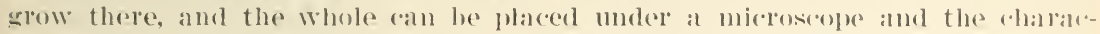
teristics of the growth studied with a low power. In the third molle a tube of the selatin mixtme is inoculated with a rery minute quintity of the bileteria. The tube is then placed in water at the body temperature to nole the gelatin. When the material is melted, it is thoroughly shaken up to diffuse the bacteria through it and. While still liguid. is poured out on sterilized glass plates kept in a moist chamber, as in the former case. Soliclifiation repry soon oecurs, and the batereria being eaught at various parts of the seclatin grow there in the form of groups or colonies. which ean be observed under the low power of the mireseope. I shatl now deseribe the rhalateteristics of the Bucil!us alrei when rultivated in these three modes.

(a) Test-fube culfications.-If an infected needle le plunged into a tube of

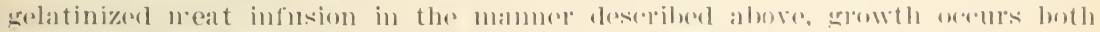

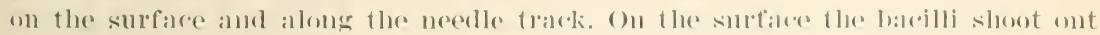

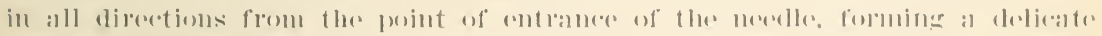
ramifying soweth on the tow of the eselatin: the ehaldeteristies of this grewth will be presently deseribed under b. . Moug the trati whitish irregulat slatped masses appear. which slowly increase in size and rmu together. In a few days 


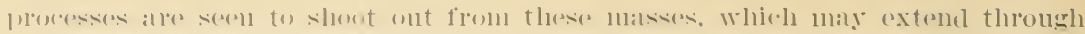
the gelatin for lons distances from the trake, being thickened at rarious parts

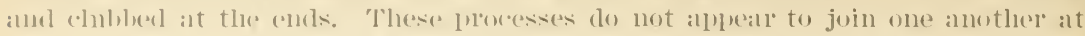
their emls. A very leatutiful and dallateteristic alpearance is got where very

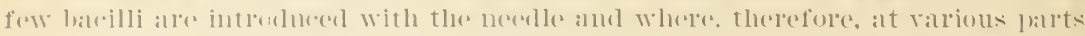

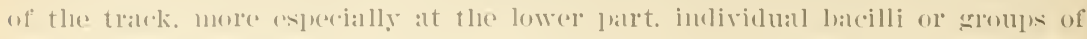

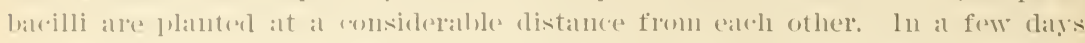

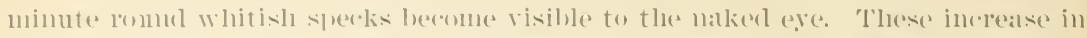

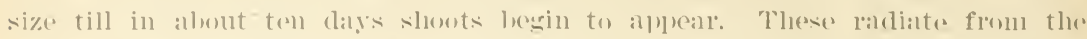
rentral malss in all direetions and heconne molular at various parts, as deserileed

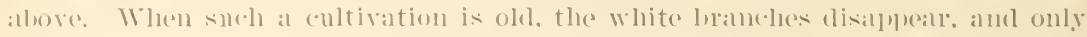
little whitish eolleetions of hareilli ale seen at various palts. On examining such a tule with the poreliet lens, howerer, numerous waterg-looking tralcts are serel ruming throush the golatin from the central mass to the whitish collections. The gelatin at the uluer part of the track generally evaporates, to sone extent giving rise to the air-huble alpearance so charateristic of the cholear hatcillus. These are the appearances seen where the material contains gelatin in the proportion of 10 per cent. Where less selatin is present. the nalied eye alpearances. while possessing the same chalacteristics. are somewhat different. The shoots are much more numerous and appear much more rapidly, giving rise to a hatziness around the middle track. which with the preket lens is seen to comsist of mmerous delicate hranches clubhed at the ends. as in the former alse. I think the amount of pepton present also makes a difference in the appealrance. though of this point I am not ret al,solutely certain. The nost characteristic. growth is, howerer. oltained when the material contains: per rent penton as well as 10 per cent gelatin, the shoots being then less numerous and much coallser. And I can easily understand that this would be the case. for the hateilli would have a large supply of nutriment in their immediate vicinity without the necessity of having. so to speals, to spread out through the schatin in search of food as may be the asse where no pepton. or only a small amount. is present. This alpearame is guite characteristic of this bacillus and is not seen in the cultivation of any other organism that I know of. The bacilli of anthrax and of mouse septiearmia also spreald out from the needle tratek. lout the apprallamer of their cultivation is quite different. In anthrax delicate threalds, not clublud. sheot out from the track, soon anistomosing with other threaks and forming a delicate network throughout the gelatin. In mouse septicamia the aprealrance is that of a delicate clouliness spreading through the gelatin. These foul-hou d lareilli. srowins in this material. render it liquid after a time. the liquefaction besimnins at the surface and only spreadins slewly downwards. but ultimat tely the whole tule becomes lirpuid. After two or three weeks growth the appearance Imesented ly the tulue is that of al layer of liquid at the mper part. and the growth along the needle trate with the other alpeanlances described at the bower part. The liguid portion is elear, except at the hottom of the liegnid. where there is a lowse white Hocenlent depesit of bareilli, and on the surfice there mily le a very thin selum. The liepuid beeomes yellowish in eolour after a time and

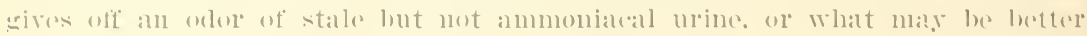

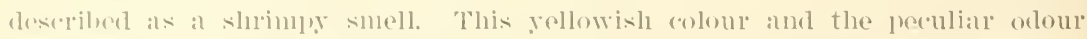
hatre been found ley. Mr. (Cheshire to be distinctive of the diseased larvae.

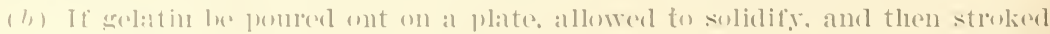

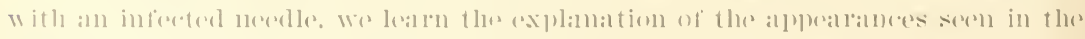

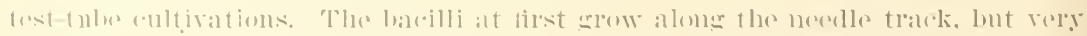

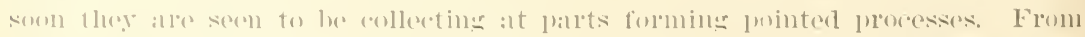

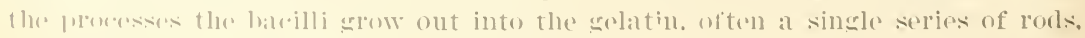
in Indian tile, or two or three rock side by sicke. These processes are not quite 


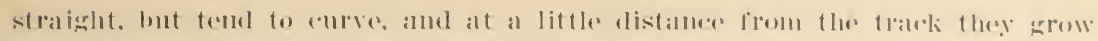

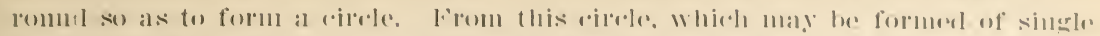

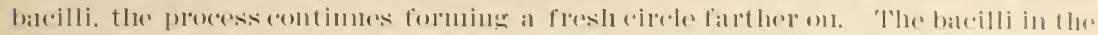

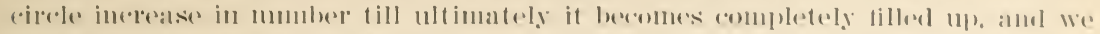

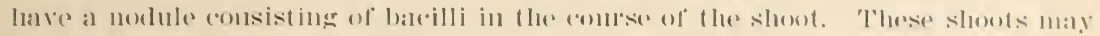

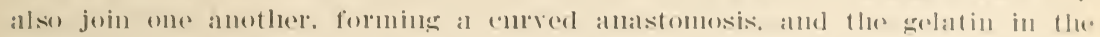

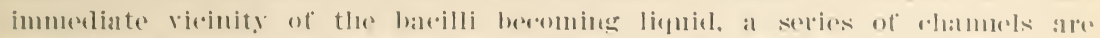

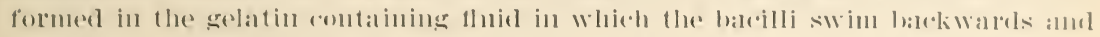

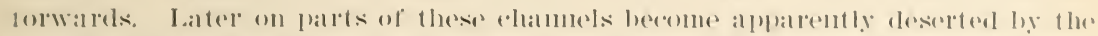

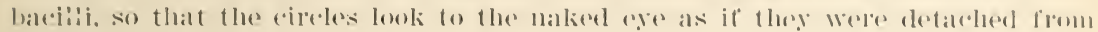

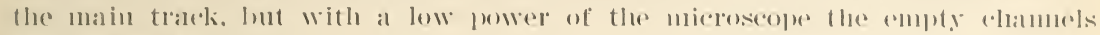
rill be traterel.

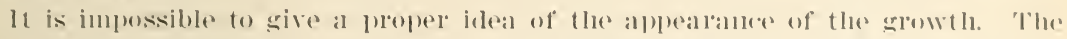

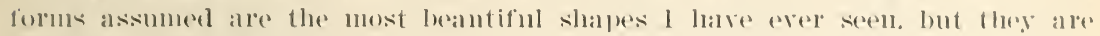

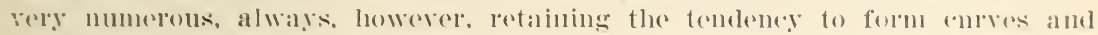

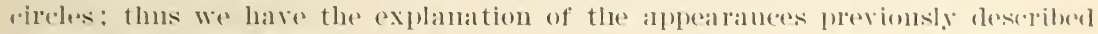
in the test-tube enltivations.

(1.) The appealances of the eolenies on plates on which the mixture of

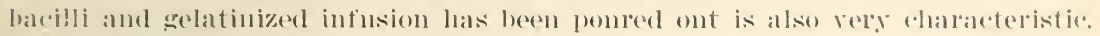

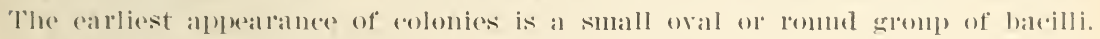

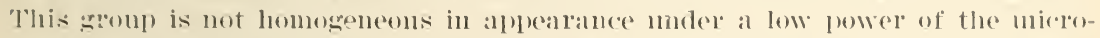

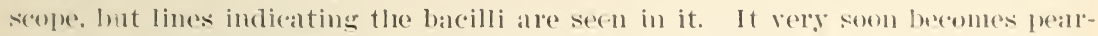
shapeel, and from the shalp end of the pear ploeesses begin to pass ont info the selatill as before aleseriberl.

'These bacilli do not arow below $16^{\circ} \mathrm{C}$. The best growth in gelatiu is obtained at a temperature of about $20^{\circ}$ C. They grow most raprelly in cultivating materials lept at the body temperature. Very few sleores are formed at tle lower temperatures. but tley appear lapielly and in large numbers at the boely

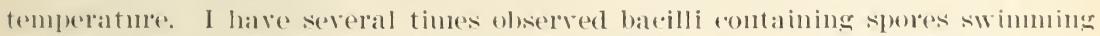
about freely. "Phe reaction of the medium is not of any great importance, hut a neutral medium is alparently the best. The bacilli swin freely in fluids with a slow os

'They grow rapidly at the body temperature in meat infusion with peptom and rendered solid by agar-agar. but the alpearance of their srowth is not nearly so characteristic as in gelatin. This, incleed, is tle ase witl most bacteria, so that agar-agal preparations, though very nscful for carryiug ou jure cultivations at the temperature of the boly. are of little value for diagunstic purposes. Thẹ grow most rapidly on the surface of the agar-agar. fornine a whitish layer. Int the shoots described above in the ass of selatin

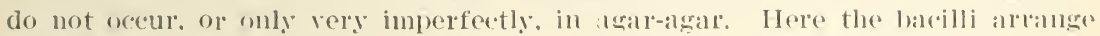

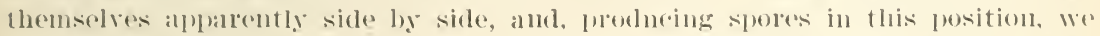
have as a result, after a fow days cultivation. long rows of spores lying side by side with here and there an abult bateillus.

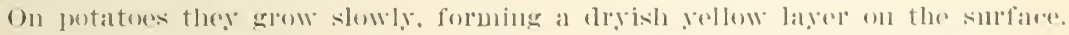

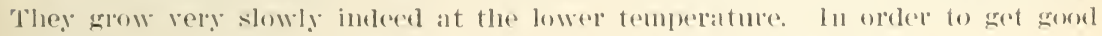

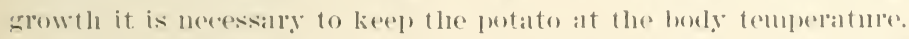

In milk they grow well at the hody temperatme. and in a lew days cease coagnlation of the nilk. Which also assumes a yollowish eolom and gives off the

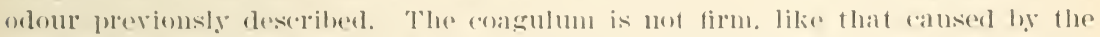
Barerermm laretis, mot is like a tremuloms jelly, and may remain for a romsider-

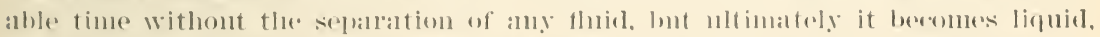

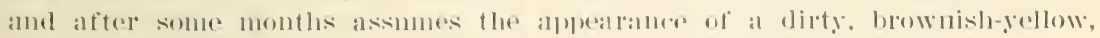
glairy Huid. It is very slightly, if indered at all. acid.

$30547-\mathrm{T}$. $70-0 \mathrm{~T}-3$ 
They grow atremely slowly in coasulated blood serum, thomell kept at the

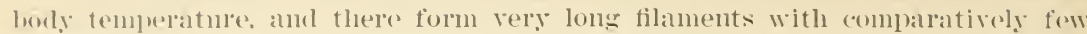
ㄱores:

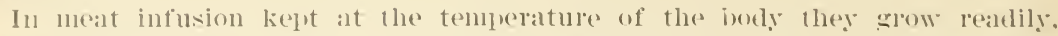

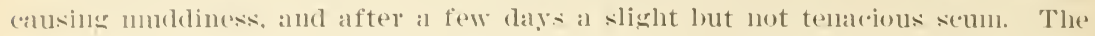
same prouliar odor is also developed here. more expecially if the infusion contains a considerable anomnt of peptome. I do not think that there is any change in the leatetion of the fluid; I generally make the infuxions faintly alkaline. and after the srowth of this organism in it it is faintly allatine.

'These dhallatelestics show that this is a new bacillus, and one which, so fall as $11 y$ linowledge and experience goes, is only found in foul broot. 'The coustant presence in lanere mumbers of a characteristic organism in a disease and its absence olsewhele must, accolding to our accumulating experience, afford a strong formuption that the organism is the cause of the disease. In the case of foul hrood this matter has been completely proved by the following experinents. the details of which will be found in Mr. Cheshires part of this paper. With a cultivation in milk he sprayed a comb containing a healthy broorl. allowing the spray to act onle on a particular part of the comb. This part and no other became affected with foul brood. II has also succeeded in inferting alult bees by feeding them with material containing these cultivated bacilli.

I have also had the oplortunity of watching the effect of feeding flios with material containing spores and bacilli, I was one day testing some milk in which these bateilli were growing; a large blue-bottle fly settled on it and commenced to ait. I at once put a large glass fumnel orer the insect. leaving plenty of air. When I came to the laboratory twenty-four hours later. tle fly was in the sitting posture on the table and was dead. Its juices were full of these bacilli, as shown by nicroscopical examination and by cultivation.

Other animals which I have tested are more or less refractory to this bacillus. I have kept cockloaches for days in a box in which was milk containing these bacilli mixed up with sugar. I have also kept them in a box containing a piece of paper which had been thoroughly smeared with the spores. None of them died, but I can not be certain that in either case they ate any of the material. for I wever saw them even near it.

I inoculated two mice and one rabbit with a spore-be:iring cultivation without efferet.

I injected half a siringeful of a spore-bearing cultivation into the dorsal subcutaneous tissue of each of two mice. One of these died in twenty-throe hours, the other seemed unaffected. but in the second ase I doubt whether the full guantity was introduced. In the ase of the mouse which diect. the seat of injection and the neighbouring cellular tissue was found to be very ardematous, but no microscopic chances were aplatrent in the intermal oraans. Numerous bacilli were found in the cedematous fluid. as also a number of spores which had not been sprouted, and there were also a fow bacilli in the blood taken from the heart. This was proverl, of eomse. by cultivation as well as by nicloscopical examination. On examining sections of the varions orrans no morbid changes were found, and only very few bacilli were seen in the blomd ressels.

It the same time that I injected the mice I injected a syringeful of the same cultivation subentaneously into a suinea pis. This animal died six days later with oxtrusive neclosis of the muscular tissue and skin and rhesy-lowking batrhes distributer through it. There was no true pus. On making sections of the necrosed tissue numerous bacilli, apparently Bacillus alrci, were seen, 


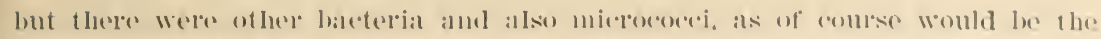

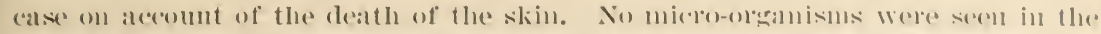
internal organs. It thus remalns questionable whether the nerelosis was due to the Bacillus aleci or not, more esper ially as I have sines injected there

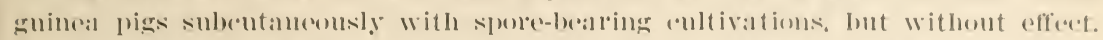
I must reserve the atetion of these bateilli on the higher animals for funther

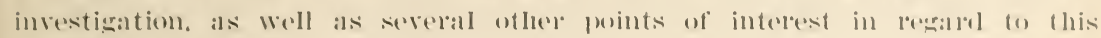
or:aimism to which I have not here alluded.

I ventume to think that when all the evidence bronght forwall by . Mr. ('hesshire and myself is anrefully weighed no dombt ean be entertalined that this

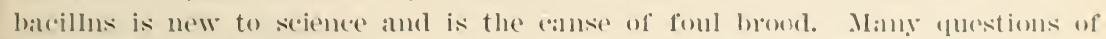
course still remain open, resuiring further investigation inte the life history of the discists.

The next investigator to take up a bacteriological treatment of bee diseases was Prof. J. J. Mackenzie, batererologist of the provineial board of health of Ontario. The results of this work were published in the Ontario Agricultural College Report for 189.2, pages 2fit-27:3. At the request of the Bee Keeper's' Union of Canada certain things: were taken up which had a rery practical bearing on the question of eradicating the prevalent disease.

Profesor Mackenzie knew of but one disease, probably, and haring in hand the work of Cheshire and Cheyne, assumed that the disease found in Canala is the same as that described by Cheyne. This is a natural mistake after the confusion in the diagnosis by Cheshire. It was not the object of this investigation to demonstrate what organism produces the diseased condition. but, assmming that Bacillus alvei causes the trouble, to determine what resistance to heat the organism has.

No adequate description, such as would allow us to make any comparions with Barillus alcei, is included in Professor Mackenzie's paper. We do know, however, or at least have every reason to believe. that European foul brood was not found in Canada at that time and is not prevalent there now. I have been informed personally hy Mr. William Mekroy, the reteran inspector of Ontario, that the disease which we now designate as American foul brood is the prevailing discase in Canada. It seems reasonable to suppose, therefore, that the samples taken to Professor Mackenzie by Mr. Holtermann and others dicl not contain any Barillus alvei.

Profesor Mackenzie does not indicate in his paper that he harl any difficulty in getting the organism with which he worked to grow on ordinary media. Barillus larer. which is present in American foul brood, does not grow in such media, howerer, so there is but one conclusion to be reached, and that is that he was dealing with some nonpathogenic form and not with Bacillus larees. Since the bacillus described by Doctor White as Bacillus $A$ is fommd on combs. both diseased and healthy. and somewhat resembles Bacillus alcei, it may be that this is what Professor Mackenzie had. 
This paper has probaluly come to the notice of but few bee keepers in the Inited states because the report of the agricultural college is not widely distributerl. To make it a vailable for comparison, therefore, it is included here.

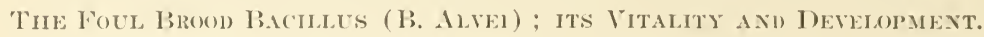 [From Ontario Agricultural college Report for 1s92, pp. 2067-273.]}

Mr. J. J. Mackenzie, I3. A.. bacteriologist of the provincial board of health of Ontario, read the following palper :

(iExtlemex: At the request of your secretary, Mr. Iloltermann, I undertook for your union some investigations on the subject of foul brood, the results of which I propose siving you in this paper. Although it is almost a year now since I undertook this work under the auspices of the Agricultural and Experimental Union, it is by no means exilausted. and there are many points which reguire to be further elucidated, which I have not had time as yet to touch on. owing to the fact that investigations on foul brood had to be carried on simultaneously with my regular laboratory work. These points I hope to work at next summer, and reserve the privilege of reporting again to your union on the results of further investigation.

The subject of foul brood is an old one to apiarists and an intensely interesting one to Canadian bee keepers, but in reading over the bee journals one can not help being struck with the great want of unanimity amongst bee men as to the disease, how it shonld be treated, how it is spread, and on many other points. some would have us believe that the disease arises de novo whenerer insanitary conditions prevail; others claim that there is a specific infection and where the diseatse arises it must have originated from previously existing disease: some c. laim that the honey is the only method of tramsmittal ; others that it is not, and so on. On every point there seems to be plenty of arguments pro and con.

I lave attempted in my work to take hold of some of these controverted points from a bacteriological standpoint in order to aid in coming to some definite conclusion. Some of these points I should consider settled from the results of previous investigation; but as many bee men do not seem prepared to accept this, my work will have value as confirming what has already been done.

Iefore an association which includes many practical bee leepers it wonld be superfluous to enter upon a minute account of the clinical features of the disease. Inst of you know them better than I do. I certainly would not he prefared to "spot" foul brood in an apiary, although I certainly think I can under the microscope. The infectious character of the disease has been senerally accepted for many years, but not until Cheshire and Watson cheyne worked it out scientifically was it definitely proved. They isolated a barcillus (Bacillus aleei) which they found in the diseased brood and which they rultivated on nutrient media for many generations, finally reinfecting berfectly healthy brood from these pure cultures. This evidence to a bacteriologist is alsolutely conclusive that Bacillus alrei is the specific callse of foul brood. Consequently, when I began my investigations on some simples of disealsed brood which were sent me through Mr. IIoltermann, I looked at once for Bacillus alrei. Microserpically and by means of haceteriologrical methods I had no ditliculty in isolating

bicillus which corresponds in all points to Bacillus aleci. It is a bacillus similar to that of "heshire's in si\%e, produces spores which alre somewhat thickere griving the bacillus a clubhed appealrance. On agal jelly it grows rapidly so as to corer the whole surface. In gelatin its growth is very peculiar, shooting vut from the infected point in all directions. On potatoes it produces 


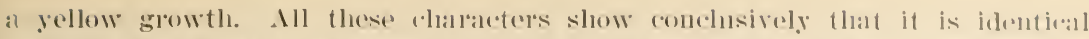

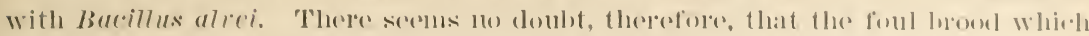
we have in Gutario is the same diseatse and produced by the same bateillus as in other plates.

Many prominent bee keepers, both lere and in the states, howerer, matintain

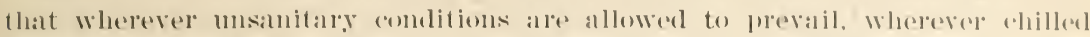

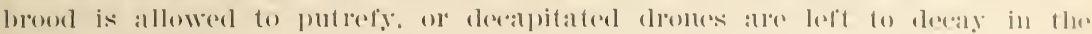

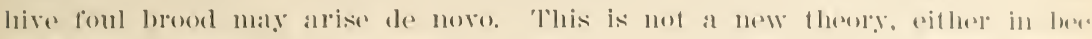

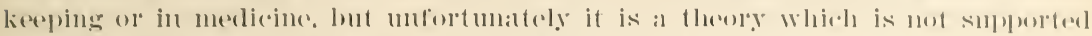

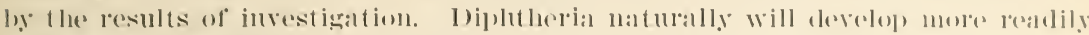
if minsmitary conditions are present, but it certainly will not dovelop if the Bureillus diphtherier is absent. 'The same is true of other discases, and andsequently when we come to eonsider such a decidedly inferetions diseatse as foul broed and lealrn the fatets about it which such men as cheshire have tohl us we naturally eneme to the same eonelusion. If I were to maintain that a carniol:an queen might liy an egg which would develop into a humble bee, bee men woulal be inclined to think that not only my bee knowledge, but also my seiplntitive knowledge, was at fault; bnt yet in all the bee jomrnals I find many promi-

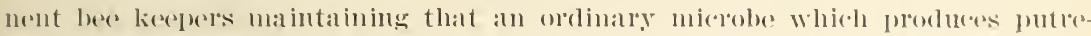

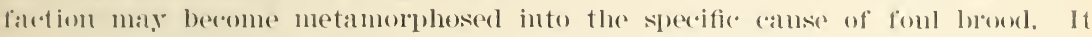
it is aasy emough, lowever, to combat such an opinion mpon a priori grounds. but not (juite so easy to offer convincing proof.

In order to do this I thought it wortle while to try some experiments. With this end in view I obtatined some eomb containing chilled broes and endeatvored (1) isolate Bucillus alce ifrom it, but without sucress.

There wore plenty of other bateria, but none which presented the wellmarked morplobogical character's peculiar to Bacillus alvei. Igain I lad sent to the laboratory a piece of perfectly healtly comb. I killed the brood by aldilling. Then I infected some of the cells from a pure coulture of Bacillus allei. I allowed all the chilled brood to putrefy in a moist chamber for two weelis, at the end of which time I obtained Bucillus alvei again from the colls which hatd been artificially infected, but could find no tratees of it in the other ands. I left this comb in a moist clamber for several months and again examinod. but with the same results. In the cells in which Bucillus alrei had been platced it wals still to be fomd; in the others it was not present.

It seems to me that an experiment such as the above conchusively shows that there is a distinct difference between foul bood and ordinary putrefaction.

In considering the subject of the vitality of Bacillus alrei the first puestion which naturally arises is its power to resist leat. We know that baldilli which produce spores and those which do not stand in entirely different positions in this regard. The sporeless bacillus is destroyed at a much lower tempriature than one which contains spores. Consequently in consiglering the question of the vitality of Barillus alcri, which produces spores very enickly and casily, we may confine our attention entirely to the vitality of the spore.

This is of special interest, as the question has been repeaterly raised whether it is dangerous to use comb foundation made from foml-broody wax. Does the temperature to which the wax is raised in the matmlateture of comb foundation sufficiently destroy the vitality of the spore? Can the spore germinate and infect the brood when once inclosed in the wax?

These questions have been raised by many areful thinkers among bee men, and certainly deserve attention. The sexond point ought to be considered first. since if surfounding a spore with a film of wax forerents its gremiuation, we need pay no further attention to the question of heat. 'The crucial test of this 
would naturally be supply a lealthy colony with eomb foundation known to contain the spores and observe the result. This I had hoped to try with the assistance of your socretary, but other work came up which interfered with the carrying out of this experiment and conseduently it had to be postponed until next year. However. I was alble to perform one experinent which throws some lisht on the sulnjext. Mr. Iloltermann, the sereretary of your union, sent me sereral pounds of very fine wax, such as is used for the manufacture of connl, fommlation. I cultivated the Bareillus aleei upon agar jelly until I had a latere quantity of the hadeilli containing sporess this was calefully scrapred off the jelly and dried first in the air and then orere sulphuric atcicl. The resulting grayish mass was pulverized with a sterilized pestle and mortar, and finally mixed thorouglny with the melted wax kept at a temperature sufficiently low to prevent the inmediate destruction of the spores by heat. Py this means an enormous number of spores were introduced into the wax. After stirring the wax for some time in order to insure a proper mixing it was allowed to cool. This, as you all linow, takes some time when dealing with a considerable quantity. During the cooling I was careful not to disturb the wax.

Ifter it had solidified I set out to discover if I could again obtain my bacillus from the infeeted wax. If it would germinate in the nutrient media. it rertainly would in the bees, and that point was to a certain extent settlerl. Now I obtained the following results:

From the upper layers of the infected wax I was unable to obtain cultures of the Bacillus alcei, either by melting the wax in the nutrient jellies or by allowing particles of the ummelted wax to fall on the surface of these jellies.

From the under layers, howerer, the results were different; particles of wax placed on nutrient agar in an oren kept at $98^{\circ} \mathrm{F}$. Decame surrounded in twentyfour hours with a luxuriant growth of Bacillus aleri. When the wax was melted into the agar or into beef tea, I also obtained the bacillus, consecpuently it looks as if the mere fact of enreloping the spores with a film of wax was not sufficient to prevent germination. I confess I can not understand how a sporc could germinate when surrounded with a film of wax. Spores in germinating require moisture, and if a spore is completely embolded in wax, it ran not oltain sufficient moisture to germinate; I would rather believe, therefore. that in this particular experiment the spores hald not each an envelope of wax, but that many of them were partially free from wax. Yow, if this was the case in my experiment. where I endeavored to make the ineorporation of the spores in the wax as thorough as possible, I certalinly think it may frequently be the ase when foul-broody wax is used and no particular predaution taken. That eren when spores are thoroughly surrounded by wax they may not be freed oreasionally ly the workers is a point which requires further elucidation and upon which I intend to try some experiments next rear.

In looking through the bee journals, howerer, I find it everywhere maintained by foundation makers that they never knew of a case of foul brood origrinating from foul-broody wax; and I have yet to diseover a well authenti(ated case where this has occurred. What explanation can we offer of this widlespread opinion?

I explatined to you above that I was unable to eultivate Bacillus alrei from the npper layer of the infected wax. Your seceretary also sent me a small specimen of wax which he stated he knew to be from foul-brooly comb. This 1 examined repeatedly for foul brood, but was able to obtain it only onee. I think we must look to the physical conditions for an explanation of the freedom from infertion throngle comb fomndation. The difforence in, the sperifie grarity of the hacteria and of melted wax is so great that throughout the 
process of mamnfacture the bateterial temel to fall to the bottom. The first refining of the wax must, of eomese, remove the greater funthtity, allut the vast majority of the remaincler will settle to the bottem during the process of fomblation manufacture. But that the simple process of mixing the infereter material with the melted wax is not sullevent to provent germination I think is shown by the results quoted above. Where simple frasuments of infereterl was

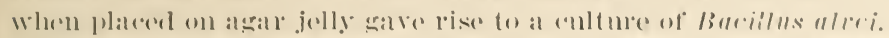

This question I hope to tonch on again after l have had an olpertmity of suppleing healthy leses with fomblation made from infected wax.

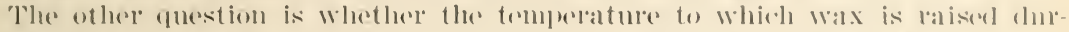
ing fomblation making is sufticiently high to destrog the spores of foul brood.

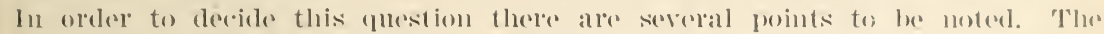
tirst is the charaleter of the heat. We know that moist heat will destroy batr-

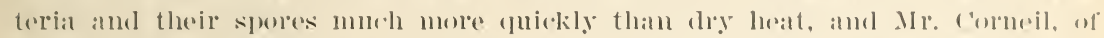
Lindsay, has raised this point sereral times, claming that the heat to which

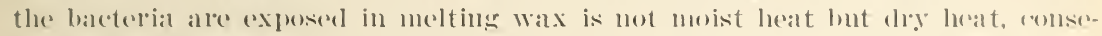
quently we must heat to a high temperature and for a long time in ordere to drestroy the spores. The point is moloubtedly well taken, and can only be settled ly direct experiment. In order to determine the temperature at whide the speres are destroged in melted wax, 1 used a method that was first described by Koch. Sterilized silk threads were saturated with a bef-tea culture of Bar-illus: alci in which there were large numbers of spores. These threads were then allowed to dry and in the dry state were preserved. These dried threadis wore introluer into the melted wax and allowed to remain in it for a definte time at a fixed temperature. At the end of that time the thead was intruluced into the melted agar or into heef teal heated to the melting point of wax, and thoroughly shaken, so as to sepalrate the wax as much as possible from the threats: then the rulture nedium was rapidly aoded, and the tubes plated in the ordi-

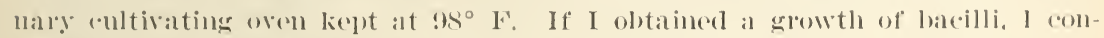
reluderl that the threats had not been sufliciently heated in the wax: if I dirl not, I concluderl that they had been sufficiently heated. 'The following an my results:

At $21: 2^{\circ} \mathrm{F} \cdot\left(100^{\circ}(\mathrm{r})\right.$ :

For one-puarter of an home: Growth.

For ome-half an hour: Growth.

For one hour : Growth.

For one hom and a half: (rowth.

For two hours: (riowth.

For two lours antel a half: No growtle.

At $194^{\circ} \mathrm{F}^{\circ}\left(90^{\circ}(\mathrm{)})\right.$ :

For one-half hour: Growth.

For one homr : Growtlo.

For two hours: (xiowtle.

For three lomis: No growtle.

For four lours: No (irowtlo.

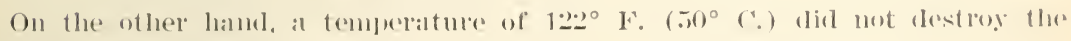
spores in twonty-four honrs.

I have repeated these experiments sererall times with the simme results. so

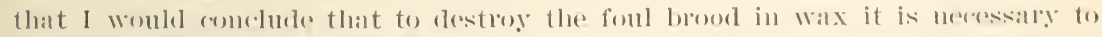
lieat to a tomperature of at least $194^{\circ} \mathrm{F}$. for al least three hours. Now the

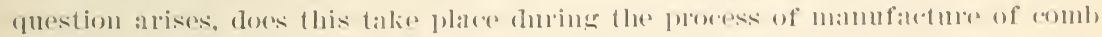
foumlation? In oreler to set as murele datal as possible on the subject I wote

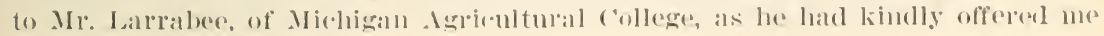


any assistance in his power. He applied to two prominent foundation makers for information. From their replies it is apparent that, for al short time al any rate, during the refining and purifying of the wax it realehes a temprerature

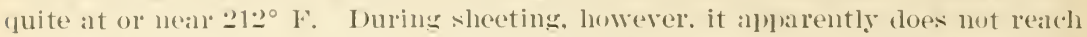
a temperature much alove the melting point. say $175^{\circ} \mathrm{F}$. They both seemed to agree that stean leat for too long a time injures the quality of the wax.

In the Amerian bee Jourmal, 1s!)1. paga tio, we find some statements on the sulject in a reply by two prominent foumlation makers to an article ly Mr. Cormeil upon the dangers of infereted eomln foundation. One of them, Mr. Dadant, states that in refining it is heater for sone time at 2120 F. and is liept liquid for twenty-four hours. The other. Mr. M. H. Hunt, states that it is kejt at the boiling point for six or seven hours. If these are the dietual temperittures reached during foundation making. I am inclined to think there is little danger from foul brood in that direction.

I thought it possible that the whole question could be settled by introducing a certain amount of some disinfertant - say beta naphthol-into the melted wax. lut my results have not been satisfactory. Apparently even the introduction of 1 per cent heta naphthol into wax did not hasten niaterially the destruction of the spores. I was able to demonstrate the presence of living spores in wax containing 1 per cent beta naphthol and heated for two hours to $194^{\circ} \mathrm{F}$.

From all these facts. and taking into consideration also the physical fact of the settling of the bacilli to the bottom. I should think that with reasonable care in the preparation of comb foundation the dangers of infection from this source would be slight. But that the spores may germinate after being mixed with the wax. I think I have shown.

Why the spores of the Bacillus alvei are killed so quickly in the melted wax I am not able to explain. but it may be due to the fact that the wax itself when heated to such a temperature has an antiseptic ralue. That the spores resist other antisepties as strongly as do the spores of anthrax I have proved by testing.

Cheshire and other's recommend a solution of 2 per cent carbolic acid for disinfecting the hive after remoring infected comb. but on actual experiment with the infected silk threads I have found that 2 per cent carbolic acid did not kill the spores in six days. These results are similar to those obtained by Koch for the spores of anthrax, and show that 2 per cent carbolic acid can not be relied on to destroy the spores. Howerer. the question of the value of antiseptics I will take up more in detail later on in this paper.

I would like to say a word or two now on the methods of treating the disease. There are practically two methods: first, the starvation method; second. the method of medicated sirup. Mr. McEvor's method of treatment. it seems to me, is practically a modification of the starvation method. The first method is widely used hoth here and in the Inited states. whilst in England and Europe generally the sorend method is adhered to.

considering the vitality of the spores of foul brood. it would seem at first sight usceless to try any process which did not recognize as its foundation the destruction of the germ. I find. however, that many prominent bee leepers who have had pratetical experience with the method of starvation. or Mr. Mrevoy's method, accept it as successful. I have not had an opportunity to examine (oolonies which have been emerl in this mammer. and so (am not saly that the bacilli have disappeared. I hope next smmmer to test this fuestion more fully. We may, howerer, eximine into the rationale of the method. In conversation with $\mathrm{Mr}$. Colmeil. of Lindsay, he made a sugrestion which may be quite familiar to you all, but which seems to me the only explana- 


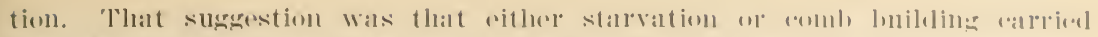

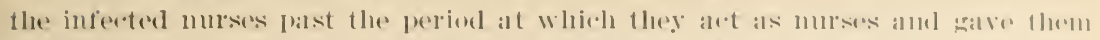
at chance to rid their infestines of the germe If this is anmbined with al

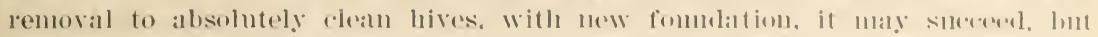
I must saly that absolute relemliness in this respert must be insisted ond. As I salid above, I have not latel amy opportmity of investigatting the results

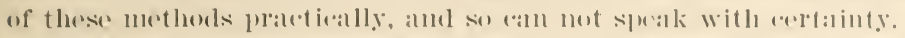

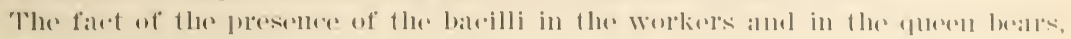

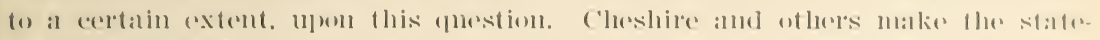
Inent that the bateilli are found in the intestines of the worliers and in the ovaties of the queens. My own experiemee comtirms this. I have fomml flum

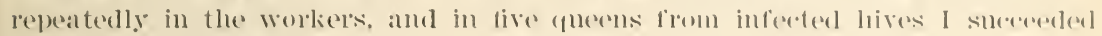
in obtaining the bateillus from the ovaries of there. Fhat lhey alle mot alwalys

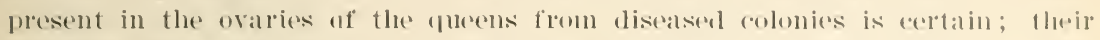
presence there is apparently aredelental. For instance, in the ease of ond last reatr's queens in a hive rather batlly diseatsed I wats mable to find the bateillus. whilst in a six weeks" fueen from a hive in which there were only a few disabsed cells I succeeded in finding it.

Cheshire's statement that he found a hacillus in an eger of an infected dneen seoms to me to require (onfirmation. I have not leen able to find the afers infected myself, but it is a question which womld repuire rery long and anceful investigation before one could be able to deny or confirm such a statement.

In the serome method of treatment by medieation I do not think that al: absolute destruetion of the spores takes flace, any more than in the starvation method. As I have shown above, 2 per cent carbolic ar.id was mot sufliciently strong to destroy the spores, consepuently it is not likely that 0.2 per rent 1 lat in 500 ) would be strong enough. I tried 0.2 per cont, but found it quite unsucessful. Its artion then must have another explamation. 'To test this I made up a sterilized beef broth containing 1 per bor of calrbolic aciel, and in it plated my infected silk threalds. I found that there was no indiontion of growth. These threads were then taken out and placed in ordinalry strrilized heef broth, and I obtained a luxuriant growth, i. e., the 0.2 per ant artorlic acid in the culture Huid, although it did not destroy the spores, prevented their germination. That, then, is the explanation of the value of "arbolated sirmp in the treatment of foul brood, it prevents the germination of the spores. 'The bee journals contain numerous eximples of (ases where (anloblated sirmp produced an improvement, but as soon as it was stopled there was a relapese. It is evident that here again, as in the starvation process, there must be combined an extremely thorough (eaming up). so that the best possible results may be obtained from the treatment. Medicated simp does not destroy the spores, it simply prevents their derelomment and gives the bees a elatuce to rid themselves of the infection, and in that respecet I eertainly think rexembles the starvation process. Its advantage over that is that it ain lee carried on for ¿longer time.

In the course of these experiments I tried amother sulstance which has been much used since Lortet's work on the subject, vi\%, lyeta nalphthel. I de not think myself, from recent work on this sulstance, that heta nilphthol shonlel loe ranked rely high as an antiseptic, mainly on aceomt of its insolubility in water. I fomm, however, that a beef broth containing 1 jer 1 ,oou botal naphthol would not allow spores of Barillus alwei to germinate, and conserfuently

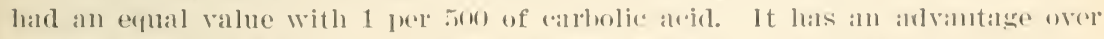
"arbolic aleid on acenunt of the disagreeable taste of the latter, and I think would be more acceptable fo the hees. 
Salicylic arid in sirup has apparently the same effect. but I would not recommend the addition of borax, as Behring has shown that borax lowers considerably the antiseptic value of salieglic aceid.

I tested also formic acid in the salne way, but my results so far lave not beens sitisfactory, owing to the uncertain strength of my simple of formic acicl. I prefor to reserve a report upen it and other substances which I wish to try until litter.

Mrer'uric chloride I have not tested. as I do not think it wise to use it around the hive. The ideat of using a 1 leer 1.000 solution to splaty the diseased combs. as sugrgested sometimes, is, I think. absurd, and would be a rather serious operation for any living brood.

lou will see that I consider all these methods of treatment do not in themselves necessarily presuppose the destruction of the spores, but depend upon the fart that for a longer or shorter period the spores are prevented from germinating. and in this period they are eliminated from the infected boes. Whether the vitality of the bees themseives has an effect upon the elimination or destruetion of the spores is a point which would be extremely interesting, but one on whicll at present we lave no definite information. From the results of bacteriological work on other diseases we know that the animal boty is engaged in a ronstant warfare with the disease germs which may be introduced, and this also may be the case in foul brood. Much more extended investigations. howerer. would be necessary to prove this. It is much safer for apiarists to accept the possibility of a recurrence of the disease after a course of treatment. owing to the lodgment somewhere of some of the spores of Bacillus alrci. ant by care and cleanliness remove this possibility. To do this the hives and frames in which a foul broody colony has lived must be sterilized. and this may be done in rarious wars. For the sterilization of material by disinfectants there was a tendencr formerly among bacteriologists to rum to such disinfectants as corrosive sublimate, carbolic acid, etc.. but later work has shown that there are a number of common chemicals which will act just as well, or perhaps better. Corrosive sublimate has lost much of its reputation as a disinfectant within the last few rears. and arbolic has been shown to be not nearly so powerful as at first supposed.

For cleaning hives and frames which are suspected to contain the spores of fonl hrood a lot $10 \mathrm{per}$ cent solution of soft soap is perhaps as effectual as any that can be recommended. A good strong solution of washing soda. when hot, is also very active, destroying the spores in a few minutes. Both these are "ertainly better than 5 per cent carbolic for disinfecting the hives and frames, as their cleansing properties are so much better than it, and Peluring has shown that joer cent carbolie requires at least three hours at blood heat to destroy the spores of anthrax. In case the solap or the washing soda is used. howerer, it mist be used as hot as possible. Of course anything which is of no value should be burned.

I trust that in this paper I lave thrown a little light upon some of the facts in comnection with the disease of foul broot. lut, als I staterl in the beginning. I reserve the grivilege of submitting to ron at a future meeting the results of next summer"s work.

Ibefore elosing I desire to express my thanks to your able secretary. Mr. loltermann, for the assistanee which he lats given me. and also to Mr. Corneil. of lindsaly for atriese and for the use of volumes of all the principal bee jommals. which he has supplierl me with: also to Mre. Larrabere of Michigan Igricultural college. in cennection with the subject of comb foundation. 
The next investigation to be considered is that hy Prof. F. ('. Harri

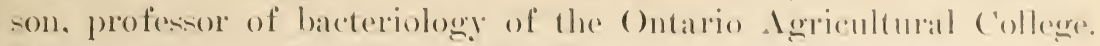
Previous to this Dr. William R. Howald published a papere on the subject. but this can be discoused better at a later time. In the palpere by Professor Harrison, previonsly mentioned, the anthor given a detailed description of the batcillus with which he worked. The description is as follows:

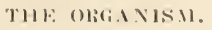

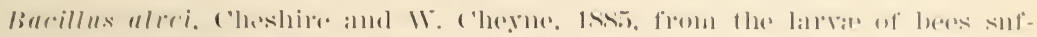

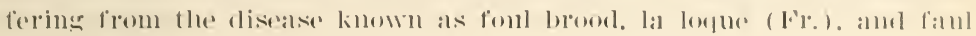
brut 1 (ine).

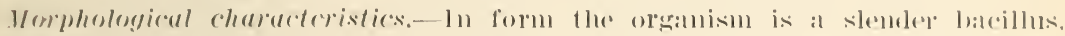

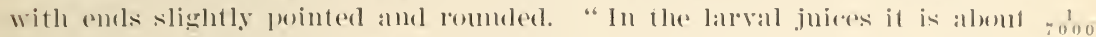

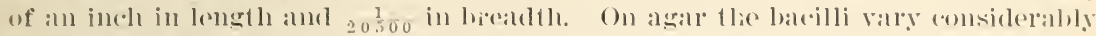

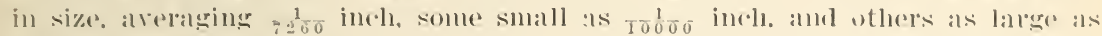
3000 incle. When they have attained the latter size, division of the lod serme fo

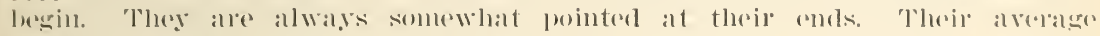

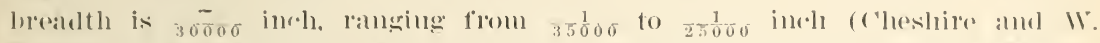

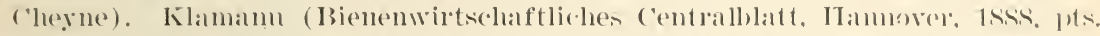
1. anc 1!) states that a clear space often appeals in bareilli with pointerl ends.

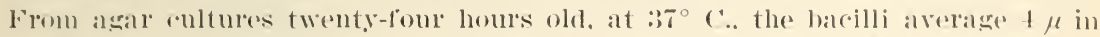

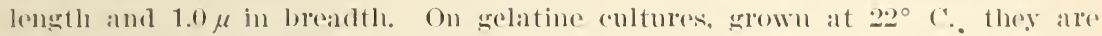

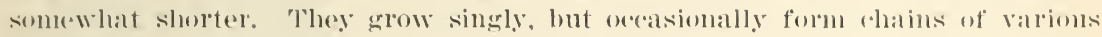
lengrth.

stains. With the orolinary aniline stains the bateilli colom rather batlly

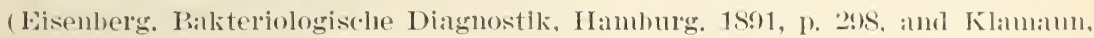

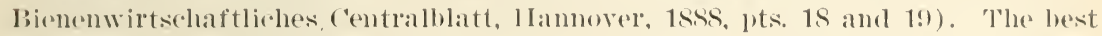
stains are methylene lolue and metlyyl violet. The bacilli aceept Gram's staill. lut the sjores are not rolored by it. I find the most satisfactory stall in motloyl violet.

('apsule.- No (:apsule has been demonstrated by Welch's method.

Flugellu.-The bar.illi are actively motile and possess a single Hagellum at ome pole. The motility of the bateillus is yuite promomeed in fresle cultures obtanined

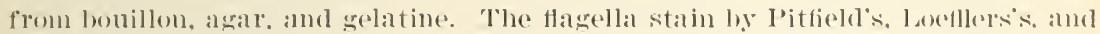
V:all Ermegents method.

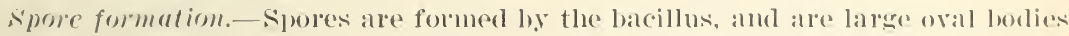
averaging in length $\frac{1}{12000}$ inch. and in breatth $2 \frac{1}{3} \frac{1}{60}$ of all incll. On agar the spores are arrallged in long rows. side by side, and are greater in diandeter tliall the (eells foom which they are derived. The earliest alpeatrance of slore forma-

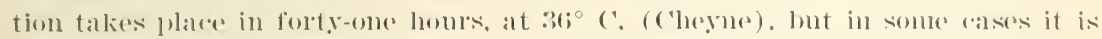

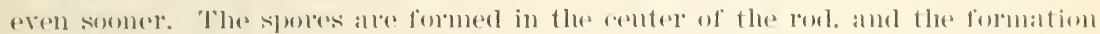

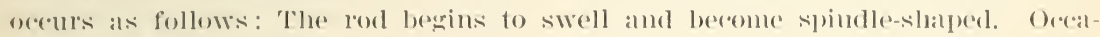

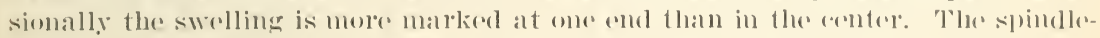

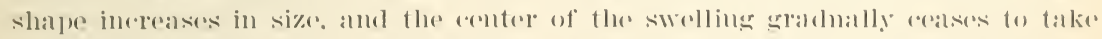

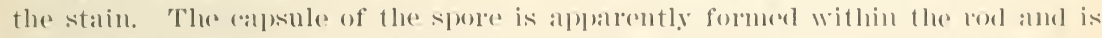

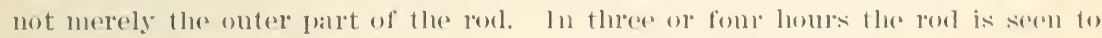

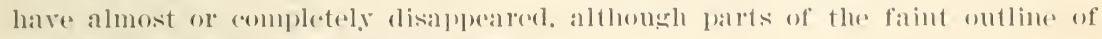
the orelinary hateillus maty be noticent.

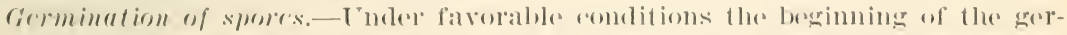
mination of the spores takes place in about three hours. 'l'he spore loses its oval 
shape, hecemes eloneated, and is soon seen to burst through the spore capsule. It then presents the appearance of a short red, with a pale convelope embracing whe and. The rod gradually leaves the spore capsule, and then goes on multiplying ats a full-grown hacillus. Acording to Eisenberg (Bakteriolosische Diagnostik. Hamburs. 1s!l1, p. 2us) the spores are dereolorized by the tuberele

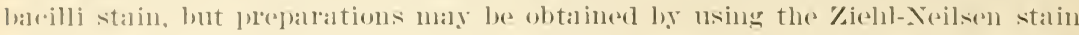
ancl aleoluel for decolorization. 'The spores also stain ly the method of Neisser.

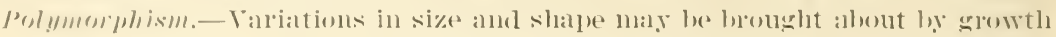

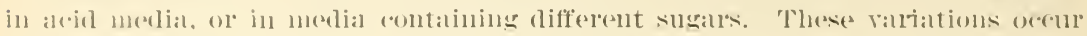

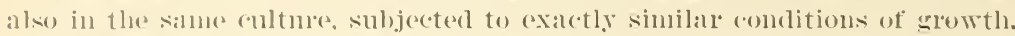

Ineolution forms.-Abnormal forms alle especially alsmelant when the bacillus is srown on blood serum; peculiar Y-like forms and clubbed shapes are of common occurrence, and relatirely fer spores are found.

\section{BIOLOGICAL CHARACTERS.}

Bonillon.-"In meat infusion at the temperature of the body they grow rapidly, causing muddiness and, after a few days. a slight but not tenacious scum" (('heshire and $\mathrm{IV}$. ('heyne). In boullon. with a reartion of + o.os (report of convention of American Pacteriologists. Jomrnal American I'ublic Ifealth Association, Vol. XxiII. 1898), at $37^{\circ}$ C., there is a slight turloidity in fourteen hours, esperially noticeable when the tube is shaken. In twenty-four lours. the liquid is uniformly turbid, with a rery fine sediment. In fortyeight hours the turbidity increases and a pellicle commences to form. Reatcion of the culture at this time, +0.07. After ninety-six hours the broth is clear. with a pellicle. white, rather massive, and somewhat tenacious. There is also much sediment. Reaction, after ten dass' growtl, neutral.

(ilycerine bouitlon.-Media with original reaction of to.0S. At $37^{\circ} \mathrm{C}$. the bouillon becomes slightly turbid in twelve hours and quite turbid in twentr-four. with a fine. whitish pellicle on surface, which does not extend to the sides of the tube. If the culture is shakell, the pellicle deposits in flaky masses. 'The reaction is +1.2. In thirty-six hours the turbidity clears, learing the media bright, with a smooth, thin, tenacious, and white pellicle on the surface, In many cases the pellice becomes rery wrinkled and sreasy looking. At the ent of eight dars the reaction is +2.2. and the boullon is several shades darker in color. but quite clear. 'The reatetion after fourteen day's growth is +4.2 . At $222^{\circ} \mathrm{C}$. the same rhanges ocrur, but growth is slower. The bacilli are relatively less numerous than in bouillon and are slightly shorter and thicker.

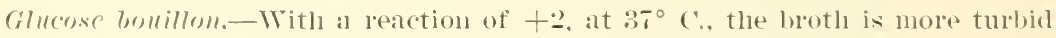
than plan houllon after fourteen hours growth: and in twenty-four hours the sodiment is heary and turbidity very marked, but no pellicle. In forty-eight hours the media is oplatue and clouly, and the pellicle is begimning to form. In ninety-six hours the hoth is less cloudy. hut the sediment is heavier. and a white, thick pellicle is formed. It is often wrinkled, hut not quite so much so as that on the glycerine broth. Reaction of broth after ten dass' growth, + t. The bacilli are oceasionally clubbed, and Y-like forms maly oreur. 'They arerage 5 $\mu$ in lengtls and may be slightly arvede

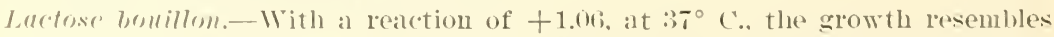
that of plain bonillen for the first twenty-four hours; but at the end of fortyaiglt hours, it is more turbicl. In minety-six hours, a tenar cious pellicle forms, less

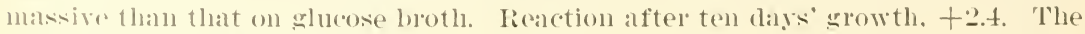
balcilli atrerange :3..5 $\mu$ in lensth.

surchurose bonillom.- With a reaction of +1 . at $: 37^{\circ} C^{\circ}$., the turbidity and serliment are heavier than any of the other bouillons. In forty-eight hemrs the 
broth is quite opalque and whitish looking. I heary serlinent is then porsent. and pellicle formation is just heginning. In ninety-six homes the efmuliness is about the same, but there is an incerease of serliment, and the pwhiche is thin ant

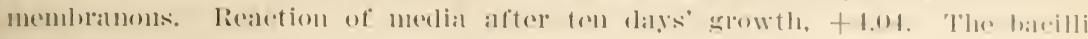
arerige $5 \mu$ in length.

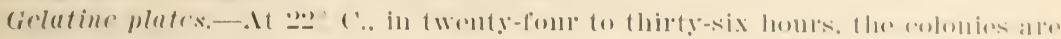

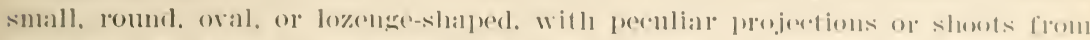

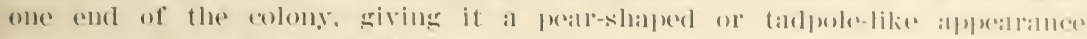

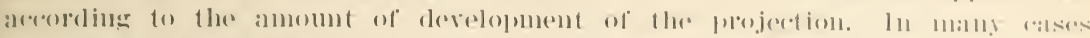

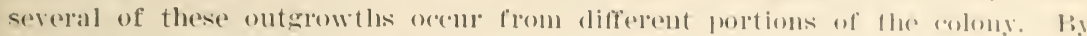

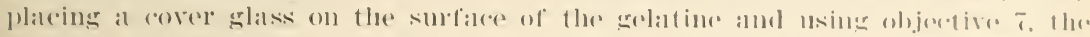

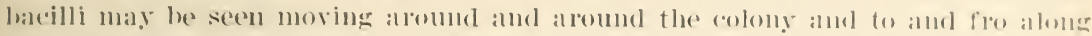
the projections. At the end of forty-eight homrs the rolonies alle linleres. Fine

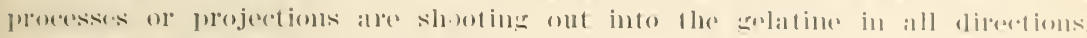
forming peruliar tigures in eireles or elub-like forms. "It is impossible." silys

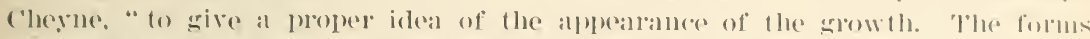
assumed ale the most beatutiful shaped l have erer sorol; hut they alle vers numerous, always retalining the tendeney to form curves and eireles." After it

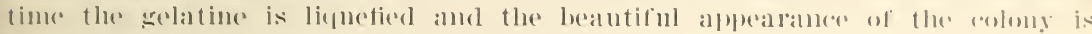
destroged loy the lipuefiation of the gelatin.

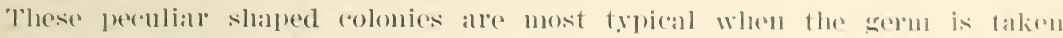
from the diseased larvie. Ifter prolongerl cultivation on vartons kinds of medi:

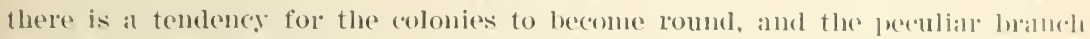
ing forms are net seen in such numbers. The eomposition of the gelattine also seems to make a difference in the appearanee of the colonies. In gedatine containing 12 per ernt gelatine the processes are not so long. Tlue salne cefferet may be brought about by using more peptone in the composition of the media.

Gelatine tubes.-In stick cultures at $20^{\circ} \mathrm{C}$. Growth ocents all along the line of puncture. On the surface delicate branching or limnifying growth oceurs in three disys. These outgrowths soon run together and the gelatine is lifpurfied, first around the line of puncture, and in five days extends over the whole surface. The growth in the depth of the gelatine orours as a whitish struili all along the needle track, and from this numerous shoots and growtls hanch out into the gelatine in all directions. griving a haziness to the alpearance of the gelatine. which then hegins to liguefy. If the inoculation is a heary one. the shoots are coalrse and may have (dub-shaped extremities, and from these

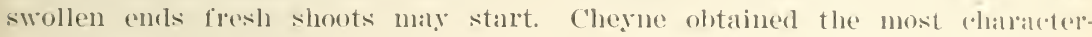
istic growth in gelatine containing 3 per cent of peptone as well ats 10 per erent gelatine. The whole tube is liquefied in from two to four woeks" growth. "The liquid becomes rellowish in color and grives off a peculial olor. Klamian states that in gelatin aciditied with lactic acid the growth is slow and long threads are formed.

Gelatine streak cultures.-In gelatine streak rultures the appearance is rery similar to what one sees in stick cultures. The bacilli first grow along the line of inoculation, and then throw out shoots into the smmomeling gelatine. por ducing the aplearance noted in the stick culture. The lateilli more to and fro alomg the chamnels of liquefied selatine.

Agar plates.-On agar plates at $37^{\circ}$ ( . the colonies at the emel of eight homs are small and burr-like, with spines potruding in all directions, giving the colony the appearance of a sea urehin. In some casce the projections alle from one side or end. At the end of twelve hemes the andenies hatre welldefined projections. visible to the naked eye. 'l'he enlonise in the depths of the agar are more spiny. the processes being much shorter. On agal plates 
strealied with a light inorulation most beatutiful forms oecur. The growth of the bacilli spreals orer the surface and branches repeatedly, giving the alpearance of seatreed. This alpearance is clistinetly charileteristic; and as the growth is rery rapid. this method comments itself for malking a quick diagnosis of the presence of the bacillus in larva supposed to be diseased.

Protuto cultures,-On protatoes the growth differs considerably, alcoreling to the reaction and age of the potato. Sometimes a brownish wrinkled growth forms, which grives off a peculiar odor; at other times a dryish yellow layei

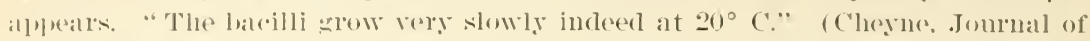
the Royal Microscopical Society, 1885, p. 381). Eren at $37^{\circ}$ C. they grow slowly.

Milli-In milk at $37^{\circ}$ C. coagulation of the casein occurs in three clars. The milk becomes gellowish and gives off a characteristic olor. After sereral weeks' growth the curd is digested and a whey-like fluid remains.

Blood serum.-On blood serum at $37^{\circ}$ C. the growth is rather slow and polymorphic forms are common. "Very long filaments are formed" (Cheshire and $\mathrm{W}$. Cherne, Journal of the Royal Microscopical Societr, 185.), 1). 381). These long forms may be from five to ten times as long as the arerage bacillus growing on gelatine, and consists of single cells. The filaments are often war or twisted and of unequal thickness. The extremities of the long. bent rods are often chubbed; and $\mathrm{Y}$-like forms are numerous. Spores are formed rery sparingly, and the blood serum is liquefied.

synthetir medin (Uschinsti!). - In Uschinsky's medium no growth occurs; but if the medium is neutralized, good growth ensues. The bacilli orcur in threads and a pellicle is formed.

Dunham's solution.-The bacilli are small when grown in this solution. No threads torm, but there is a slight indol reaction after nine day's growth.

Relation to free orygen.-Cherne states that the germs grow most rapinly on the surface of agar and arrange themselves side by side; and they prodnce spores in this position atter a few dars' growth. Eisenberw (Bakteriologische Diagnostik, Hamburg. 1891, p. 298) says nothing under the head of aerobiosis. IIoward (Foul Brood: Its Natural IIistory and Rational Treatment. Chicago. 1S9) t) writes that, "It grows best under anaerobic conditions: is a facultative aerobe; grows under the mica plate, and in the presence of oxrgen the growth is slight and slow." Iow and also states that under anaerobic conditions it emits a foul odor resembling that of foul brood. It will be thus seen that Cheyne and Ioward do not agree on this point. The formel anthor also sars that the chatracteristic olor is given off under aerobic conditions, whilst lloward stites that this smell is emitted under anaerobic conditions. Further. Cherne states that the barilli grow with great rapidity on the surface of agir. whereas IIoward obtains his best growth under the mica plate, which does not give complete analobiosis. IIoward's conclusions are thus at viance with Cherme's, and my own results fully corroborate those of the latter anthor.

Howard states that the ritality of the spores of $B$. alrci is destroyed when exposed to atmospheric air from twenty-fomr to thirty-six hours. In making his experiments he took sterilized road dnst and mixed it with the dry fonlhrood masses from several cells, which were previously dissolved in distilled water. The mixture was worked dry and spread on sheets of paper, and trial cultures were made immediately and at intervals of erery twelve hours for three dars: and, arecording to his results, no growth oecurred after thirty-six lownr.s. In giring these results. Howard does not state whether he exposed the spores to smulight or diffused light: nor does he mention the age of the dry foulbrood masses, which he used from sereral cells. These are points of considerable 


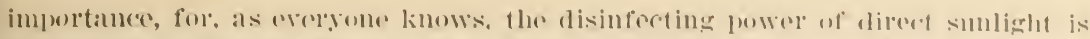
much greater than difrised light. and the vitality of the spoles fom foul frome

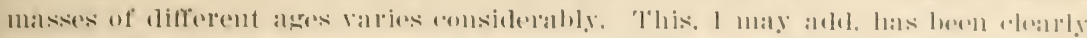

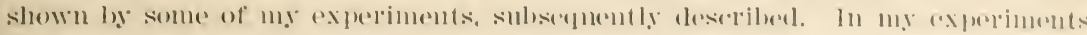

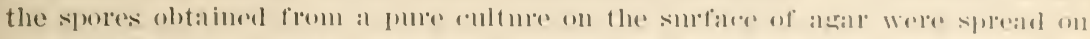

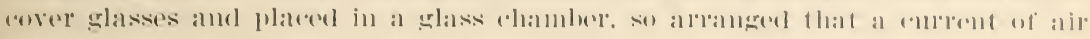

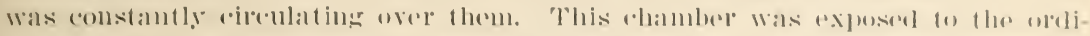

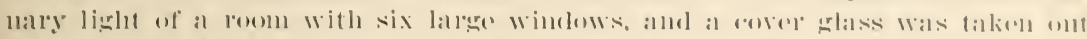

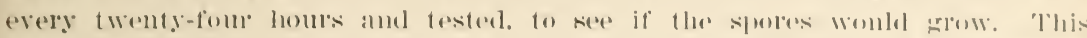

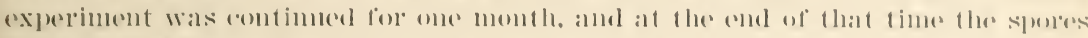

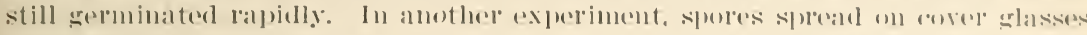

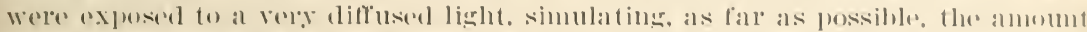

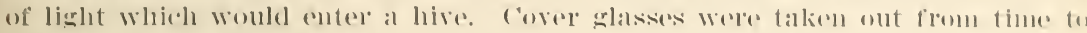

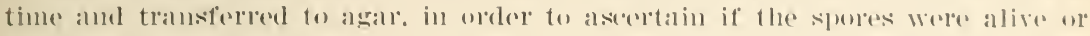
not. The experiment was begm two years ame four months ago, and from the

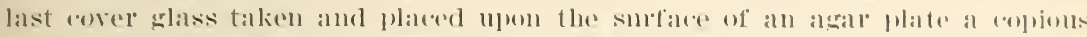
and typieal growth of l3. aleri was obtatined. Further. thin strips of tilter palper, plunged into a bouillon culture and allowed to dry, were threalded on a

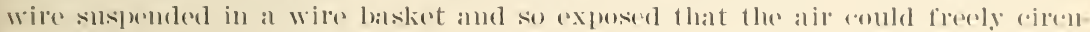
late alound them in the molinary light of a room. Triall eultures weer matle at intervals, and at the expiration of six months the spores from the paper serminated when strips were platerl on the surface of agar.

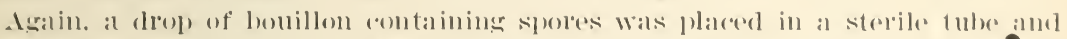
allowed to e? : and at the expiration of one hundred and twenty-four homrs (thirtg-six of which were in sunlight at a temperature valying from :30 to $37^{\circ}$ C. sterile boullom was adderl. The tubes were then placed in the incubattor. and in less than twenty-fom hom's a good srowth of the germs had taken platere

From these experiments it will he seen that the results are direrety at valrame with Howard's statement, as they go to show that the vitality of the spores of $\mathrm{B}$. alrei is not destroyed ly exposure to atmosplerie alr. with or without sunlight. for even a much longer time than twenty-four to thirty-six hours.

With regard to the aerobiosis of this bacillus, good growth has heen obtaned in an atmosphere of hydrogen ly Nory's method. Buchuer's method also salve good results. The growths in the various media are very similar to these produrerl under aerobic conditions, but with this difference, that the surface growths are, as a rule, whiter in the hydrogen atmosphere. In illuminating gats

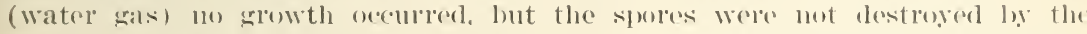
action of the gals; for when the gas was let ont of the Nory jalr, Eeed growth

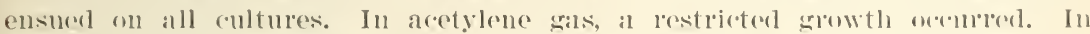
fermentation tubes growth orecurred both in the open and in the elosed alm of the tubes. No gals was formed, the bonillon in the elosed arm was miformly turbicl. 'Thus B. alrei is a falcultative analobe.

Profluctirs" of alliali.-In ordinary houllom a slight amount of ammonia is formed. Control boullom diel not give the Nessler test. In whererine and the sugar houillons, there is no trace of ammonia. ('heymes enlumes are falloty alkaline. both before and after inoculation in meat infusion. Klamann stafes that ammonia is produced.

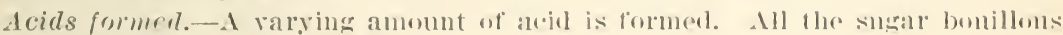
give an acicl reartion.

Formation of pigment. -On potatoes a pellowish glowth is prodnced; on all other media, the surface growth is white.

Development of odors.-Cherue states that quatine rultures grive off an 
olor of stale, but not ammoniacal urine, or what may be better described as a shrimpy sulell; and this peruliar odtor has been found by Cheshire to be distinctive of diseased larvie. Klamamn and Howard both state that a peculiar odor resembling that of the diseased larve may be noticed in artificial cultures.

The effects of desiccation.-I have already noticed, under the head of "Relation to free oxygen," that the spores of $B$. alvei hatre considerable vitality in withstaneling desication. My experiments prove conclusively that the spores ale extremely hatrel to kill hy desiccation and in this respect resemble those of anthrax, which are known to resist thorough desication for a number of rears. one experiment which showed this characteristic was as follows: An agar plate completely covered with a trpical growth of $\mathrm{B}$. alrei was allowed to dry out completely, and was left exposed to the ordinary light of the room for seren months, and at the end of that time, a portion of the film was scraped off with a knife. plated on suitable medium and incubated, with the result that a typical growth immediately ensued.

Spores on cover glasses were exposed to September sunlight (latitude $43^{\circ}$ ) for varying periods of time, and growth occurred after four, six, and seven hour's exposure. The age of the spores raried from five days to eighteen months; and spores three months old were not killed by seren hours" exposure.

From the symptoms given in this paper the disease with which Professor Harrison worked was doubtless Anerican foul brood. From the discussion of geographical distribution this is also evident, for he says: "I have examined diseased larve from Canada, from Europe, *** Cuba, and thirteen States of the Union. ranging from New rork to California and from Michigan to Florida." American foul brood is thus widely distributed. but from all these specimens Professor Harrison obtained a bacillus which he called Bacillus alvei. Since we now know that Bacillus atrei is found in European foul brood and not in American foul brood, it is evident enough that the germ must have been another bacillus. European foul brood, as far as the author is able to learn. is not found in Canada nor Cuba, and, although now found in several states in the northeastern United States and spreading, is not, as Professor Harrison would have us believe, widely distributed in the United States.

How can this be accounted for? The only way open seems to be in the identification of the bacillus. I do not feel qualified to pass judgment on the accuracy of the description of Professor Harrison, but the matter has been referred to Doctor White, and he assures me that the description just quoted fits the bacillus which is described as Burithus 1 as well as it does Bacillus alvei. If this is true, we can only conclude that Professor Harrison, not knowing of the existence of two diseases, made a serious error in his identification. In no place does he speak of any difficulty in obtaining enltures from American foul brood. For comparison, Doctor White's Iexcription of Bucillus a 1 (possibly B. mesentericus) is here quoted. 


\section{Discilli: i.}

\section{(B. mesutericus?)}

Oecurrence, Found rery frecpuently on combs, on seraphings from hives, and on the bodies of bees, both diseased and healthy.

Ciclutin colonics,-Verg young colonies slow irregular edges, but very soon liquefaction takes place and the colony gives rise to a rireular liepuefled areal, covered witli a graly membrame, which later tums brown.

Agor colonies.-Sulerticial colonies plesent a very irregular margin ronsisting of outgrowths taling place in curves. Deep colonies show a filamentous growth having a moss-like appealrance.

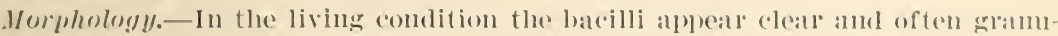
lar, arranged singly, in pairs, and in chaniss. 'l'he flagella are distributed over the body. The rods measure from $3 \mu$ to $4 \mu$ in length, and from $0.9 \mu$ to $1.2 \mu$ in thickness.

Motility.-The bateilli are only moderately motile.

sipores.-sipores are formed in the midllle of the rod.

Grom's stuin.-The balcilli take Gram's stalin.

Orlygen requirements.- Aërobic and facultatively anaërobie.

Boullon.-Iuxuriant growth in 24 hours, with cloudiness of medium ; a gray floceulent membrane is present. Later, the membrane sinks and the medimm cleal's, leaving a heary, white, floceulent sediment, with a growth of the organisms adhering to the glass at the surface of the medium. Ireaction allatine.

Glucose.-Luxuriant growth takes place in the bulb, with a moderate, floc(nlent growtl in closed arm. The gradual settling of the organisms canses a heary white sediment to form in the bend of the tube. The reation is at first slightly acid, but subsequently becomes alkaline. No gas is formed.

Lactosc.-Reaction alkaline.

succhorose.-Reaction alkaline.

Lerulose.-Reaction acid.

Multose.-Reaction acid.

Mannite.-Reatction alkaline.

Pototo water.-Reaction alkaline.

Agor slant.-A luxuriant growth takes place on this medium. The growth gradually increases to a moist, glistening one, being then friable and of a grayisil lyown color:

sermm.-A luxuriant, brownish, glistening, friable growth slueads over the entire surface. No liquefaction is olserverl.

Pototo.-An abundant fleshy growth of a brown color spreads orer the entire surface. The water supports a leary growth. The potato is slightly discolored.

Milk,-I'recipitation takes place rapidly, followed by a gratual digestion of the casein, the medium changing from the top downward to a translurent liduicl, becoming at last semitransparent and viscid.

Litmus milk.-Precipitation of the assein takes platce usually within 24 hours, follower by a gradual peptonization. Reduction of the litmms ocents ralpidly, leaving the medium slightly hown: later the bhe color will retnon on exposing the milk to the air by slaking. Reaction alkiline.

Gelatin.-In almulant growth takes place with rapid, infundibnliform lirpnefaction. A heary, white, friable membrane is formerl on the surface of the liquefied medium. A flocrulent sediment lies at the bottom of the clear liquefied portion.

Acid agor.-Growth takes place.

Indol.--None has been olsserved.

vitrote.-Reduction to nitrite is positive. 
Dr: Willian R. Ioward, of Fort Worth University, Fort Worth, Tex. has publisherl sereral papers on the bacteriology of bee diseases. In a paper published in 1894 (Tork Publishing Company, (hicago) he attributed " foul brood " to Barillus alvei. Eridently he was dealing with American foul brood, and we now know that Bacitlus farea is present in that disease.

The same author molertook to determine the cause of pickle broorl and described a specific fungus, Aspergitlus pollinis. No investigatol has since been able to find any such fungus in simila. specimens.

In 1900 (Gleanings in Bee Culture, p. 121) this author published an account of some brief and entirely inadequate investigations made on what he chose to call "New York Bee Disease. or Black Brood." I specific organism. Bacillus mitii, is described, but the view is expressed that this is modified, perhaps. by Bacillus thoracis. During the investigations of the Department of Agriculture it has been learned from whom Doctor Howard got his specimens, and the same men have furnished specimens which they declare to be of the same diseased condition as those furnished Doctor Howard. These, however, contain Bacillus alrei, and the disease is the same as that described by Cheyne, now named European foul brood.

It is most unfortunate for Doctor Howard that in not a single point have his descriptions been verified. Certainly it would seem unwise in him to put out the names Bacillus milii and Bacillus thoracis as new species without descriptions and after so short an investigation. We can not, therefore, sympathize rery much with him when his views are overthrown.

The American bee journals and text-books on apiculture have until recently contained statements to the effect that Bucillus alre: is the cause of the disease which has been almost universally called " foul brood." This is due not only to the publications of Mackenzie, Harricon. and Howard. but very largely also to the attempt to determine Bucillus aleei by microscopic examination. The best-known case of this is probably the examination of diseased brood made by Mr. Thomas Wrilliam Cowan, editor of the British Bee Jommal. On a visit to Medina, Ohio, Mr. Cowan was shown a sample of diseased brood, and after a microscopic examination he announced that he found Bacithes aleci, and that the diseased condition is identical with that found in England. That this ropy type (for such it was) is found in England can not be doubted, but that the germs which Mr. Cowan saw were Barillus aleci may well be doubted. I have taken particular pains to ask Mr. E. R. Root, who was present. whether Mr: Cowan made a cultural examination, and was assured that the microscopic examination was the only one made.

The announcement of this examination in Gleanings in Bee Cul- 
ture and the A B ('of Bee ('ulture, rompled with the exrellent reputation of Mla. (owan, made this appear convinding to Anerican bee keepers. It must be remembered, howerere that at that time no one had questioned the presence of lincillns alei in American font brood and on finding bacilli the and hesion that they were bareilles aleei was natural, erom thongh erroneons.

Mr. Edwand Bertrand, in his book " ('onduite dn lincher," makes a similar amomomenent, stating that he and Mre. (owan examined brood described as ropy and fonnd barillus alderio

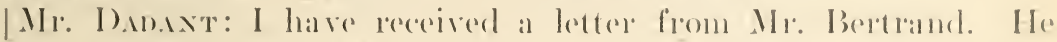
informs me that they (Mr. (owan and himself) had examined foml brood. but I know from the tone of the letter that no cultures were made. |

To indieate how much reliance may be placed in micreseopic examinations in the absence of cultural tests, let me quote from stembergr's Text-book of Bacteriology, 1901 edition, pages 13 and 14. It shonld he borne in mind that this refer's to all microscopic examinations of bacteria and not specifically to bee diseases.

The barteria ale also elassified aceording to their biological character's, and it will be neressilry to consider the virious modes of gromping them from different groints of view other than that which relates to their form. 'l'his is the more important, inasmole as we are not able to differentiate species ly morphologinal rharacters alone. Thus, for example, there are among the spheriabl haterial, or microcorei, mmerous well-established speries which the most expert microscopist could not differentiate by the use of the microseope alone; the same is true of the rod-shaperl bateria. The assmuntion often male hy investigator's who are not sufficiently impressed with this fact, that two micro-organisms from different somrees, or even from the same soure, are the same beramse stained preparations examined under the microseope look alike, has lod to serions errors and to inucle confusion. As an example of what is meant, we may refer to the? lus organisus. Before the introduction of Koch's "plate methed " microcoeci hand heen observed in the pus of arote abserses. Some of these were gromped in chatins-streptorocei-and some were single, or in pairs, or in gromps of four; but whether these were simply different modes of sromping in a single species, or whether the chain mirococei represented a distinct speries. was not determined with certininty. That there were in fact four or nore distinet spereses to be

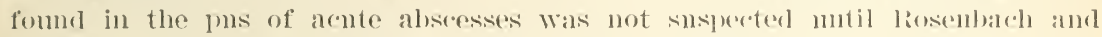
I'asset demonstrated that this is the case, and slowed that mot only is the

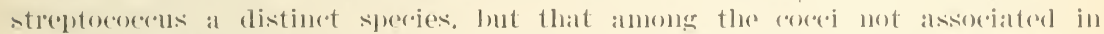
chains there are three species which are to be distingnished form each other by their ablor when grown on the surface of a solid ronture merlimm. Oile of these lass a milk-white color, one is of a lemon-yellow eolor, while the third is a golden-yellow:

This brings us down to the work of Doctor White. His investigations were begun with Dr. Y. A. Moore in 1902.2 and in Jamuary, 1903. a preliminary report was published. During the first year specimens of "black brood " were examined and to the surprise of the investigators Bacillus aleci was found in every case. Obvionsly. 
then, they were working with the foul brood of Cheshire and Cherne (European foul brood). In a second short paper by Doctor White a brief note is given concerning some work done on the "ropy type" of foul brood. He recognized that he was dealing with a disease the wane of which had not been decribed and the disease is called for the time " I brood" and the bacillus, Barillus $X$. The final results of the investigation appear in Technical Series. No. 14, Burean of Entomology, under the title "The Bacteria of the Apiary, with special Reference to Bee Diseases." Doctor White's description of Bacillus larea is as follows:

\section{BACHLACS IARYA.}

()remence-Constantly present in diseased brood from colonies affected with American foul brood.

Gelatin.-There is no growth.

Iorphology.-It is a slender rod, having a tendency to form in chains. This is especially true when grown in hee-larvie boullon.

llotility.--The bacillus is rather sluggishly motile.

spores.-Spore formation takes place. This can be observed best in the different stages of the disease and decay of the larve.

Orygen requirements. - When Liborius's method is used, the best growth usually aplears near tr but not on the surface. After a few generations a surface growth may be obtained.

Bonillon.-There is no growth.

Glucose bouillon.-There is no growth.

Lactose.- There is no growth.

saccharose.-There is no growth.

Agar plate.- There is no growth.

Bec-larre agar.-The inoculations must be made with the medium liquefied. The growth takes place near to but rarely on the surface. Cultures must pass througl a few generations hefore a satisfactory surface growth can be secured.

Bec-larter agar slant.- On the surface of this medium a thin. gray, nonviscial growth tikes place.

Glucose agar:- Sliglit growth has been observed in the medium. No gas is modinced.

I'otato.-There is no growth.

Milk:-There is no growth.

Litmus mill:- - There is no growth.

frementation.-In hee-larve bouillon no gas is produced.

Indol.- There is no growth in sugar-free bouillon.

To summarize, then, Bacillus aleci is found universally in European foul brood; Bacillus larere in American foul brood. No specific micro-organisms have been found for the so-called pickle brood or paralysis. Knowledge of the two wort brood diceases is accurate chough to enable us to combat them by applying principles acquired hy comparison with results of work with other micro-organisms.

That our knowledge is complete is far from true. Not only is there much to be learned which is of purely scientific interest, but points of the highest practical importance are yet undetermined. 
[Note.-Sereral other papers of importance have been issued on this subject which were not discussed at the Inspectors meeting. They, howerer, have an important bearing on this smbjece. Lannbotte

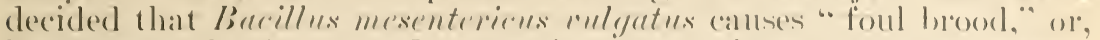
in other words, that Buceillus aleci is but a variety of Burillus mesenterions. His work, howerer, is far from convincing. The principal point of interest in this regand is that he harl great difficulty in getting a growth from the ropy type of foul brood (Amediean foul brood) on orelinary media. Burre in 1!)(0) published an acrount of his work and fomd Bacillus alvei in a few specimens fom switzreland (indicating that European foul brood is found there). lunt found another organism which grows with difliculty: the latter is molescribed and mmamed, and it is possible and probable that he worked with Barillus Tarere White. Nasissen (1906) found the same difliculty, isolating Bacillus alrei in only 13) specimens of diseased brood out of 112 received. He, too, found an organism which conld be made to grow on ordinary media only with difficulty and called by him Bacillus lramdenturgiensis. It is undescribed, so far as is known to the writer. He also claims to have found another organiom, s'pirocherte apis Maassen, but has not established any causal relationship.

These papers all tend to confirm the work of I'octor White. BurilTus at ece is not found in the ordinary ropy type of " foml brood," but another organism is; this is probably the Buacillus Tarere of I Doctor White.

In the face of all these facts several prominent bee men of England are attempting to discredit all this work, the eriticism, so far as is known to the writer being based entirely on comparisons of literature and on an entire lack of investigation. They have. further. misread the papers issued by the Department of A griculture on this subject. It seems entirely innecessary, therefore, to review the criticism in detail.-E. F. P.]

EXISTENCE OF BOTIF AMERICAN FOEL, BROOD ANI EUROPEAN FOUT, BROOI) IN THESAME ('OLONY.

Mr. Atrinter. Do you think that both diseases, American foul brood and European foul brood, could exist in the same colony?

Doctor Pundurs. Reports are sometimes receired that a colony is infected with both diseases at the same time. but this is contrary to the experience of those persons most conversant with these conditions. While it may be possible for a colony to have the infection of both diseases at the same time. it is not by any means the rule, and such cases are probably not anthentically reported.

Both diseases are found in New York State. The inspectors have to treat both diseases and they treat both in the same way. but they have never found both diseases in the same colony.

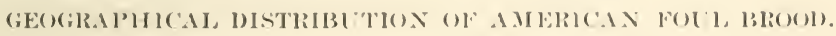

Mr. Dabant. Is not the Ameriean foul hrood spread more oree the world?

Doctor Philuips. It would seem so from the literature. It is found in almost every State of the Union, while European foul brood 
is, as far as is known. fomm only in the States mentioned a while back.

Mr. D.m.st. 'The Anerican foul brood is characterized by the ropy condition. 'The Ferench name for their common brood disease is " loqne," meaning tatters, and this name therefore refers to what we (all Ameriean foul brood.

Mr. Cogishom. Which of these diseases is the one found in Cuba!

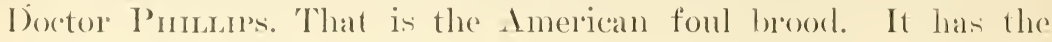
lypical ropy character.

EFEECT OF CILANTE ON VIRTLENCE.

Mr. L. F. Juxead (Colorado). I would like to ask if brood diseases are equally bad in all States or has climate anything to do with the virulence of the diseases?

Doctor Prifurrs. Climate undoubtedly makes a great difference. The American foul brood of California is not anythirg like the same disease in the East. It is simply terrible in California. Mr. Rankin will tell us about that later in the day. It is the same disease. but its ravages are much worse.

Mr. Juxent. Mr. 'T. L. Thompson (Colorado) sent some pickle brood to Dr. IT. R. Howard, and the latter called it "black brool." but said: "In your State it will not be so bad."

Doctor Prinlips. It was probably not European foul brood. That disease has not been found west of the Mississippi River.

\section{ASSOCLATION OF INSPECTORS OF APIARIES.}

It was decided that it would be well for the inspectors of apiaries of the various states to be oreanized in some way to bring about ereater cooperation in the work. After discusing the question it was finally decided that Mr. N. E. France. inspector of apiaries for Wrisconsin. shomld act as chairman of a committee on organization and appoint his own associates.

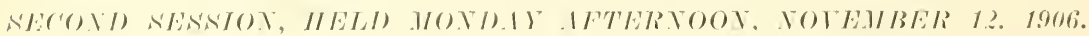

Doctor P'nintips. In the morning session we covered rather tholonghly the scientific side of investigations on bee diseases. That is, of comre, important; but when it comes to the practieal work on bee discase there are two subjects of much greater importance, namely, methods of treatment and legislation. We will first discuss the treatment of these two brood diseases and then take up the disenssion, in so far as we can, of the laws now existing, with sleggestions as to the form which a law should have to give the best lessults and the powers which should be given to the inspertors under the varions conditions which mal arice. I have, howerer, a paper that I wish to read first, 
which was written hy Mr. C'harles Stewart, of Áammoms ille. X. I'. one of the inspectors of that state. I had the pleamente and privilene of spending fomr weeks in the field with Mr. Stewart last spring, and I feed that I can saly that if there alle any goost inspertors in the Inited states one of them is Mr. Charles stewart. Mr. Stewart is exceedingly sorry that he can not be here, and he recplested me to reat this paper to yon.

\section{APIARY INSPECTION IN NEW YORK STATE.}

lig ('HLS. NTEWART,

Inspertor: Third Mistrirl.

Brotula Ixspectoms: It is with a feeling of regret that I write this paper. knowing that it will be imposible for me to le with you at what must be both a pleasant and profita!ble meeting.

It is hardly necessary for me to describe European foul hrood mon to refer to its entrance into New York state, except to say that it was bronght in some years ago by a shipment of bees from one of the Southern states, and just as we were feeling that wo had noarly stamper it ont and were master's of the situation we diseovered that at least one if not two fresh importations had been made in a section of the State where no trouble of this kind formerly existed.

I wish to call your attention to the fact that no bee keepere can ferel reasonably safe from infection nutil every state in the Union is muder the surveillance of a keen-eyed inspector who knows every spot of clisease in his jurisdiction and allows no bees to be shippeed ont of such territory. Had the inspectors of New York State not adopterl this rule, disease would have spread not only all over our state. but to far distant points. as many, fearing the loss of their appiaries, were eager to sell at a sacrifice. In order not to make this mule a hamelship to om people, we have made it a practice to find a buyer within the

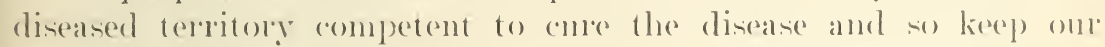
tronbles within om own family.

I wish I had the power to paint to you in words the pathetio picture when four good men and true, who had been bes liecpere from boyhood and had large interests to protect. took up this work. I have seen the faces of strong men blanch with fear or turn erimon with angere at the first visit of an inspertore, and latere, when their bees were saved and their product narketed, the yommen mant sent back to college, their little children aned for. or perthape the home sared. these same men with tears on their cheek would give one a hand elatep that was far more olognent than words and posiceseres a value beyond grold. I question if there is an inspertor present to-day who from a mere money point of view would not be better off' if he had given 
his entire time to his own business; ret I honor this American spirit you possess in that, having once started out to accomplish results, you refuse to turn back until the end is attained.

I hardly feel like posing as an instructor to this gathering of inspectors, but will call your attention to a few important points. A question often asked is, " How does the disease spread so rapidly?" I would answer, " By means of infected honey." No field bee from an infected colony goes ont with its honey sack so empty of honey that it contains no germs. and on their return many bees mistake their hive and carry disease to their near neighbors in the same apiary, so that it is a common thing to find a badly infected colony and those in the same row infected in proportion to their distance from the source of contagion.

How the disease spread from yard to yard when no robbing took place was for a long time a puzzling question, until I found an apiary of black bees 3 miles from an apiary of golden Italians that were infected. In many colonies of the yard of blacks could be found a sprinkling of the golden Italians and in nearly every case these colonies showed traces of disease. Evidently bees are often driven by stress of weather or some other cause to seek shelter far from home, and thus disease may be spread.

The have found no bees immune from disease, yet some rigorous strains of Italians are nearly so. For years we have recommended the introduction of young Italian queens, but have warned the owner of an infected apiary not to depend on that alone, as it would prove disastrous in localities where the disease has just made its appearanee and the bees are mostly black. This method will often prove rery successful where European foul brood has existed for some time and lost much of its virulence, but, like the use of drugs, it is not a safe method for the inspector to adrocate, while the shaking method has never failed us if done in a thorough manner. Colonies that are found to be diseased late in the season may be cured by taking a way all their combs after brood rearing has ceased and giring them clean combs from a healthy colony, as any dicease germs that are contained in the honey sack will have been eliminated long before brood rearing commences in the spring.

In conclusion I would say that to be successful as an inspector a man should not only be well rersed in the management of bees and hee diseases, but he must be broad minded, even tempered, possess al liberal amount of tact and diplomacy. and be a shrewd judge of human nature. Yes, and eren more, he should be able to win the confidence of other's and share their burdens, and when the time draws nigh when the working tools of life shall drop from his nerveless clasp he may look back with satisfaction to a life well spent in the service of other's. 


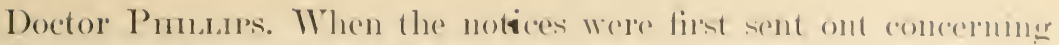

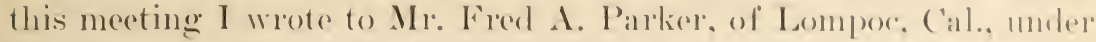

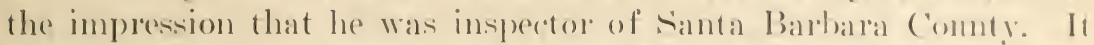
secms that he has resigned and santa Barlonla ('ommty now has no inspector. Ite has, however, sent a paper. which will now he reals:

\section{AMERICAN FOUL BROOD ON THE PACIFIC COAST.}

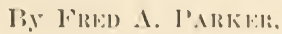

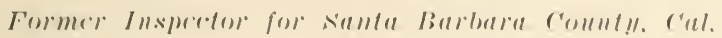

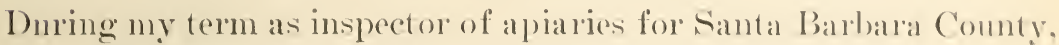
cal., in the year 1905, 4,073) colonies of bees were inspereder. I discovered ti cases of American foml brood and fommel 170 rolonies not on movable frames. 'These were ordered transforerl, and in somo inst:mees I did the work myself. Every ase of fonl brool was either burned or treated by the shaking method. Five were burned. being too weak in nmmbers to treat. Preparatory to burning. I womle dig a hole about 2 feet deep and build a fire in it. then throw in the frames containing the diseased brood. After the fire did its work the hole was filled with dirt to prevent bees from getting diseased honey, if any might have been left unconsumed. If any comb was attached to the hives the latter were placed on the fire in the hole and when the interior was a mass of flames they were removed with a shovel, hoe, or other long-handled tool and water thrown on to extinguish the flames if the wood had caught fire. The bees were shaken into an empty hive and allowed to build somb on the lid for three days, when they were shaken onto frames with starters and allowed to proceed. 'The comb was scraped from the lid and the lid scorched. This treatment, if carefully performed, is surecesifful in about nine-tenths of the cases treated. Bee keepers alre generally too careless in handling the diseased combs, thes giving other loses an epportmity to steal a load of infected honey.

I have read many statements to the effect that queens do not carry the infection, hut my experience has convinced me of herwise. I had haken six diseased colonies in my own aplary in lon) a and fonl were completely cured. While I was equally caleful in handling these cases the discase reappeared in two of them. I shook thom again, and again in due time the discase appeared. 'This cansed mo' to suspect that the queens wele defective, and to test it I exchanged them with the queens of two perfoctly healthy colonies, shaking the diseased stock asain. In both cases the come was complete, while the lisease appeared in the brood of the formerly healthy colonies. 'This appears to me to demonstrate beyond dombt that tho oraries of preens are occasionally infected, that their coges transmit the germs of Ameri(an foul brood, and that the disease will develop' in any colony to 
which they are introduced. If this occurs in one-third of the cases or one-tenth. it will pay to requeen in every case, unless you have an especially valuable queen you want to save, in which case it may pay to experiment. For that reason I now practice requeening every colony treated for American foul brood.

My experience with drugs lias been unsatisfactory in every case. I lave tried carbolic, rosemary. Bingham's sulphur plan (as outlined in (ileanings in Bee Culture, A pril 15), 1902), the formaldehyde spray plan (Cleanings in Bee Culture. December 1,1!03). and naphthol, but while all these drugs have the effect of checking the disease and preventing its spread orer the combs as long as used, none of them cures it, regardless of the duration or persistence of its application.

I have not tried the formalin-gas plan, nor do I intend to try it, or any other drug treatment, so long as the shaking treatment will cure. While destruction of frames and combs is expensive, it is to my mind cheaper in the end than experimenting with every new cure that is exploited in the bee journals. After trying these you are forced to resort to the shaking treatment to make the cure complete, so why not use it at first and sare the trouble and expense? So long as honey contains spores. so long will drugs fail, because they can not reach and destroy the spores. Even if a temporary cure could be effected the disease would reappear when the bees began feeding the larva this germ-laden honey. Nothing short of remoring all the comb. will make the cure permanent.

As an apiarist I have had experience in many infected apiaries. and in every yard where the disease has ever been, with one exception, a few cases develop every season, and will continue to do so until these old combs are retired. If a whole apiary is to be treated, it pays to save the wax and honey, but I do not believe in bothering with them if only a few hives are to be treated: it does not pay to take the trouble. Of course progress is desirable, and I would not discourage anyone who wants to experiment with drug treatments, but I believe if any good is ever derived therefrom. it will come from the work of experiment stations or trained scientists, who have the means and time to devote to it and do not have to depend on apiculture for a living.

Anerican foul brood seens to act differently here than in most places. The question may arise, Is it American foul brood? It has the smlien, perforated cappings and the foul, glue-like odor. and it ropes from one-eighth to several inches. I have seen many cases where the brood chamber was badly atfected with foul brood. but when a honey flow came, the queen moved up and not one cell of disease appeared. I have known these bees to cast strong swarms. which proved to be entirely healthy.

Igain. I have known American foul brood to disappear without 
any treatment whatever. Mr. B. Dickens, one of the most intelligent and observing apjarists, had marked a colony for treatment. Not beinen able to attend to it for several weeks. he was surpurised when he diel open it to find every trace of the divease gone. I hat the same expe

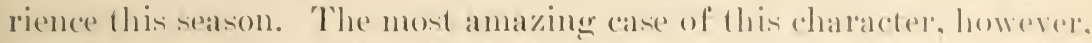
was the experience of Mr. W. J. ()ates (now my husinese partmer) in 1903. He purchased an apiary of 30 colonies, neanly every colony being badly affected with foul brood. 'The former owner, Mr. I. II.

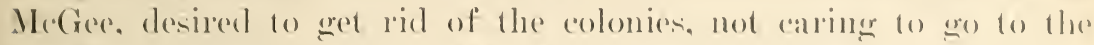
trouble of shaking them. Mr. Oates treated the whole apialy by the shaking treatment. As soon as there was sealed brood in the hives. it was seen that disease had dereloped in about three-fourths of them. I examined these colonies myself, and if they did not have the disease after the shaking, then I never saw a case of American fonl brook. Mr. Oates did nothing more to them, and, becoming disgusted with the proposition, he sold out to Mr. F. S. Moorehead and went to Nevada. 'The year $190+$ was a poor season here and honey was extracted from these hives once, I think. Nothing was done for the disease. In 190.) I inspected these bees, expecting to find them recking with disease, but to my surporise I coukd not find a single rase of foul brood; it had completely disappeared. Mr. Oates was surprised when informed of this, but he managed this apiary that season on the shares. and no disease developed. I had occasion to look through this apiary just last week, and not one case of discase exists there to-day. That is a case I can not understand. mlesin it is that by the shaking the bees were relieved of all diseased honey, and, being shaken in the fall, the queens ceased laying entirely later. and the bees cleaned out all infection. But I am mable to account for the wholesale reappearance of the disease, muless the treatment was carried out in a careless mamer. I am rertain that the circumstances occurred just as related. The simmins plan is not a drug plan, and I intend to test it next season, if I find any American foul brood.

Sometimes disease spreads quite rapidly here. infecting one-lalf or more of the colonies in two seasons. Then l kuow of some appiaries where a few cases have existed for years without any pereptible increase. I know of one instance where an aplary was entirely dentroyed by the disease in one seasom. Whether ont climatice conditions have anything to do with the matter I do not know, but it is a fact that foul brood as it exists here is of a very erratic nature. Furthernore, it is dangerous, and a relentless war should be waged against it mutil it is exterminated.

A paper entitled ". The appointment of inspectors." by Fred A. Parker, of California, was then read, in which the writer showed 
that the work of the inspector is far from easy. Many bee keepers criticize the work of the inspector as soon as their apiaries are examined. and fault is found with inspection and the inspectors. It is the duty of the bee keeper to mphold the inspector as long as lie is doing hone-t work for the bee-keeping industry. The salary paid an inspector is in most cases smaller than the income he could malke by remaining at home and doing the required work in his own apiary. so that inspection is usually done at a financial loss to the inspector.

Mr. J. M. Roxkix (California). It has been my privilege since May. 190.), to be in touch with bee-disease work on the P'acific coast. During this time I have visited many diseased apiaries throughout the State of California.

Few eastern people have an adequate conception of the bee-keeping industry in California. It is not an uncommon thing for one man to own 4.000 colonies of bees. This. of course, puts the business on an cntirely different footing than in the East. In the same way, conditions of disease are also different. The control of American foul hrood among so many colonies becomes a much more difficult proposition than it is where the bee keeper owns only fifty to seventy-five colonies. There seems to be no doubt, also, that the American foul brood is much more virulent in California than in the East. Whether this is due to some climatic condition or not, I do not know. I have seen an apiary showing only slight infection in February become almost a total wreck in August. In California, also, the bees fly nearly 300 out of the 365 days in the year. and the honey flow in most parts of the state is of comparatively short duration. This makes conditions farorable for more rapid infection than in colder climates where the bees are confined to their hives during about half of the rear.

Under such conditions you can readily see that treating the disease is diffienlt. It must be done at exactly the right time and under farorable conditions or the treatment is worse than u-eless. Sone of the best inspector's in California use the shaking treatment. and all of them shake twice, as well as disinfect the contaminated hives. There are some few men who do not believe in treating by this method and who burn all diseased colonies, only saving hives when these are in good condition. In counties where bees can be bought for .50 cents a swarm it may not be a bad plan to destroy all direared colonies, as this is certainly an effective treatment if the burning is complete.

I treatment very farorably thought of by some is that of thoroughly boiling all diseased material. $\Lambda$ large tank is used and the diseased colonies, after having been sulphnred the night before, are carried to the tank and all the combs thrown in. After all the wax is melted. the frames are removed from the tank and placed on the fire uncler the tank as fuel. This is certainly an effective way of eracli- 
ating the disease and can be recommended more highly than the burning plan, as by this means the wax is not destroyed.

California has the comnty system of inspection, and probably the smallest number of colonies which one inspector has to look aftere is 30.000 . From that number the colonies rum up to $1.00,000$ in a single cominty.

Doctor Puntaps. What Mr. Rankin has just said is in line with my own observation during the middle of the smmmer. I risited one apiary in Ventura Comnty, with Mr. A. G. Edmondion, the inspedor for that county, and he showed me lis hives. Two years ago this apiary was in the hands of a competent bee keeper and no disease was present. Ventura County is so large that the inspector can cover only one half in one year and the other half the next yeare When we examined the apiary we found 15 healthy colonies and 13,8 hives in which the bees were dead or nearly so.

TREATMENT FOR BEF DISLASES.

In discussing the methods of treatment, it would be a good plan to call on each of the inspectors present and get earch one to tell what method he employs. Te should hear first from Mr. X. E. France, inspector from Wisconsin. He is the oldest inspector in the Inited states in point of service.

Mr. Fraxce. Referring to the paper which was just read, I have tried some of the methods of using drugs in the apiaries of competent bee keepers and invariably all these methods are failures in Wrisconsin. The fumigating with formalin seemed for a time to check the disease, as did also some of the other drugs, but in the end they all are failures. The one method that has given universal satisfaction we owe to the oldest inspector in America, Mr. William McEroy, of Ontario, and it has often been termed the " MeEroy method." The plan is to remore the bees from the infection and keep them away" long enough to use up whatever infected honey there is in the stomach of the bee.

I am not satisfied to stop with finding disease in a yard and immediately prescribing treatment. In fact, I seldom, after looking orer the yard and finding the disease, begin to prescribe treatment. for' I foel that we are not yet ready for it. What is the use of treating when some neighbors might have diseased colonies? Take a wide circuit; then treat at once all colonies having disease. This has sometimes rexed the bee keepers, for they want me to stay and show them what to do at once, but I tell them that I see no good in treating colonies while leaving another source of infection.

I try first to instruct the owner of the bees to be careful in his management. If, in my julgment. he is one who keeps the apiary clean, 
and if I can depend upon him, I sit down and go over the "McEvor" plan with him very carefully asking him from time to time if he monderstands it. If he says that he does. I say: "Now. I am your" student; tell me what to do. When you can tell me what you are going to do, I will trust it to you." In nearly all such cases they have treated it without my assistance, and cured it. I can not recommend anything better than the "McEroy" plan.

Doctor Prinlips. There is just one thing I should wi-h to add to that. The treatment of taking bees from the infected combs was originated in 1769 by Schirach, as nearly as I can find out, and if we are going back to give credit to the originator of this plan, Mr. McEroy is not the man to get that credit.

Mr. G. IY. Yonk (Illinois). Was not the plan original with Mr. MaEvoy?

Doctor Philusps. It was probably original with him, but it was adrocated long before in many European works.

Mr. Sumpr. The ground has been thoroughly corered by Mr. France. Two years ago Mr. France said to me: "Now, smith, I have tried almost everything, but I find the "McEvoy' plan the best. My adrice is to use the "McEvoy' treatment, as I have done." I have only had one case this year where I have had to make a recond transfer, and I found that to be due to infection from a neighbor"s colony that I did not get to treat the first time. but which subsequently was treated, and the bees were all right. I have no trouble. and I have great confidence in shaking. I don't alarm the bees. I shall give my method. In treating a diseased colony I use an extra hive. to which the bees are to be transferred, and an additional empty hive: in which I place the infected frames after the bees are shaken from them. The last mentioned is covered with a cloth to prevent other' bees from robbing. First I move the old infected hive back, and in its place put a clean hive containing clean frames. with strips of foundation. The frames are lifted from the old hive. shaken in front of the new hive, and then covered up in the third hive, which is used to store infected frames. This is all done in the middle of the lay. If there is no honey in the field, the colony should be fed well at night.

Mr. J. Q. Stoxe (Illinois). How do you treat the old hive?

Mr. Surtur. I either burn out the hive, paint it with kerosene oil and have it burned out, or wash it in strong salt water.

Mr. Freu Mrtir (Ohio). When you shake the bees, they carry orer honey, do they not?

Mr. Nantr. I set the hive right on the gromd. I do not jar the framee hard enough to jar out the honey.

Mr. Mrтн. You shake them off during the middle of the day. I it not better along toward evening? 


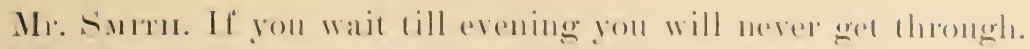

Mr. Mern. Do you use smolis in that operation?

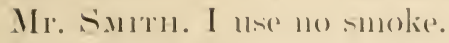

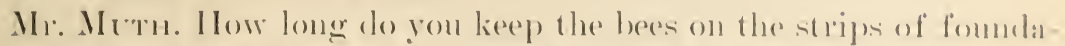
tion: do rom feed theme right atwa!?

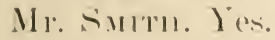

Mr. Muru. Уon dont believe in staring them at all?

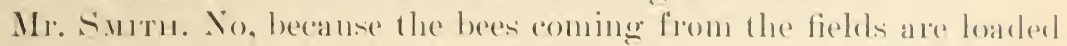
with honey.

Mr. Meтn. Do I melerstand that the bees have these harcteria all (1)er them?

Doctor P'mustes. Ves: they have the (ontamination on them. When they are shaken they of eomese have it all over thems and when they ane shaken off they doubthess take the bacteria with them.

The Metroysytem is the radical treatment of shaking wiec, which the majority of bee keeper's do not 11 se.

Mr. Yonk. If I mistake not, Mr. MeEvoy recommends the second sliaking.

Doctor PHulurs. He recommends the second shaking after the bees begin to drop from starvation.

(Duestion. What do yon do with the mulatched brood in the infected hive?

Mr. Nintru. My recommendation is to destroy the whole thing.

EFFECT OF REQLERNING ON JISEASK.

Mr. I).wnxw. Has removing the queens any value in treating the two diseases? Alexander, Simmins, and others have recommended lenoring the queens. Is this of any value in either disease?

Doctor Punluss. Is has been stated before to-elay. I spent font weeks last spring with the inspectors of New York state in the field. Both American foul hrood and European foul brood are found in that siate, but practically the same method of treatment is adrocated hy the inspectors for both diseases. Colonies found to be diseased a per - haken aceording to the method which has been described soreral limes in this meeting.

In order to save any healthy brood which is fommel in colonies inforted with disease, the sealed hrood from soveral colonies, forme to eight, is piles up in hive hodies above a weale colony which is diseased. In seven to ten days all the hood which is worth saving will have emereged and the weak colony will have been wangeel to one slong rnough to treat. This colong is then treated hy the shaking methorl as were the others. There is no neressity of wating more than ten days, for hrood which was nusealed when the hrood was first attacked will sararesly he fed sufliciently to emerege.

In addition to this treatnent, the inspectors recomment the in- 
troduction of young, vigorous Italian queens from good stock. It has been shown repeatedly that Italian bees are less liable to disease than most of the black bees, especially of degenerate stock, as is so much of the black stock when no attention is paid to improvement. In a pamphlet issued in 190:3 by the inspectors of New York the introduction of Italian brood was recommended. This is not adrocated as a cure, however, but merely as a means of protecting the colony against future infection.

Reference has been made to the introduction of Italian queens as a method of curing disease, and to this method the name of Mr. Alexander is attached. In the article in which $\mathrm{Mr}$. Alexander first ad vocated the plan he says, in part:

"Ilow to rid your apiary of black brood" (By E. W. Alexander).

This cure is on the line of introducing new blood into the apiary, * * *

Go to every diseased colony you have and build it up either by giving frames of maturing brood or uniting two or more until you have them fairly strong. After this, go over every one and remove the queen; then in nine days go orer them again, and be sure to destroy every maturing queen cell or virgin, if any have hatched. Then go to rour breeding queen and take enough of her newly hatched larve to rear enough queen cells from to supply each one of your diseased queenless colonies with a ripe queen cell or virgin just hatched. These are to be introduced to your diseased colonies on the twentieth day after you have removed their old queen, and not one hour sooner, for upon this rery point your whole success depends; for your young queen must not commence to lay until three or four days after the last of the old brood is hatched, or twenty-seven days from the time you remore the old queen. If you are rery careful about this matter of time between the last of the old brood hatching and the young queen commencing to lay, you will find the bees will clean out their breeding combs for this young queen, so that she will fill them with ats fine healthy brood as a hive ever contained. This I have seen in several hundred hives, and have never seen a cell of the disease in a hive after being treated as above described.

It is not necessary to remove any of the combs or honey from the diseasul colony; neither is it necessary to disinfect anything about the hive. Simply remove the old queen, and be sure the young queen does not commence to lay until three or four days after the old brood is all hatched. This treatment with young Italian queens is a perfect wre for black brood.

In regard to those old queens that were formerly in your old hives. I think it best to kill them when you first take them from their colonies-not that the queen is responsible for the disease, for I am sure she is not; but a young Italian queen that has lreen realred from a choice honey-gathering strain is worth so much more to you that I (an not adrise saving these old queens.

I have experimented along this line considerably, and found, after the colony hats been without a queen twenty-seven days, as above directed, it will usually be saffe to give them one of these old queens, and the cure will be the same. still, there have been exceptions, so I advise lilling them at once.

The essential point in the treatment is to allow several days to clapse after the emerenee of the last of the healthy brood before the queen begins to lay. 
There are several points in this treatment and its sucesseful appliation by Mr. Mlexander which may well clatum our attention. In the first place, the seales formed by the dried latrare of Enropean foul brood are less adhesive than are those formed when Amerian foul brood is present. It is therefore easier for the bees to cheall ont the cells, and in most cases, alt any rate, a stronge colony would do this. This is one point, then, in favor of the Alexanter treatment of European foul brook.

Mr. Alexinder"s appiary is located in a portion of New York State (I)elanson, seheneetady Comnty) where European foul hrood hats bean prevalent for several vears. It is a matter of common obsersattion that this disease becomes less virulent in any given locality within a few years, and it is rery probable that this plan might be successful in Mr. Alexamler's apiary and not in localities where the disease is just appearing. At any rate, it is monwe to advocate its use in new regions when there is an established remedy-the shaking method.

The hives used hy Mr. Alexander seem to me to have a decided bearing on this subject. They are several inches shorter than the Langstroth hive, and, as a result, in the spring, when European foul brood usually appears, there is not a large supply of honey on hand. This, taken into consideration with the fact that very little honev comes in before August 1 in that locality, is very significant. The hive is not full of infected honey, and consequently when the bees clean out the combs they get all the infected material present. That this method would be snceessful in a moderate-sized hive-e. g.., a 10-frame Langstroth-may well be doubted, for in the wentyseren days during which the colony is left queenless many colls containing contaminated honey would be left untouched. Either we must adrocate rery small hives or advise against the Alexander method ats a enre.

The New York inspectors say that the publication of the Alexander plan has been a great detriment to bee keepers.

Mr. Frisck. I visited a yard last year where there were 2.2 infected colonies. The owner wished to save some new drawn-out combs that were on hives free from the disease. Is an experintent we noed fomndation with half of the colonies and in the others we put the new comb.s. Eleven had to be treated again, while the others, right in the same rard, did not. You can kill the germs in the honey. bnt von have to boil it until it is as black as molasses to do it.

Mr. Louss ficnom, (Texas). I do not know that I cam say much about treatment in Texas. We do not rely on the shaking treatment at all. Whenerer we have had fonl brood we have tried something as radical as conlel be practiced-that is, the burning of the diseased colonies. There is one trouble that we have here in shaking 
the bees. and that is that if we treat the bees during the honey flow there is so much danger of shaking out the honey and starting the disease again in that way. The other thing with which we have to contend is robbing. During a honey flow there is a good deal of inside robling almost all the time. Until we find something that is ab-olutely sure and absolutely a good thing we shall resort to the burning of colonies whenerer we find them infected. The way we use the fire treatment is to inspect the yards and then toward evening we dig a pit about 10 feet wide. according to the number of colonies to be treated. and build a brush fire. $\mathrm{B} y$ the time we have that burning well we go to the colonies that are to be " treated " and ure sulphur in a smoker. The entrance is smoked a little. and this kills all the bees. Tre go from one colony to another to kill the bees. to keep them from leaving the hives in handling: we know that no live bees can escape from those colonies. Te remore the combs and burn them. then the bottom boards and the corers are treated orer the flames. The hive bodies are stacked on a single bottom board. and from a small can of kerosene we pour just a little oil from the top down the sides: by throwing in some dry grass or anything of that kind, which has been lighted first. the fire will start at the bottom and the hive bodies will act as a chimner. In that way we scorch the hive bodies for a few minutes. As soon as these have been scorched sufficiently we close up the top with a bottom board or cover and close the entrance of the hive with earth; then we leave them for a little while for what we call " steaming."

Mr. Axpersox. Is there any way of safely detecting American foul brood before the cells are broken, and how long is it after it is sealed before the cap is broken? That is a question I have been discussing at home. and I would like to know if there is a way that it can be detected. For instance, if you have not treated a colony successfully. or suppose American foul brood has been in your locality and you are waiting for it. can you catch it before all the larra are exposed?

If there are only two or three diseased cells in a colony and if you cut those out. will the disease go any farther? I have read that if the cell cappings are broken and rou take out those particular cells rou will nerer see the disease again in that colony. I have heard an inspector say that he ean tell the disease in his own apiary. He claims that there is a way to tell it before the capping is broken, and he says he can take away the disease then and it will not reappear. I linow he can. hecause he has proved it. He ean tell where foul brood is before he can actually see it. He further says that the larvar are killed. but do not show it for forty-two dars afterwards. Now. I want to know if anyone else has found such to be the case.

Doctor Pnillips. I think his record stands alone. 
Mr. Ixperson. I know this: If you cut this foul hrood out hefore there is another exposure, ron won't get it in that colony unless it earried from somewhere else. I have proved that.

Doctor Prumblrs. As far as the forty-two days time is concerned. I have no faith in it. because in most eases inside of forty-two daythe colony wonld be dead. I have seen that demonstrated.

Mr. IIotwkmp. I might ask how early can the disease be discovered?

Doctor Pundaps. Not sooner than the ropiness of the larva be comes evident. I never saw a sample of diseased brood from Texas, but, assmming for the moment that the conditions in this State are similar to those in California. the method deseribed in the East is not going to work in Texas. It will work where the disease is not virulent. The same thing holds true for European foul brood. Where it has existed for five years it is easily treated, and the Alexander treatment is sometimes successful, but it is not when the disease first appears in a locality. As you know, European foul brool started in New York and is spreading to the Yermont line. You will find a great difference in the type of disease in schoharie Comty and on the Vermont line. The same thing seems to hold in a different way for the American foul brood. The disease is much more easy to combat in the East than in the West. I visited California this summer. Inspectors there have proved to their satisfaction that Eastern methods are not satisfactory, and they told me that it is necessary to burn out the hives. Mr. Smith does not burn his hives, and the inspector in New York does not burn hives; they insist, however, that no honey and no wax cells remain in the hives and that the hives be clean. That does not prove satisfactory in California. We know that this one disease is a very different proposition under different climatic conditions, and in discussing treatment it is necessary to bring out this point. In discussing treatment in bee journals writers forget or do not realize that the plans which they atrocate may not do in different places. As Mr. Parker said in his paper, the eastern treatment will cure nine-tenths. but the other tenth has to be taken care of. The disease seems to be much more virulent in the western part of the United States than in the easterin part.

Mr. L. Schold. ()ur conditions are the same here as in ('alifornia, I am sure. We have tried some of the shaking treatments, but they were mnsatisfactory. On accomt of the eharacter of the disease here, we think we are on the safe side in using the burning method until we can find something better. While Mr. smith and others gave their mothod of shaking the bees. I wish to put the guestion whether these treatments would work west of the Mississippi River. and that is why we have been practicing such radical measures here. Mr brother, 
who is here from the Agricultural and Mechanical College of Bryan. Tex. working for Professor Conradi, has been conducting experiments on this shaking treatment, and yon might get him to tell you something alout it.

Mr. Erivest Achond ('Texas). I am glad to be called upon, becante I have been paying clo-e attention to the shaking treatment, and as soon as Mr. J. Q. Smith mentioned his methos of shaking but once. I thought surely he is dealing with different conditions or it must have been an accident that he succeeded. My work has been mo-tly in the northern part of the State. but in one case I hat some work in the central part. I thought I would try some experiments. We tried shaking once. but it would not work: the disease appeared just as badly as ever. The tried shaking twice: that worked better. -o that shows that shaking once does not work here. I have tried many other experiments, and am still on the go. but this is the only point I want to bring out. Shaking once is not sucessful in Texas, and I don t think it ever will be. I don"t see how Mr. Smith can be successful in treating. because the bees gorge themselves with honey. Down here. as soon as you open a hive the bees will run to the cells and. consequently, shaking once would not work: and, as my brother saicl. there is always some honey taken up and the bees carry it into the new hive.

Mr. Juseac. Mr. Smith's plan is satisfactory in Colorado. We shake our bees there. but we smoke them a little bit and we shake only when a honey flow is on. The honey will sometimes drip on the wings of the bees. but it is rery seldom that foul brook starts again. I have been an inspector there for a number of years, and the general way is to shake the bees hard. We shake them a little bit differently. We put paper down and we shake when the honey flow is on and we save nearly all the brood-that is. the healthy brood--and let it stay twenty-one days. The reason for letting it stay so long is be(ause there is honey around and the bees hatching out will use it. Yot only do the inspector's instruct that shaking be practiced. but the state association has issued pamphlets, in which this treatment is explained, to be given by the inspector to each man who has foul brood.

Mr. D. C. Mnum (Uralde County. Tex.). In our locality we are governerl by conclitions. If the conclitions are not farorable for shaking. we burn the bees. frames. and all. If the conditions are farolable, shaking is all right. Last May I shook five colonies in one apiary for experiment. and week before last I went there and they were all right. but honer was not coming in fast.

I wish to speak of another thing. In this apiary I watched especially to see if there was any disease of the unsealed brood and I 
found none. Two reats ago I found the disease both in the sealent and minsealed brood, and the question comes up: Halve we both dis-

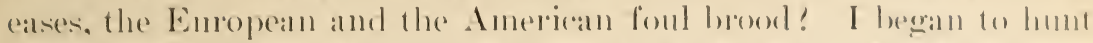
for another disease attalching sealed brood, and I foumd it that year: but I looked further, and in 6.5 colonies which I shook off lats -pring ron conld not find discase in any unsealed brookl. Latst fall a rear ago I went to one aptary that had several colonies in which the sealed hroed was discatsed. I told the family what they combl do. I sild: "You will eithere have to fight this disease and take calere of the colonies throngh the winter or yon can horn them wp." I will sily they were not bee keepers, and they said just to bum mp everything. I agreed to this. hut satid that there were two rolonies in the apiary that had only a few rells diseased, and I would experinent on them-that I womld talie them moled my own management. I burned the rest. but I kept those two colonies mutil this spring. Thi -pring they beame weak and I set one colony on top of the other. Last week I went back there, althomgh I had examined them some time ano, and they had starved to death.

(One shaking. I an sure, will do moler favorable conclitions. but if the bees are not gathering honey, I woukd not atrise shaking.

MEDICATION.

Mr. D.spaxt. Has anyone ever tried feeciing medieated simp? The reason I atk the question is because some people sueceed with drilg:.

Mr. Surtur. Mr. Reynolds was the first man in Illinois who inported Italian queens. He said that after foul breod got into his bees and destroyed them he heard of a remedy that condel be obtaineri at the drong stores. and the next time he transferred his bees he need this and he had good luck with them.

Mr. D.m.sx. After shaking them?

Mr. Surru. Yes. sir: and he ordered some of this drog from si Lonis just a short time ago. He said he was going to feed it to the bees next spring for fear they would develop the diseatse again.

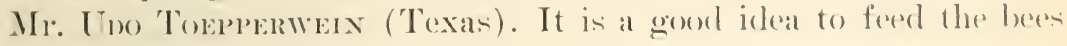
slgar and naphthol beta.

Mr. Atches. As Mr. Scholl has already stated, I don't believe treatment will eradicate foml hood in 'Texas. I have seen a fow people that have experimented this season in shaking bees. We hare never been able to determine results in shaking in one season. I have hat the disease disappear in the smmmer and fall and the next reall the colonies would be diseased again. Another point, in Texas bees are too cheap to treat. We can bum them and buy other colonies to replace them with less expense. 
PICKLE BROOD.

Mr. Surth. Is there anyone present whose bees have been suffering from pickle hrood?

Mr. D.nmxt. Mine have, and I used oil of eucalyptus. I thought I had foul brood and I afterwards discovered that it was pickle hrood. About every four days I fed some oil of encalyptus and in three weeks there was no trace of the disease.

Doctor P'musn's. Trould not that disease have disappeared without the nise of druges?

Mr. DAnıx. I doubt it. I asked another bee keeper to try the same thing and the result was the same.

Doctor Phillips. We have no proof that pickle brood is at all infectious. Oil of eucalyptus is a disinfectant; therefore I was wondering what effect it had.

Mr. Honeknap. One of the members of the Missouri state Bee Keepers' Association. who was about 20 miles from St. Louis. asked me to come orer and help with his bees. He said last spring that his bees were in a terrible condition; he was rery busy and did not know what to do. A good many of the colonies were in bad condition. He put a tablespoonful of carbolic acid in a quart of water and sprinkled his bees with this. He told me they were all well except two colonies. He said he did not look at them. I looked at them and they were clean. He told me that he had colonies that had gathered in five days a super full of honey. He had about 10 square miles of Spanish heather, but these colonies that had been affected did not make any surplus, so there must have been some disease.

Doctor Phillms. It might have been pickle brood. Pickle brood is sometimes pretty bad, but it will disappear.

EXPENSE OF TREATMENT.

Doctor Prillips. Is it so expensive to treat bees? How much does the colony lose by shaking during the honey flow?

Mr. Axomersox. We lose a honey crop. Take all that hrood away from a colony and all that remains is the live bees. For ten days there is no brood started to take the place of what has been remored.

Mr. Jrxist. It is altogether different in our country (Colorato). The shake bees. and they act just like a new swarm. I have had as - high as two or three swarms from those that have been shaken. if they were ordinarily good strong colonies. and I believe it will do just as well to shalie a colony during a honey flow as any time. It malies no difference.

I)octor Pnulus. That is the point I was about to mention. I know that in Colorado they sometimes shake bees whether there is disease or not, because they chaim the bees do better. You talk about 
shaking bees being a very expensive operation. but youl do not neod any hrool during the honey flow, and the time malies a grean difference.

Mr. York. There is one thing to be taken into ansideration. Base are worth less pere colong in Texas and california than in the biand

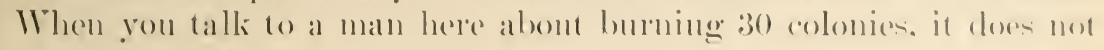
take all his bees.

D1. Prutcups. I do not know about 'Texas, hut I do know than farther west an eradication of a) colonies to many of the hee kerepertes of the Wes is not a serions proposition. The western bee kesperes nomal increase is more than his loss. so it is not like the losi to a small bee keeper.

Mr. Atruntr. In Texas we hardly erer find an apiary in which every colony has the discase: therefore, when we hurn the atlected colonies we have enough left to rebuild the apiary.

Mr. Roxkis. In considering this matter of bee disease and here inspection one sometimes wonders if the ideal inspector exists. It would sem that bee in-pector's are born, not made. The fact that a man knows bee disease and its treatment does not indicate that he is necessarily a good inspector. The most sucessful inspectors of whom I know are men who not only know bee disease thoronghly. but also have the ability to handle the bee keeper whose bees they are inspecting. The successful bee inspector. then, must first of all be able to diagnose the disease and know it moler all its varying conditions. Next, he must know its treatment and management meler every condition which maty arice; he munt know erery condition on which the snceess of the treatment depends. Then. last. but also of vital importance, he must be able to use tact in the handling of the men whom he is appointed to help. He must know from the appearance of a man and from the first words exchanged just how to proceed with that particular individual to secure the best results.

Let me add a word in defense of the inspectors. I know 14 of those in California personally, and among them are some very exceptional men. They are not all equally snceessful, althomgh I heliever they all know bee diseases thoroughly. but among the entire mumber I do not know a single man who is serving as bee inspedor merely. for the money he receives for the work. Let we give areelit to whom credit is due. These men are doing good work, and it is lhomeh these men that the bee keepers most look for the suppresion of hee di-eases under the present sy-tem. Give them pour support and encomagement, but never under any consideration eriticize them in public in a way which would interfere with the work on bee disea-e. The laws provide for the removal of an incompetent mane and if a man is not competent to serve as an inspector let him be remored and 
a man put in his place who is competent. liut under no circumstance subject an inspector to the criticion of the bee keepers of the community or of the bee-keeping press. This is mwise. for it gives the public a prejudice against insection rather than again-t the individual in-pector. while those few deserving of censure are perhaps una ffected.

BOILING HONEY FROM IMSEASEI) COLONIES.

Mr. Metr. Mr. France has said that you can not kill the germs in homer until you boil and boil until the life is all out.

Mr. Riskix. All you have to do is to make a hot fire and the honey will boil. Of course you have got to boil it sufficiently long to kill the germs.

Mr. Metri. How large is the tank reservoir?

Mr. R.uxisx. Big enough to hold your combs: as Abraham Lincoln said of your legs. they must be long enough to reach the gromnd. 'The tank used by one bee keeper is 6 feet square and $t$ feet high. and you would be surprised to see the amount it will take care of.

Mr. Theis (Mis.). Are the frames destroyed then?

Mr. Raxkix. Tes; we never use any secondhand frames.

Mr. J. A. Rotse (Mo.). I would like to ask if that water does not get too thick?

Mr. Raxkix. Not at all.

Mr. Rocse. How do you get rid of the honey? I tried that plan and found that honey and wax hung with the frames until they did not look like frames.

Mr. Atchler. Mr. Rankin's treatment is similar to ons except that we burn. The labor for digoing ditches is very cheap). It would only cost us \$.s to get ten ditches, and in each ditch we can burn 30 or to colonies. Our treatment is something like your California treatment, except that it is not so complicated and is less work.

Mr. Ruxisx. That is another phase of the proposition. Conditions are different in that also. In California you can not hire a man to do the work for less than \$so per month.

Doctor Philums. Te have gone over the subject of treatment thoromglily. and I think all persons here have arrived at about the same conclusion; that is, that it will not do for a man who has a few colonies in one part of the Enited states to write to om bee jommals and tell us all what to do. We want to know what he is talking about. The rast majority of the men who wite to-rlay know nothing about the varving conditions. What wiil work in one little comnty in the East will not work in the Mest. and vice versa. the methods of the West will not work in the East. Filppose that Mr. sinoll should sit down here and tell everybody in the Enited states to hum their bees. 
Treatment depends npon the locality. Locality is an important fatcose. but what we have to do is to find ont in what respere the locality is diflerent. Whether it is in climatic anditions of in the conditions of the honey flow. We are in just as mull ignolance when

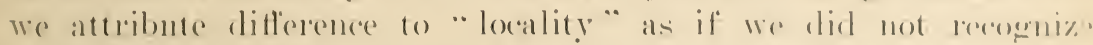
any difference. We must get down to the point where we know the individnal fastors involved. I anticipate that when some of the

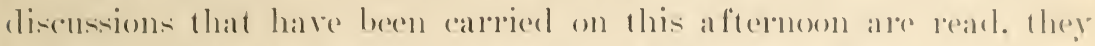
will open the eyes of some people that think they have had some experience with disease. We have men from the Eastand West who have different conditions to contend with. That is one reason why I hare been in faror of an inspectors mesting. Here we get on an common gromel. ('onditions from diflerent parts of the cointry are dirensered in a way that yon can not obtain pratedically in any other" way.

I have coppes here of the laws relating to foul-hrood inspection now in forec. Some of these are defieient and others have valuable points which onght to be brought out. It seems that the best thing to do is to put a copy of them in the hands of every man who is an inspertor. with a list of questions taking mp the points which are covered by the laws. and ask each one to express an opinion concerning them. Then all that expert testimony shonld be collected and put on recorel, so that people interested in future changes of legislation may reacl it. If there is anyone here that would snggest how this suljeget should be handled, I shomld like to heal from him.

Ifter some dincussion, it was finally decided that the IBurean of Entomology be asked to prepare a list of (questions to be sent to all the inspector's. (The future action in regand to this is discussed in the preface).

Mr. France then read the following paper:

\section{THE HISTORY OF BEE DISEASE INSPECTION IN WISCONSIN.}

IYY X. E. Fouxe,

Imspertor of tpiaries for llisermmint.

From 1870 to $18 s$ f bee keeping was one of the profitable agricul-

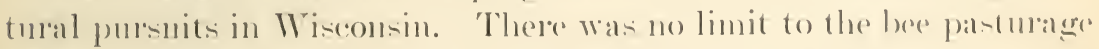
of white clovere besides miles of haswood timber and large areas of wild flowers. (omb honey in all kincle of packiages oold for from 2.5

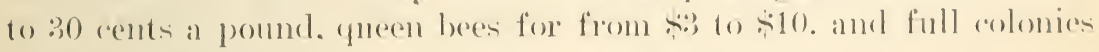
were from $\$ 1011$ ).

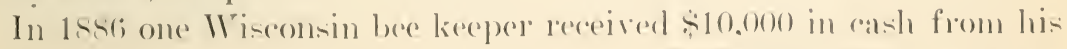
1.400 colonies, and started the first bank of Jeflerson. Wis. Another apiary of 250 (oolonies yielded in 1852 29.000 pounds of homey; in 
1 sitt :30.000 pounds. and in 18s6; with 240 colonies, it yielded 25.000 pommis. This hee keepere also becane a partner in a bank. Anothere apialy of 175 colonies in 1886 vielded 32.7 .25 pounds of honey and in 1s!) 1 the bees were all dead with foul brood. Another apiary of 200 colonies in 1900 yielded 21.000 pounds of honey. but in 1904 all the bees were dead. Inother apiary of 50 colonies in 15.97 vielded $: . .000$ pounds. but in 1900 all the bees were dead. Another apiary of 26 colonies in 15.99 yielded 2.500 ponuds of honey and in 1901 all the bees were clearl. Thus I could enumerate a pageful of similar sad result: of foul brood.

About this time the State Bee Keepers" Association roted to delegate to the president of the association the securing of proper law for the eradication of this disease. With little help from the bee keepers. he had to see his efforts turned down. Two years later I was delesated as before. but without the personal help of our members the bill was ridiculed and lost. Thile before the legislative committee I learned better what must be done, and two vears later a committee of all the officers of the State Bee Keepers Association was delegated to act. with the promise that each State member would do his part. The committee got figures of facts about Trisconsin bee keeping and furrished each association member with copies of the same. with the request that each one see personally the member of the legislature from his district. Many members did as requested and our entire committee appeared before the first legislative committee and madr good progress. When the last State committee on State appropriations was to consider our bill I was alone. Several other bills calling for aid were turned down before I had a hearing. I gave the committee these facts to consider: (1) There are 10.53.5 farms in Wisconsin, having 106,090 colonies of bees, which produce in one year. 2.675.100 pounds of honey. (2) There are more than wice as many pounds of honey produced each year in IVisconsin as there are head of cattle or sheep. (3) One year's honey crop in Wi-consin womld load 13 freight (ars. or if placed all in full-weight pound section boxes, touching ach other. a sweet honey walk $t_{1}^{1}$ inches wirle would reach $181 \frac{1}{4}$ miles-more than the distance across the state. (4) The valuation of Wisconsin bees and products amounts each rear to more than the appropriation made by the State for several state institutions. (o) The state Horticultulal Society recoives over ten times more aid from the state than the bees do. ret orel thee rimes as many pounds of honey as bushels of apples are produced. (6) Orele 10.o()0 Misconsin taxpayers and roters who send representatives to lhe legislature are bee keepers and ati to be reasonably protected by lat 10 to silve the bees.

Iftel I was excused from the committee room the committee roted mamimomsly to recommend the bill for passage. It soon became it 
latw, and an inspector was appointed in the person of the writer. ()wing to false statements in the papers regarding the new oflice createrl. I met with all kinds of difliculties, such ats being met at the gate with a shotgun and bull dog. It other times I was ordered from the premises with a pitchfork raised over my head, but aach time I quietly explained why I was there, what I intended to do, and read the latw. "or refuse to allow the inspector of appiaries to insperet stech aptary, honey, or appliances shall be fined not lese than tivo nor mere than $\$ 100$, or be imprisoned in the eomnty jail not less than one month nor mere than two months." Before going away I sal the apiary eleaned up in proper shape, the owner well pleased, and was rexperted. whenered in that part of the state, to call and fore them. Now, when I am called to inspect or treat an apiary the bee kereper is grad to leare his other work and meet me at the train. take me to the desired place. help me, and even take his team to aid inspecting the neighborhood. Everyone who has once been through the treating process will nerer need state aid again. but will take care of his own bees in the future.

Feveral times the disease has been almost stamped ont of Trisconsin. when newly imported cases have appeared, and before owners know what the trouble is several apiaries are affected. I hope that soon crery State will have laws on diseases of bees, and that no one can sell or ship bees without a health certificate similar to that required for farm stock in IVisconsin. 

liexander treatment for hee diseases............................ tittin

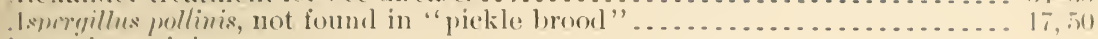

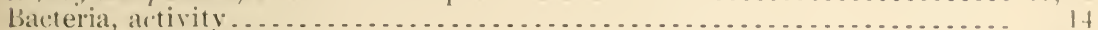

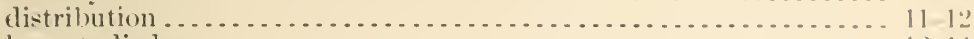

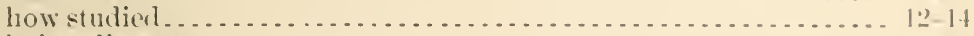

in bee diseases. . . . . . . . . . . . . . . . . . . . . .

nature ............................................... 10.11

nompathogenic ......................................... 14

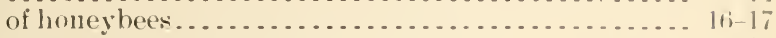

pathogenie............................................ 14

of honeybees................................. 17

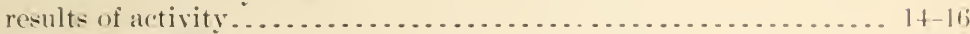

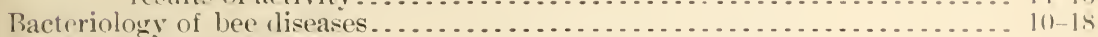

Bucillus .1 (B. mesentericus?), description by White quoted..............

on healthy adult honeybees and comb....... it

perhaps mistaken for $B$. aliei by Harrison ...... in th

Mackentie.. .8 35

al.ei, can not be identified by microscope alone.............. 12

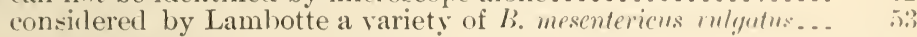

cultural characters ............................... $1,14,15$

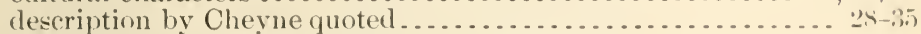

distribution in infecterl hive ............................... 17

present in European foul brood ....................... 16

so-called "black brood" ..... . . . . . . . . . . . 15, 50

$B$, in pollen and intestine of healthy honeybees ................ 16

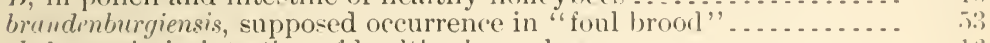

cholerit suis, in intestine of healthy honeybee . . . . . . . . . . . . .

cloreat, in intestine of healthy honeybee ......................

coli crommunis, cultural characters ............................ 13,14

in intestine of healthy honeybee.............. 16

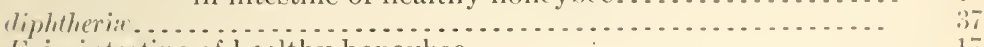

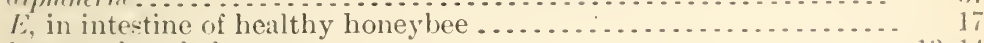

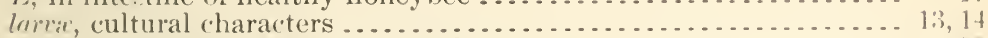

description by White quoted............................. 52

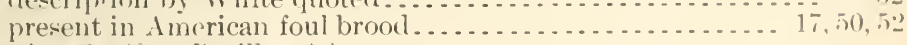

mesenterirus? (See Bucillus A.)

mesentericus vulgutus. ............................... is

considered by Lambotte caus of "foul hrowl", - . ,?

milii, no such organism found in so-called "black hrood" ........ 1., .5 (1

sulugnstricus, in intestine of liealthy honeybee ............... 17

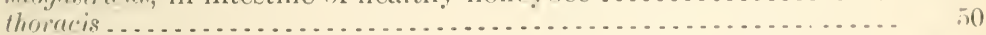

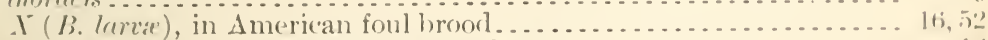

Burlerimin rugmeus, in combs of healthy honerbres . . . . . . . . . . . . . . . .

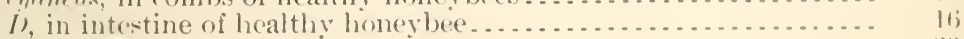

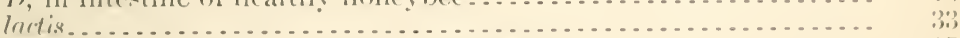

myroiles, in intestine of healthy honeybe .................... 17

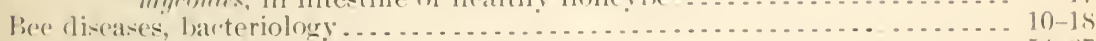

effect of climate on virulence ........................

(xpense of treatment . . . . . . . .

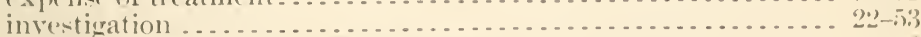

publications of Burrau of Entomology - . . . . . . . . . . . . .

treatment . . . . . . . . . . . . . . .

Bees, healthy arlult, bacteria found externally . . . . . . . . . 
Bertranil, Eelwcrd, regarding determination of Bucillus alvei by Cowan and

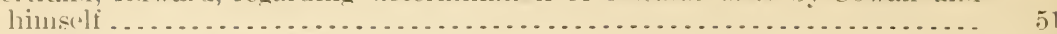

"Black broorl," Bucillus wilii not found ............................ 15

=European foul brood ............................ 17

no snch dlisease .................................... 21

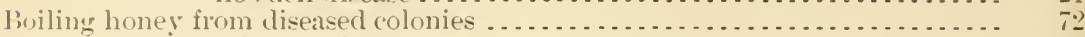

treatiment for bee diseases . . . . . . . . . . . . . . . . . . . . . . . 60-61

Burning, for destroying hee diseases . . . . . . . . . . . . . . . . . . . . . . . . . . 58,60

in Texas ....................... $67-69$

("irbolic acid, against "pickle brood" ...............................

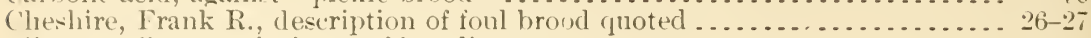

C'limate, effect on virulence of bee diseases . . . . . . . . . . .

Combs, of healthy apiary, bacteria found .......................... 16

Cowan, Thonas li illiam, attempted determination of Bacillus alrei with nicro-

scope alone .............................................. $50-51$

(ryptococcus alvearis, formerly considered cause of "foul brood" .......... 24-25

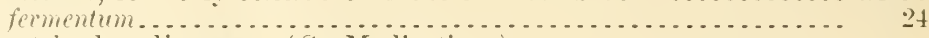

I)rug treatment for bee diseases. (See Medication.)

Eucalyptus oil, against "pickle brood" ........................... 70

Formaldehyde. (See Formalin.)

Formalin, use against bee diseases . . . . . . . . . . . . . . . . . . . . . . 58,62

Foul brood, American, application of term . . . . . . . . . . .

Bucillus larax present.......................... 17

can it be detected before cells are broken?......... $66-6 i$

description quoted from Phillips ................. 18-19

geographical distribution ................... 53-54

in California . . . . . . . . . . . . . .

on Pacific coast ........................... $57-59$

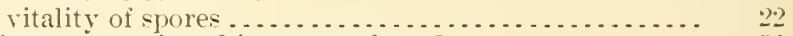

are both diseaces ever found in same colony?............. 53

comparison of American and European................. 20

European, application of term .......................... 16

Bucillus alcei present .......................... 1 i

description of Phillips quoted.................. 19

geographical distribution ....................... 19-20

in New York State ........................ . . 5 .5 56

spreal through infected honey .................................. 20,56

symptoms of two diseases confused by cheshire .............. $26-27$

France, N. E., paper, "The History of Bee Disease Inspection in Wisconsin" - 73-75

Geographical distribution, of American foul brood................. . . . . . . .

European foul brood..................... 19-20

Harrison, F. C., description of "Bacillus alvei" (Bacillus . 1 ?) quoted ........ . t3-4s

historical résumé of investigation of bee diseases quoteil .... 23-26

Honey, from healthy hive, usually sterile....................... 16

infection . . . . . . . . . .

Howard, W. R., work on bee direases............................. 15,50

Ichneumon apium mellificarium, formerly supposed cause of infectious beedisease. 24

Infection, in oraries of queen bees. . . . . . . . . . . . . . . . . . . . . . . 5i

is it carried to flowers? . . . . . . . . 21

of larve of honevbees . . . . . . . . . . .

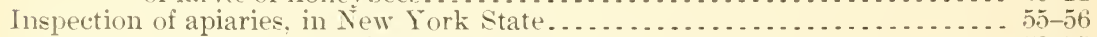

Wisconsin ............................

on Pacific coast . . . . . . . . . . . . . . . . . . . . . . . 5

inspectors of apiaries, appointment . . . . . . . . . . . . . . . . . $59.60,61-62$

organization ....................................... 10.54

Intestine of healthy honeybee, occurrence of bacteria.................. 16-17

fungi and yeats . . . . . . . . 16-17

Larve of healthy loneybee, usually sterile...................... 16

honeybees, infection............................... 20

Mackenzie, J. J., paper, "The Foul Brood Bacillus (B. alrei); its Vitality and

Developnent," quoterl ..................................... $36-42$

" Ir.Eny" treatment for foul-brood diseases ...................... $40-41,61-62$

Merlia for hacteriologieal work . . . . . . . . . . . . . . . . . . . . . . . . . . 12-13

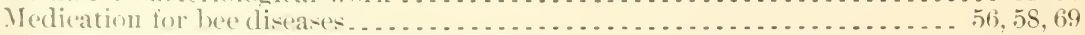

Mirromecus $($, in combs of healthy honeybees........................ 16

Moore, 1. A, investigation of brood diseases of bees.................. $51-52$ 
Naplethol beta, for boe diseases.

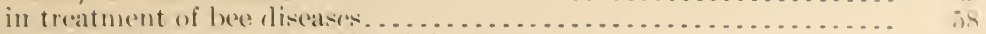

"New lork Be Disease." (Nir" Black brooil,")

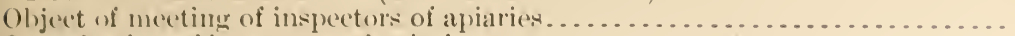

Organization of inspecturs of apiaries . . . . . . . . . . . . . . . . . . . . . .

Palse. (Ser l'aralysis.)

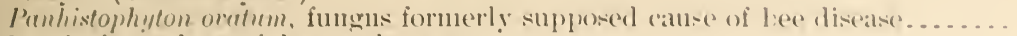

l'aralysis, no bacterial eanse known . . . . . . . . . . . . . . . . . . . . . .

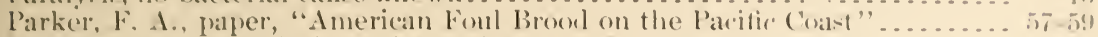

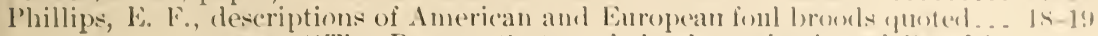
paper, "Tlee Present status of the Investigation of lice lis-

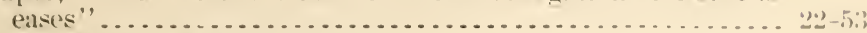

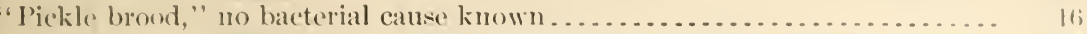
treatment .....................................

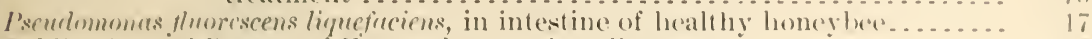

Publications of bureau of Eintomology on boe discases . . . . . . . . . . . . ... ...)

(2neen bees, wecurrence of bacteria . . . . . . . . . . . . . . . . . . . . . 21]

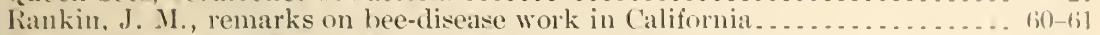

Replneening, as remedy for bee diseases...................

Root, E. R., rowarling Cowan's determination of burillus alvei in ()hio...... . 50)

Sacharomyces $F$, in intestine of healthy honevbee................... 17

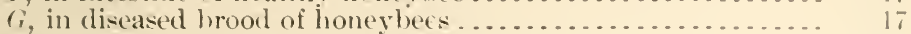

rosens, in combs of healthy honeybees................ iti

Schiracle, orierinator" of "Mckvoy" treatment for bee discases . . . . . . . . . . ti?

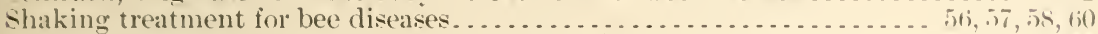

in Texas . . . . . . . . . . $67-69$

sprirorhate ap)is, supposed oceurrence in hee disease . . . . . . . . . . . . . 5:?

Stewart, Charles, paper, "Apiary Inspection in New York State" ......... 55-5t;

Treatinent of hee diseases . . . . . . . . . . . . . . . . . . . . . . . . . . . $61-73$

expense................................. $7(1)-72$

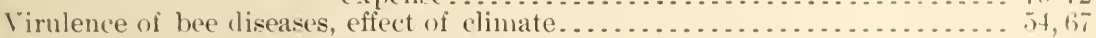

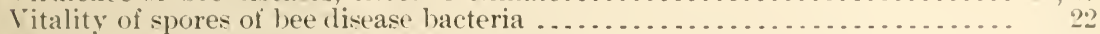

White, G. F., description of Bacillus $A$ (I) mesentericus !) quoted ..........

larrit quoted .......................... 5?

investigation of brood diseases of bees . . . . . . . . . . . . . . 51-5.2

paper, "The Bacteriology of Bee Diseases" ............. . . 10-1s summaries to Parts I and II and Conclusioms from Technical

Series, No. 14, Bureau of Entomology, quoted........... 16-1s 
